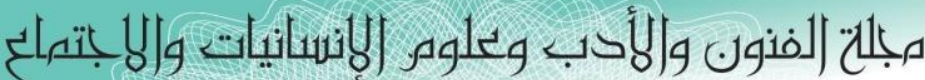

Journal of Arts, Literature, Humanities and Social Sciences

ISSN online: 2414 - 3383

ISSN print: 2616 - 3810

أيلول -سبتمبر 2019

العدد (43)

\title{
مستوى الثقة التنظيمية بمديرات المدارس الثانوية في مدينة أبها ومحافظة خميس مشيط" الميط
}

اعداد الباحثة: عبير بنت عبد الله بن علي خلبان القحطاني

قسم الإدارة والتخطيط التربوي / كلية العلوم الاجتماعية / جامعة الإمام محمد بن سعود الإسلامية

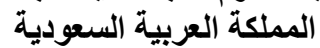

إثراف: د. هيلة بنت عبد الله الفايز

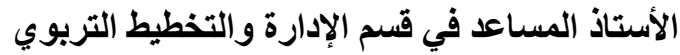

الملخص

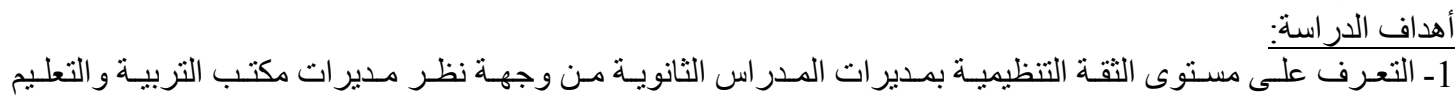

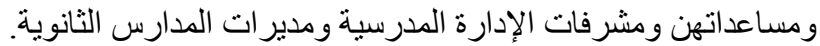

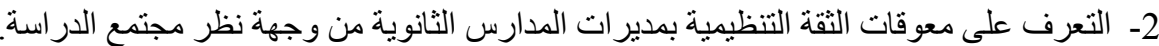

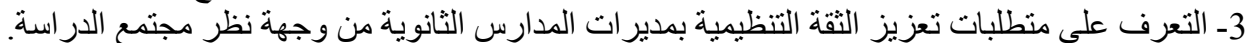

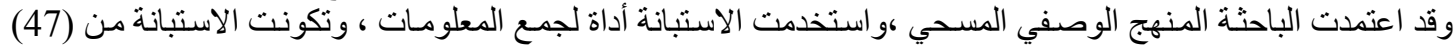

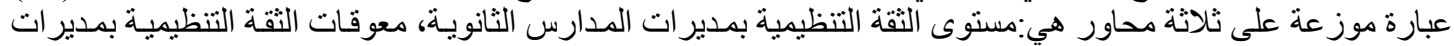

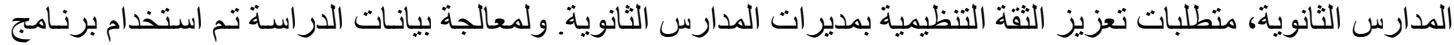

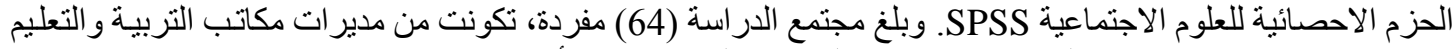

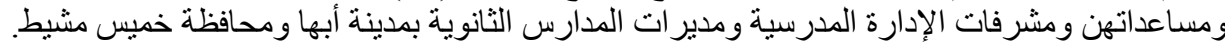

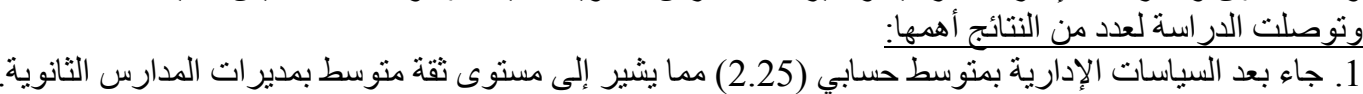

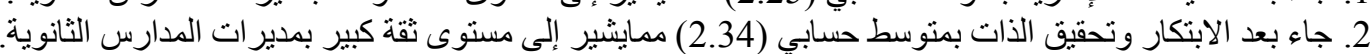

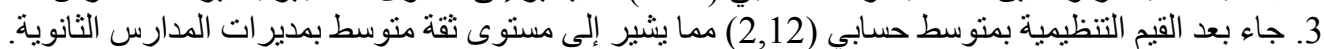

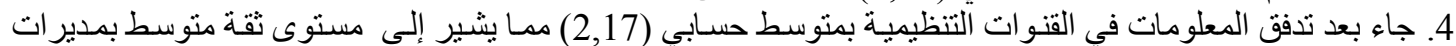

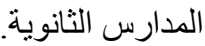

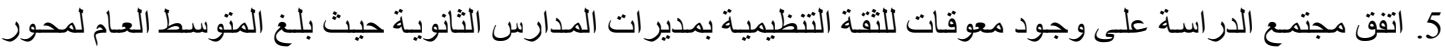

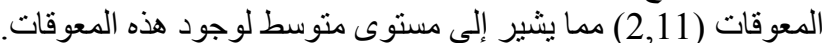

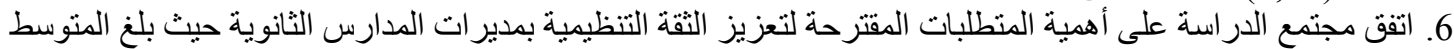

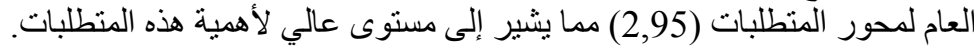

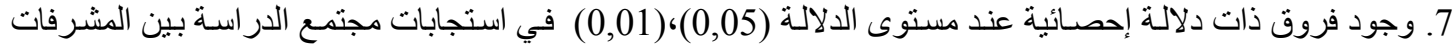
و المديرات في بعدي السياسات الإدارية وفرص الإنة الابتكار وتحقيق الذات لصالح الصاتح المديرات.

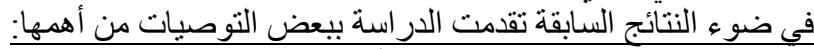

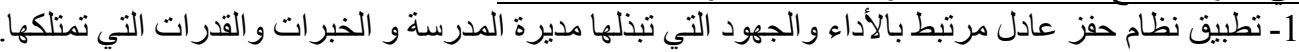

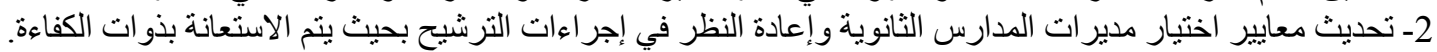

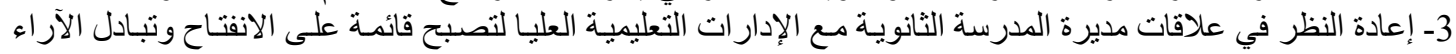

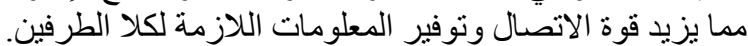

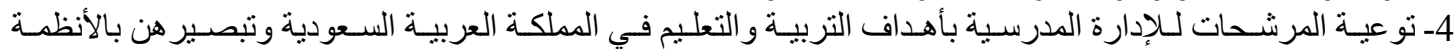

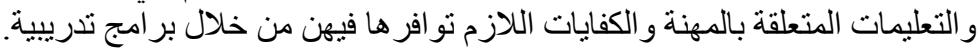

* بحث مكمل لنيل درجة الماجنتير في الإدارة و التخطيط التربوي. 


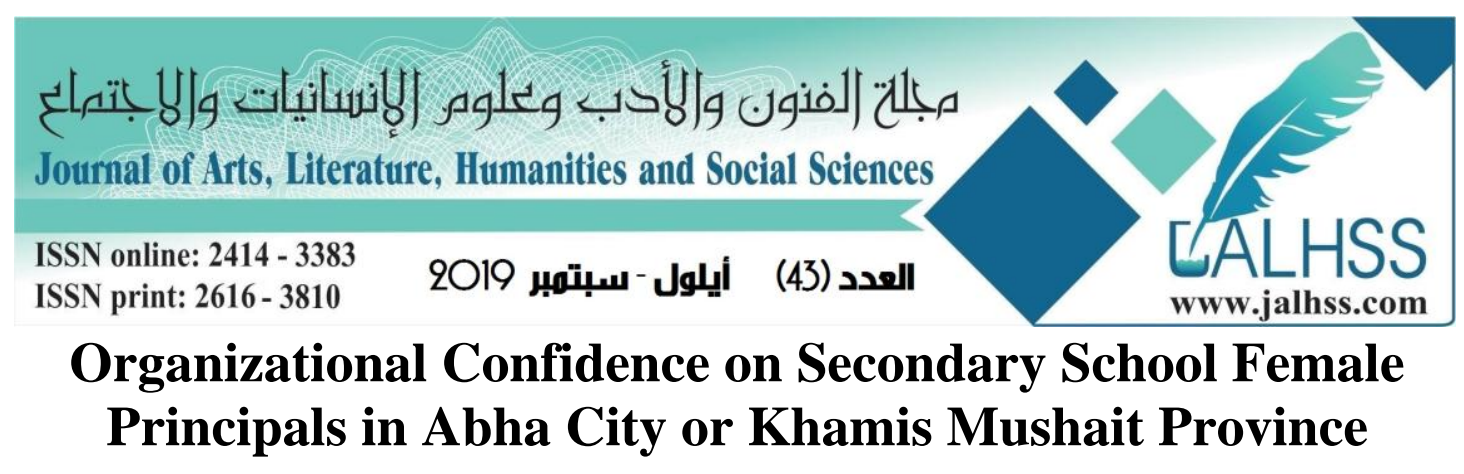

\author{
Prepared by: Student: ABEER ABDULLAH A. AL QAHTANI \\ Supervised by: Dr. HAILA ABDULLAH ALFAIZ
}

\begin{abstract}
Study Objectives:

1- Identifying the standard of organizational trust on secondary school female principals from viewpoint of the sample members

2- Counting the obstacles of the organizational trust on the secondary school female principal from the viewpoint of the sample members.

3- Knowing the requirements of enhancing the organizational trust on secondary school female principal from the viewpoint of the sample members.

Study Approach:

The researcher depended on descriptive approach and she used questionnaire as a tool for collecting information. The questionnaire consisted of (47) phrases distributed upon three themes, which are: the level of organizational trust on the secondary school female principals, obstacles of organizational trust on the secondary school female principals, requirements of enhancing organizational trust on the secondary school female principal. We have used the Statistical Package for Social Sciences. Study Sample consists of (64) subjects from Educational supervision female managers, educational supervision female assistant managers, school supervision female supervisors and secondary school female principals in Abha and Khamis Mushait. And the study has come up with a number of findings the most important among which are:

1- The dimension of administrative policies has shown an average of (2.25) which indicates medium trust on school female principals.

2- The dimension of creativity and self realization has shown an average of (2.34) which indicates a high trust on female principals of secondary schools.

3- The dimension of organizational values has shown an average of (2.12) which indicates a medium trust on female principals of secondary schools.

4- The dimension of information flow in organizational channels has shown an average of (2.17) which indicates a medium trust on female principals of secondary schools.

5- The individuals of the study sample have agreed upon the fact of existence of obstacles which encounter organizational trust on secondary school female principals, and the general average of the obstacles was (2.11) which indicates a medium level of the existence of such obstacles.

6- The sample members agreed upon importance of the requirements needed to enhance organizational trust and the general average for requirements them reached (2.95) which indicates high standard of the importance of these requirements.

7- There are differences of statistical significance at the significance level of (0.05) and (0.01) in the responses of the sample members among female supervisors and principals in relation to the dimensions of administrative polices, creativity opportunities and self realization for favor of the female principals.

In light of the results reached by the study, the researcher has proposed some recommendations the most important of which are:

1- Applying a fair incentive system related to quality and to the efforts exerted by the school female principal and the experiences and abilities she enjoys.

2- Updating the standards of selecting the secondary school female principals, and reconsidering the nomination procedures, and seeking advice of experts and specialized persons.

3- Reconsidering the relationships of the secondary school female principal with the senior managements to be based on openness and opinions exchange to enhance communication and provide necessary information for both parties.

4- Orienting the candidates nominated for school management about objectives of education in the Kingdom of Saudi Arabia, and educating them about the regulations and instructions as related to the profession, and the skills to be attained by them through training programs.
\end{abstract}




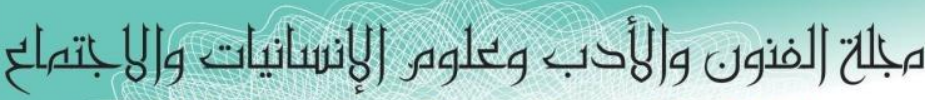
Journal of Arts, Literature, Humanities and Social Sciences

ISSN online: 2414 - 3383

ISSN print: 2616 - 3810

\section{العدد (43) ايلول - سبتمبر 2019}

\section{الفصل الأول \\ مدخل الدراسة}

1-1 مقدمة الدراسة

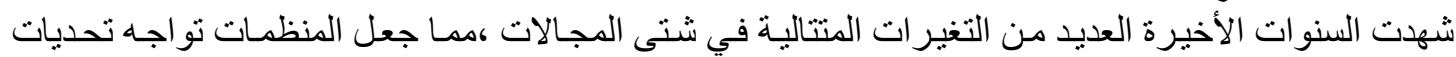

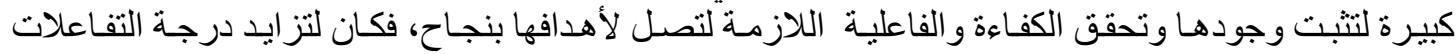
البشرية وتبادل المعلومات وشـمولية الفكر والجهد لحل المشكلات دور ا هامـا في الاهتمـام بالثقة كمحدد رئيسي فيسي

لنجاح العلاقات وتهيئة بيئة عمل تتسم بالا هتمام بالقيم التي تعد التقة التنظيمية من أبرز ها.

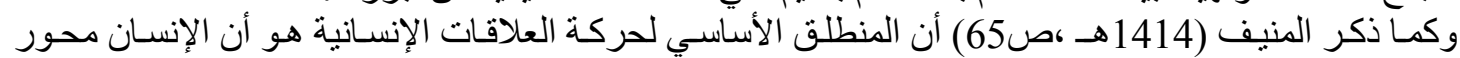

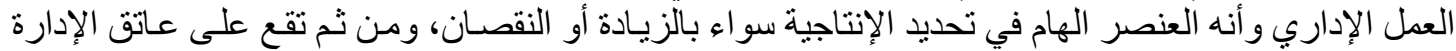

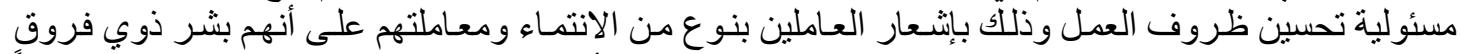

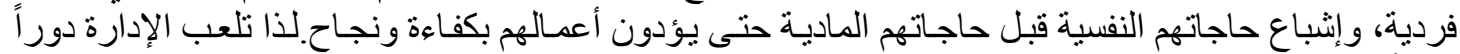

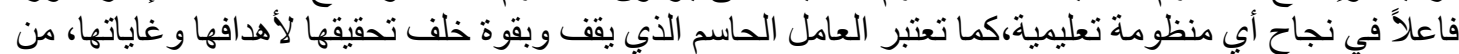
هنا تظهر الحاجة الملحة لتفعيل الجانب المادي و التقني وتكثيف التخطيط و التنظيم لتنمكن هذه المؤسسات التعليمية

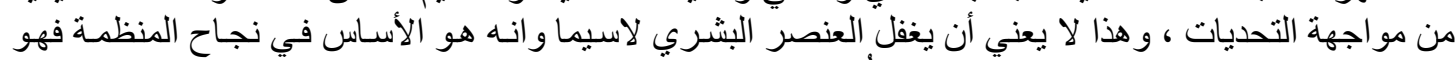

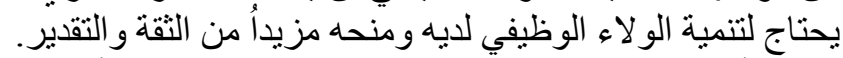

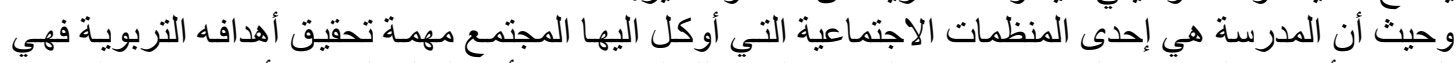

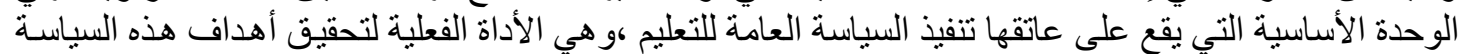

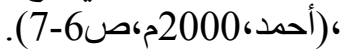

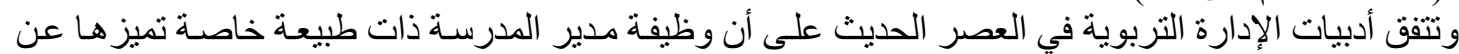

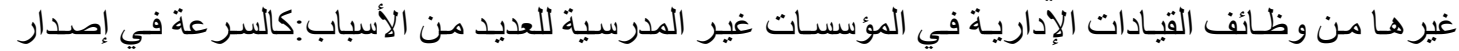

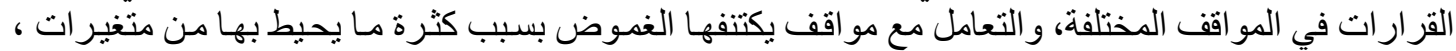

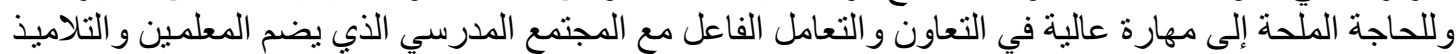

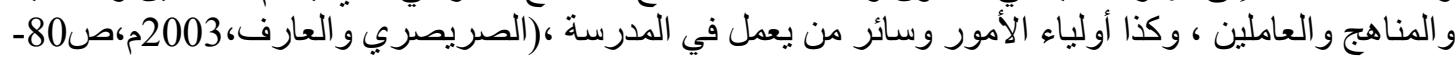

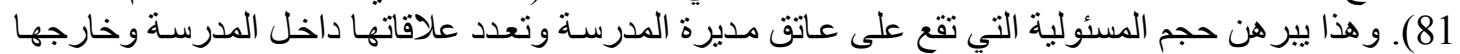

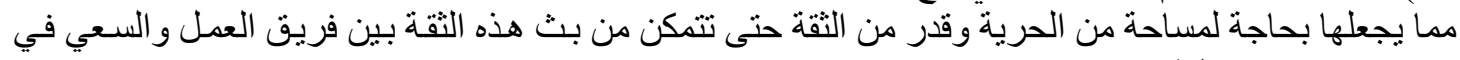

تحقيق فيادة ديمقر اطية.

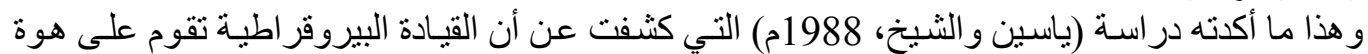

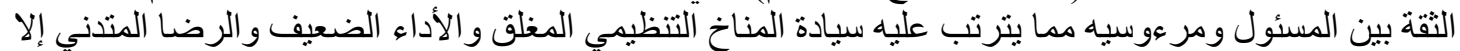

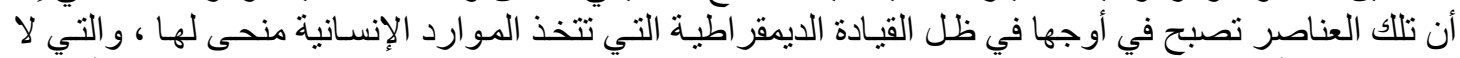

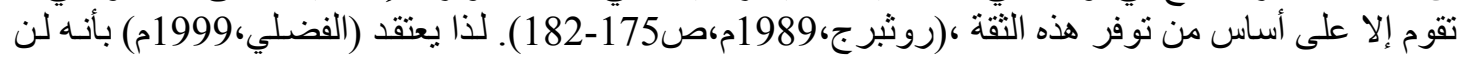

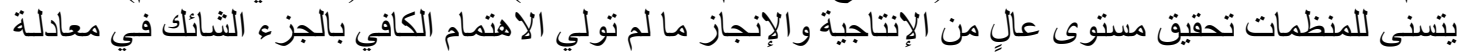

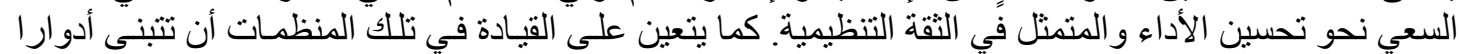

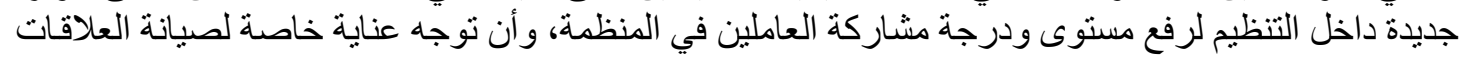

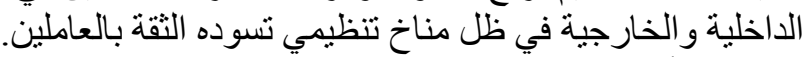

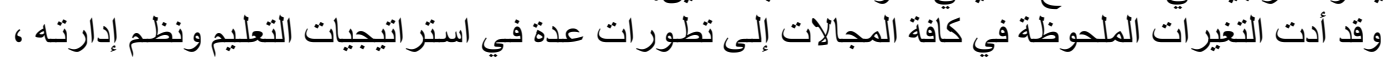

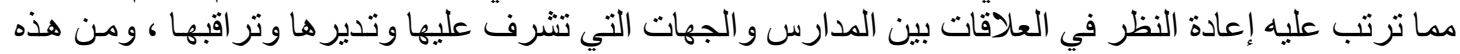

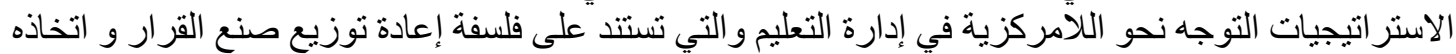

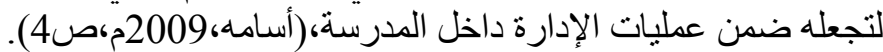

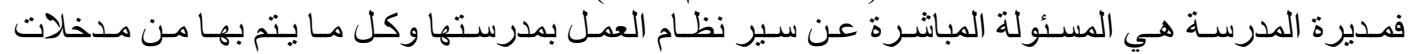

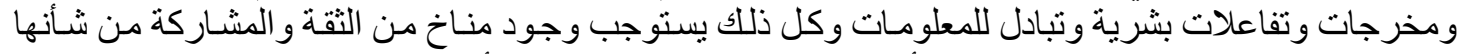

تحفيز مديرة المدرسة بشكل مستمر لتقديم أفضل ما لديها، وبالتالي تحقيق الأهداف التنظيمية بكفاءة. ومن هنا جاءت هذه الدراسة لتسهم في التعرف على مستوى الثقة التنظيمية بمديرات المدارس الثانوية. 
مبلحت (لفنون والأدب وعلوه الإنسانيات والب وبتهاع Journal of Arts, Literature, Humanities and Social Sciences

ISSN online: 2414 - 3383

ISSN print: 2616 - 3810

\section{العدد (43) ايلول - سبتهبر 2019}

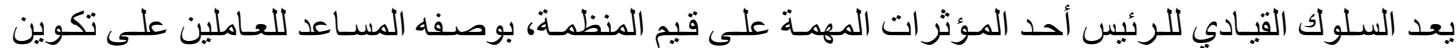

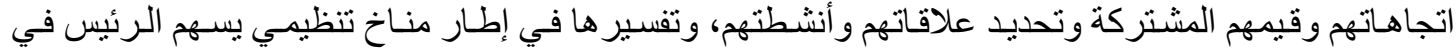

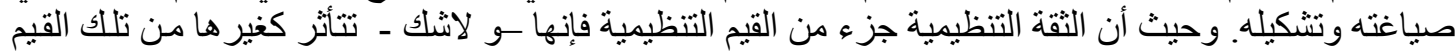

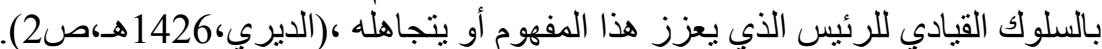

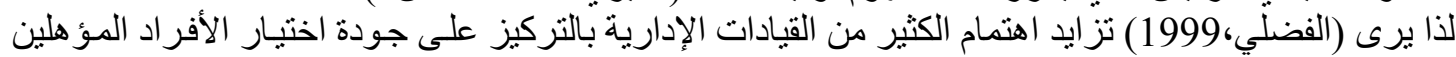

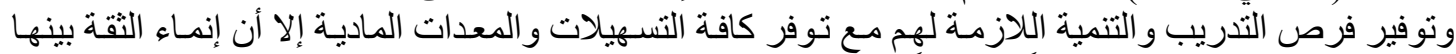

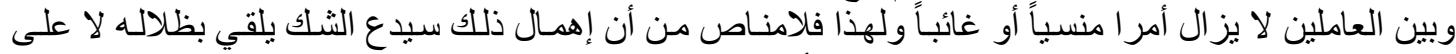

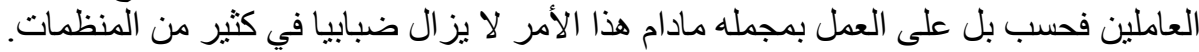

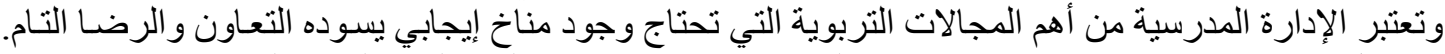

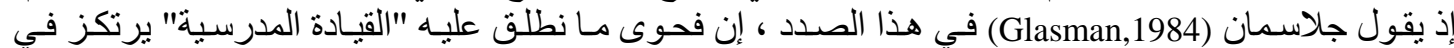

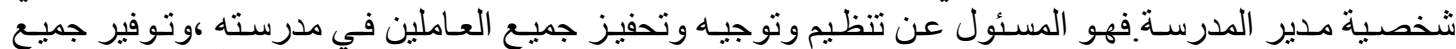

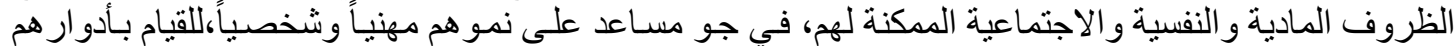

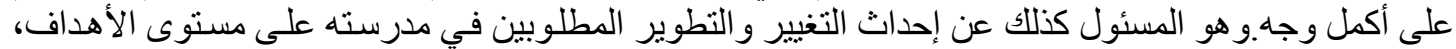

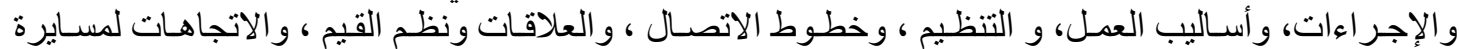

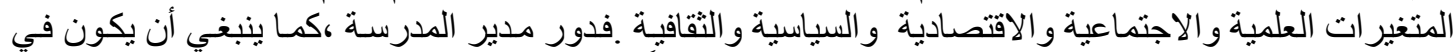

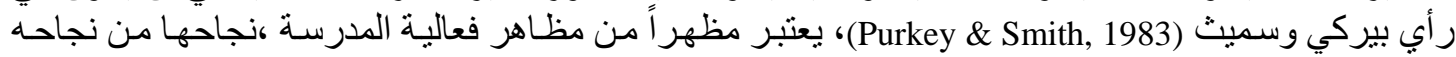

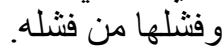

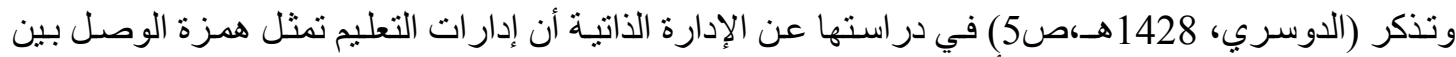

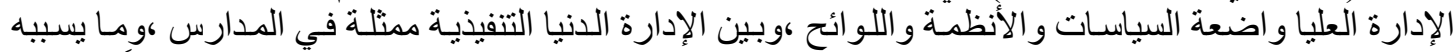

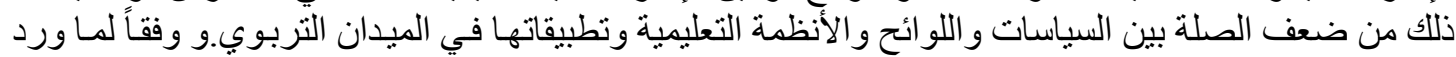

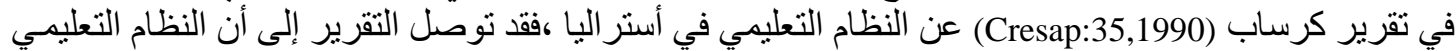

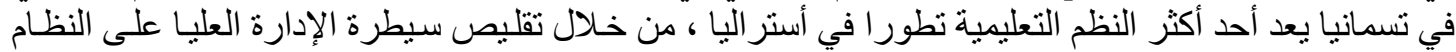

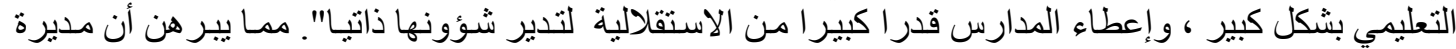

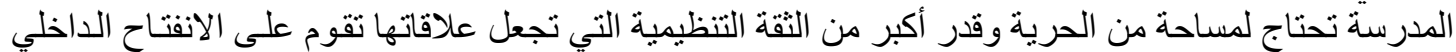
و الخارجي مع البيئة التنظيمية.

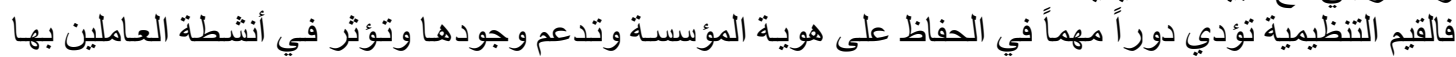

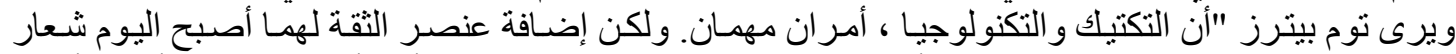

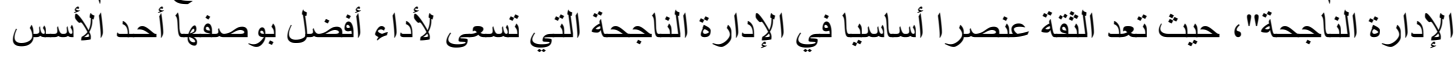

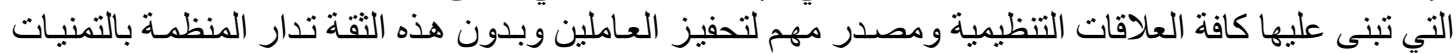

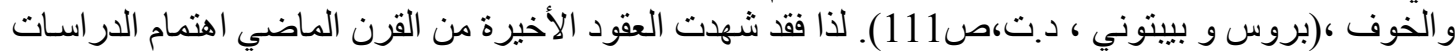

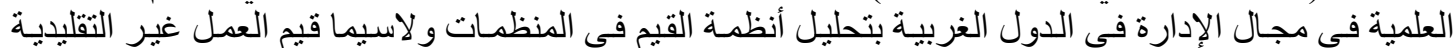

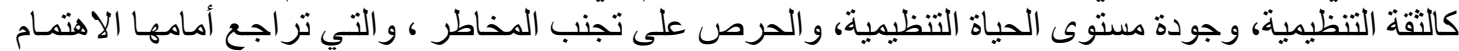

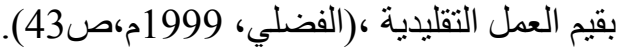

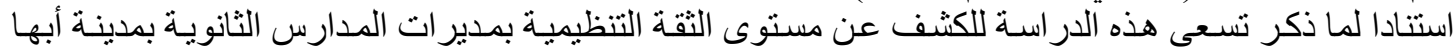

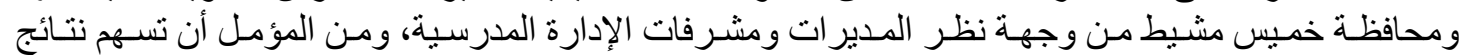

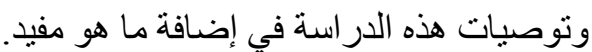

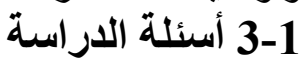

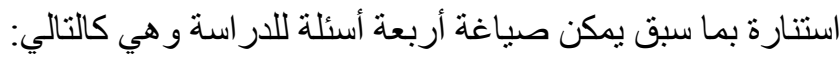

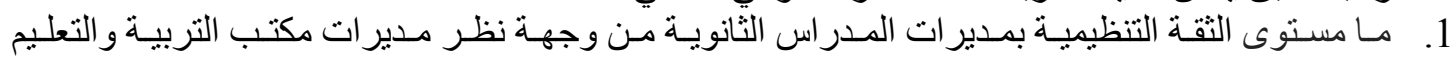
ومساعداتهن ومشرفات الإدارة المدرسية ومدير ات المداريز المدارس الثنانوية؛ 2. ما معوقات الثقة التنظيمية بمدير الإدار المدارس الثنانوية من وجهة نظر مجتمع الدر اسة؟ 


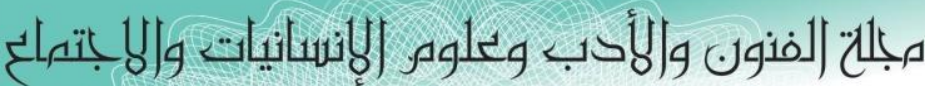

Journal of Arts, Literature, Humanities and Social Sciences

ISSN online: 2414 - 3383

ISSN print: 2616 - 3810

\section{أيلول - سبتمبر 2019}

العدد (43)

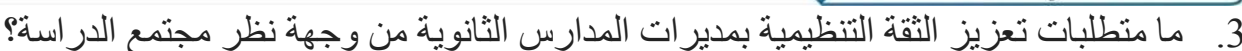

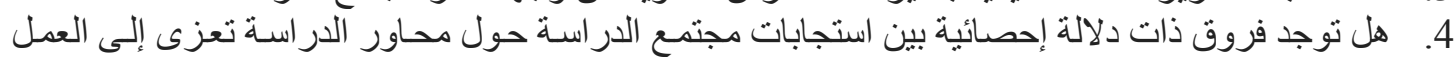

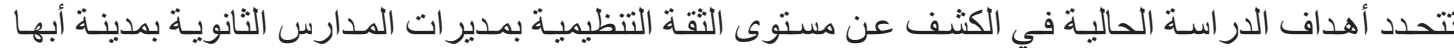
ومحافظة خميس مشيط وذلك من خلال:

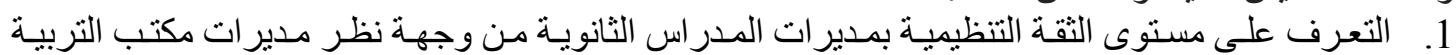

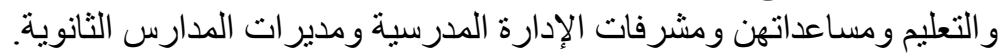
2.

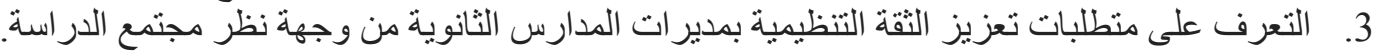
4.

5-1 5-1 5 أهمية الدراسة

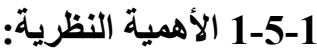

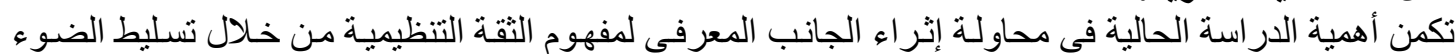

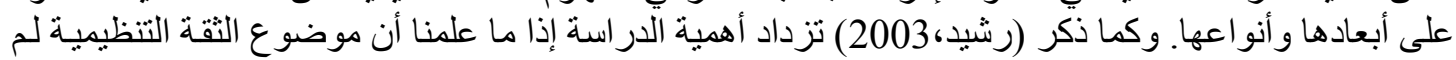

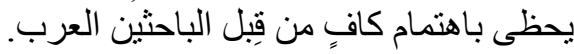

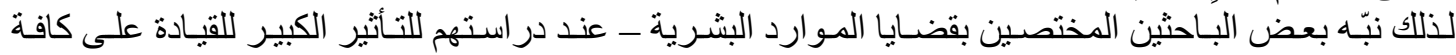

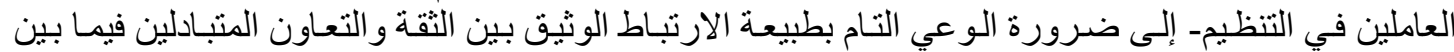

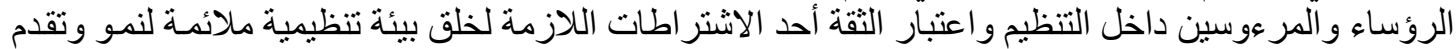

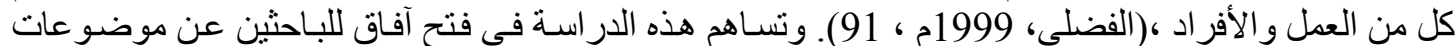
هامة ذات علاقة بالثقة التظظيمية ،كما تعد إضافة للمكتبة العربية و المحلية في مجال الدراسية التات العلية.

2-5-1 الأهمية التطبيقية:

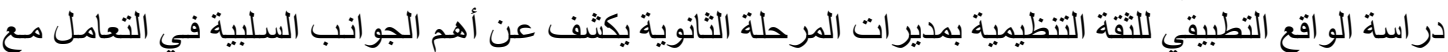

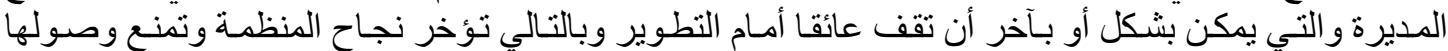

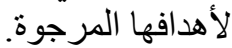
لذا فإنه من المرجو أن تسهم نتائج وتوصيات هذه الدراسة في رسم أهم قو اعد التعامل السليم مع مديرة المدرسة

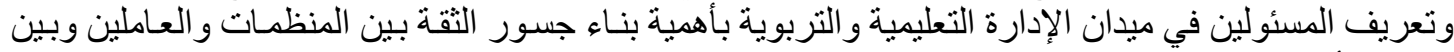

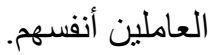

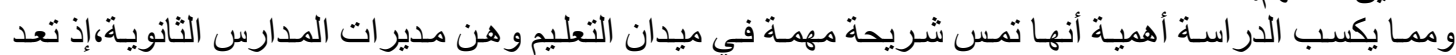

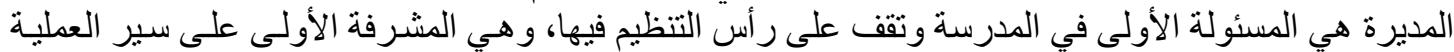

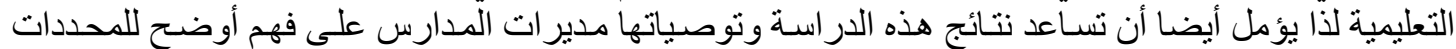

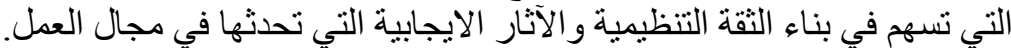

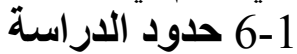
1-6-1 الحدود الموضوعية:تتناول هذه الدر اسة مستوى الثقة التنظيمية بمدير ات المدارس الثانوية بمدينة أبها ومحافظة خميس مشيط.

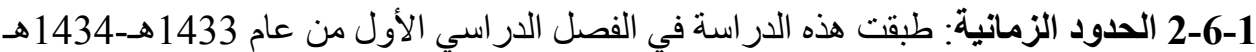

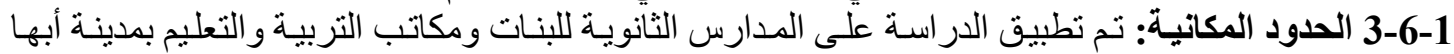
ومحافظة خميس مشيط جنوب المملكة العربية السعودية.

7-1

1-7-1 الثقة التنظيمية: 1-1

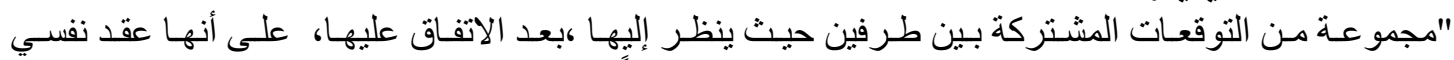
psychological contract غير مكتوب بينهما مع الالتز ام به سلوكاً و علاقة، وينتج عن هذا الاتفاق للعقد النفسي ثقة 
مبلحت (لفنون والأدب وعلوه الإنسانيات والبانتهاع

Journal of Arts, Literature, Humanities and Social Sciences

ISSN online: 2414 - 3383

ISSN print: 2616 - 3810

\section{العدد (43) ايلول - سبتمبر 2019}

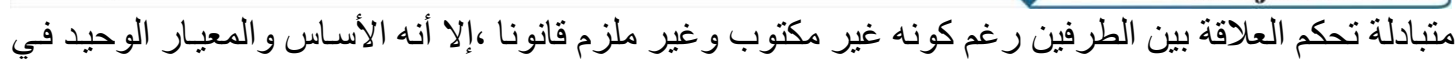

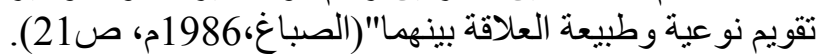

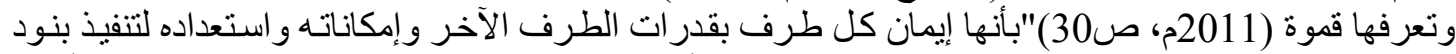

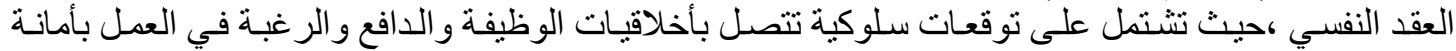
و إخلاص للقيام بالعمل حسب المتطلبات الفنية و الحكم على الأمور بمنطق وموضو عية"

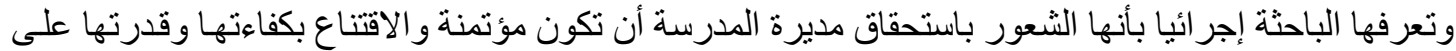

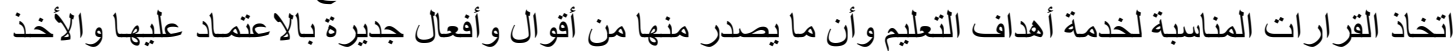

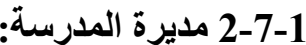
الرئيسة التنفيذية المسئولة عن كافة أنشطة المدرسة في كافة المجالات التربوية، و التعليمية، والأنشطة المدرسية،

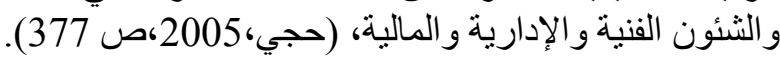

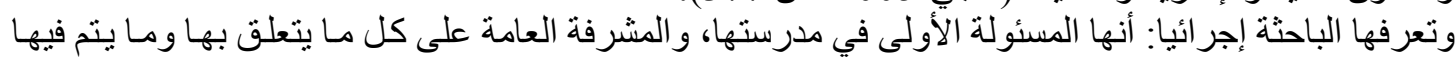

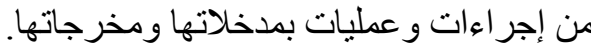

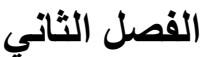 \\ الإطار النظري والدراستات السابقة}

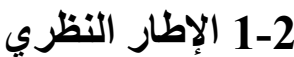

1-1-2 الإطقة التظظيمية (Organizational Trust) لقد أصبح موضوع التقة التنظيمية (Organizational Trust) في السنوات التئة الأخيرة مثار اهتمام الدراسات الإداريـة،

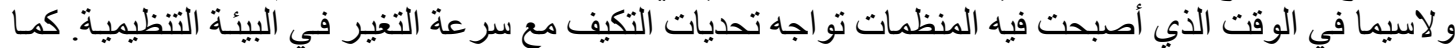

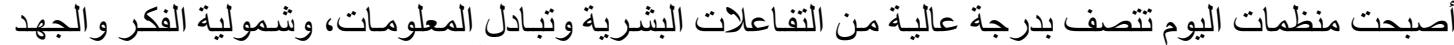

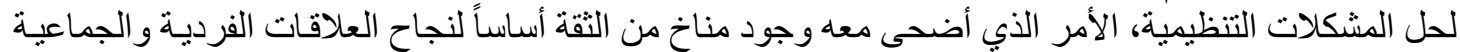

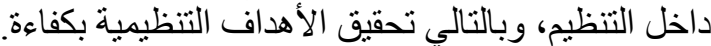
وقد تنبه عدد من الباحثين و المتخصصين إلى أهمية الثقة التنظيمية، وأخذو ا يهتمون بدر اسـة العو امل و المؤثرات

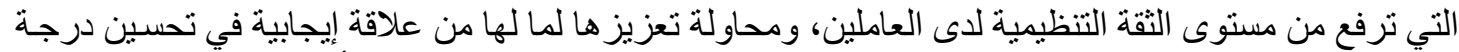

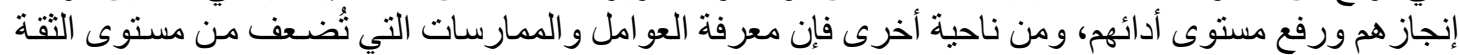

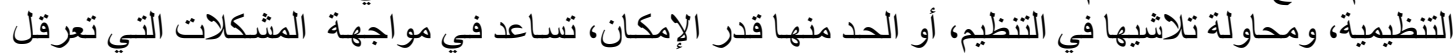

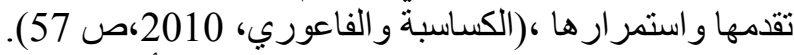

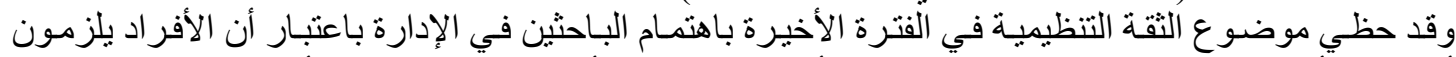

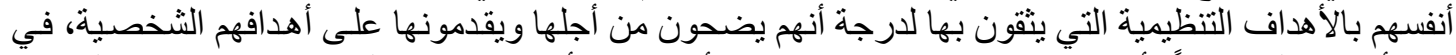

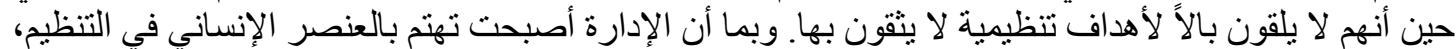

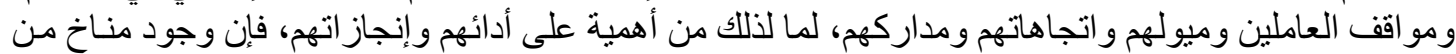

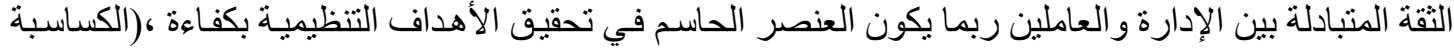

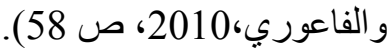

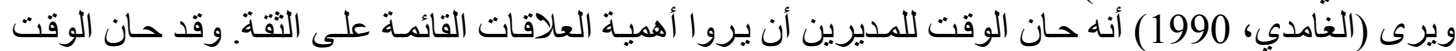

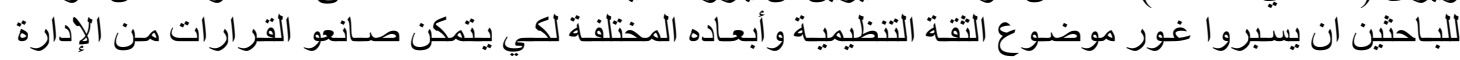
بفعالية وكفاءة عالية. وسيتم تتاول عدد من الأمور المهمة التي تنعلق بالثقة التنظيمية على النحو التالي:

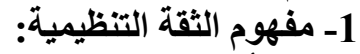

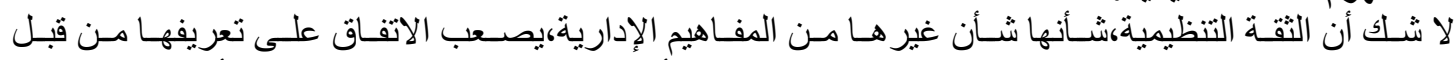
الباحثين،في الوقت الذي يجمع الباحثون في هذا المجال على أهية الثقة المتبادلة في التنظيم، إلا أن هناك اختلاف 


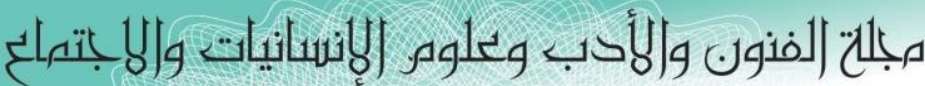

Journal of Arts, Literature, Humanities and Social Sciences

ISSN online: 2414 - 3383

ISSN print: 2616 - 3810

\section{العدد (43) ايلول - سبتهبر 2019}

فيما بينهم في نظرتهم إلبها وطريقتهم في تناول الموضو ع،فكل باحث يحاول أن ينظر إلى المفهوم من زاويته أو

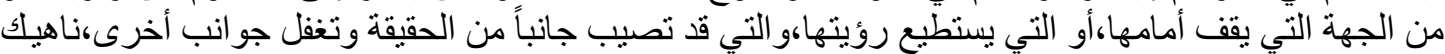
أن الباحث قد يضفي فكره وأيديولوجيته على هذا المفهوم أو ذاك بالر غم من ادعاء البـاحثين الحيـاد و الموضو عية

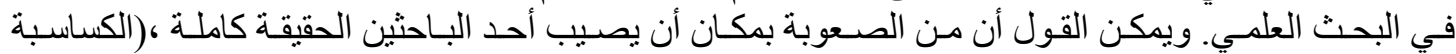

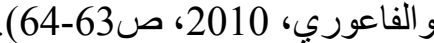
فيشبه روجرز (Rogers) التقة بالمتكلم الذي بمنح المستمع أمانـاً نفسياً،في الوقت الذي يعتبر جيب (Gibb) الثقة

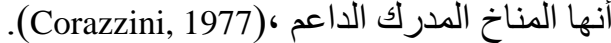

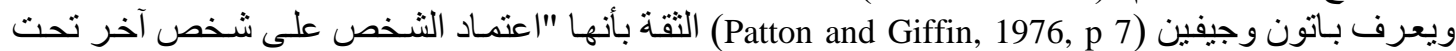

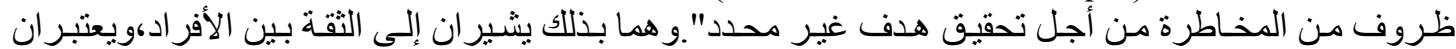

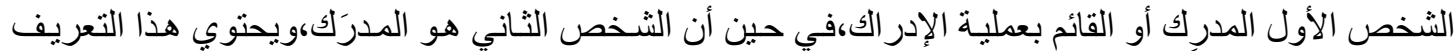

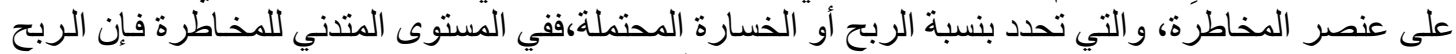

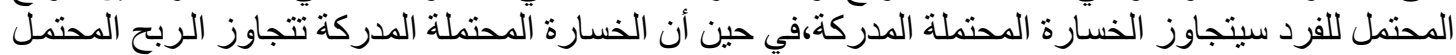

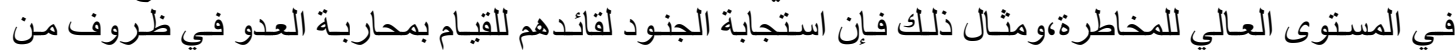

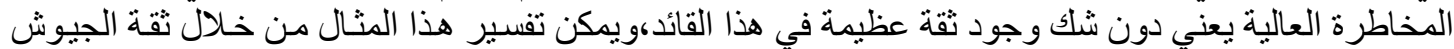

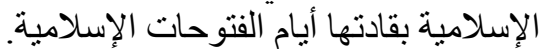

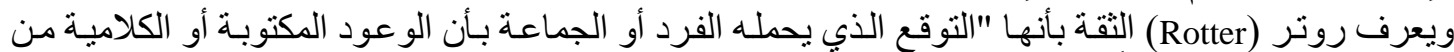

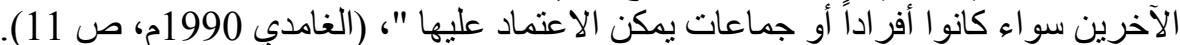

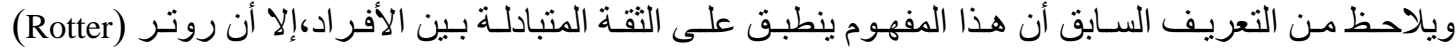
استخدمه في مجال العمل ايضا وقد اعتبر الو عد أو الاتفاق المسبق هو جو هو هر عملية الثقة.

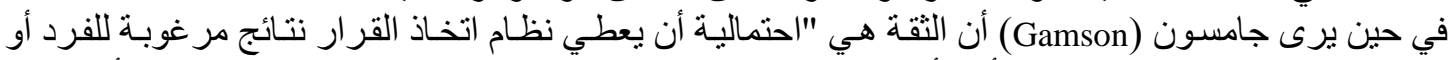

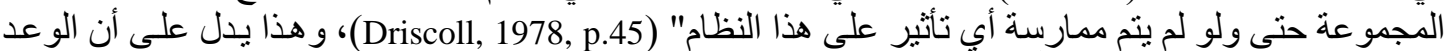

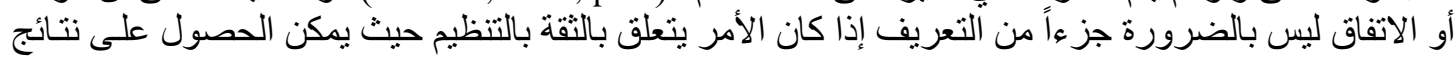

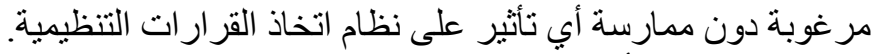

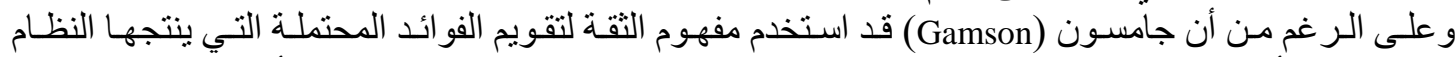
السياسي، إلا أن دريسكول (Driscoll) قد اعتمد على هذا المفهوم ذاته في مجال المنظمات و أطلق عليه اسم التقة التهة

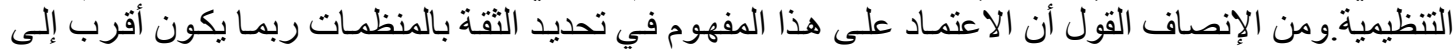

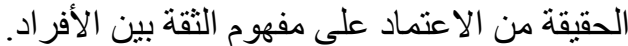

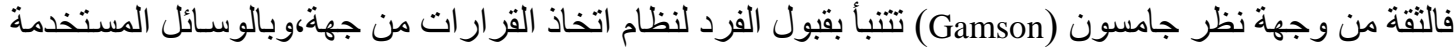
للتأثير على متخذي القرار ات من جهة أخرى.ويتوقع جامسون (Gamson) أن الجماعـات ذات الثقات التهة العالية تقبـل

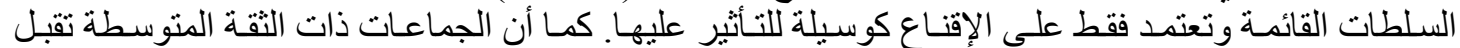

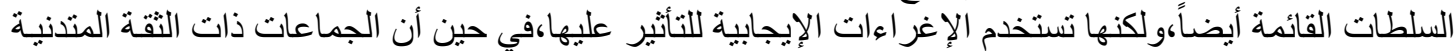

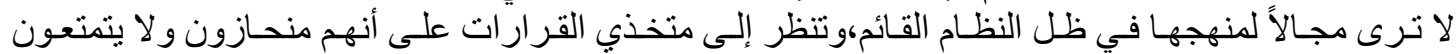

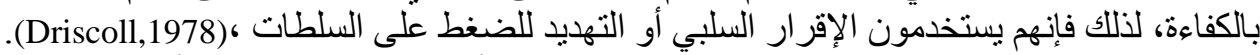
وقد عرف هوي وكوبرسميث (Hoy \& Kopersmith) الثقة بأنها "شعور الفرد بالطمأنينة وحسن الظن، والثن والتفاؤل بما يجري من أُحداث من حوكي له بشكل عام". أي أن الثقة عند الفرد هي توقعـه بشكل عـام بـأن الكلمـات و الأعمـال

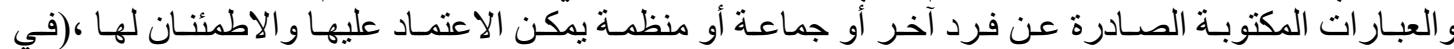

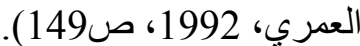

ويعرف منك (Mink) التقة بأنها "توقعات الفرد و ائتمانـه بـأن سلوك الفرد الآخر سبكون سلوكاً منسجماً ومؤيداً

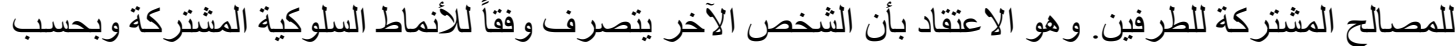

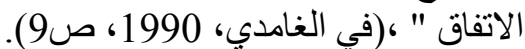

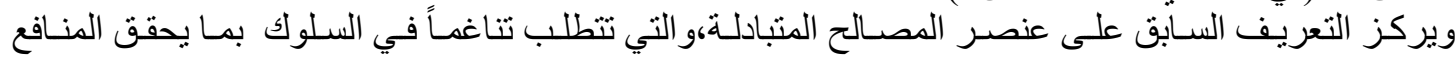
المشتركة مع الإشارة إلى عنصر الاتفاق المسبق،و هذا يتشابه إلى حد كبير مع تعريف روتر (Rotter)،في مجال 


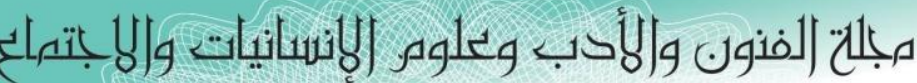

Journal of Arts, Literature, Humanities and Social Sciences

ISSN online: 2414 - 3383

ISSN print: 2616 - 3810

\section{العدد (43) أيلول - سبتمبر 2019}

ضرورة وجود و عد كأساس للتوقعات، في حين يختلف معه في أن روتر (Rotter) لـ يفترض ضـرورة وجود التبادلية في المصالح.

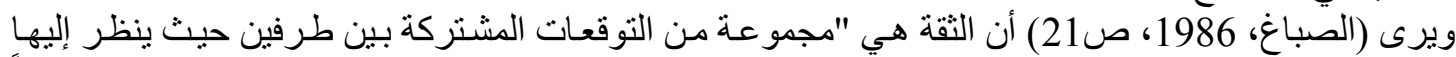

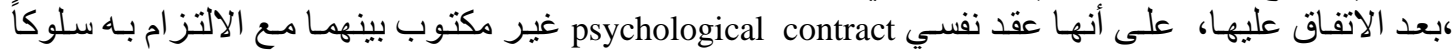

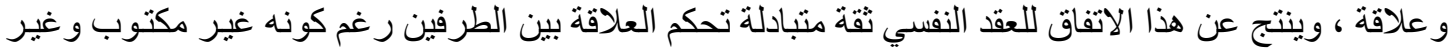
ملزم قانونا ، إلا أنه الأساس و المعيار الوحيد في تقويم نو عية وطبية وطيعة العلاقة بينهما".

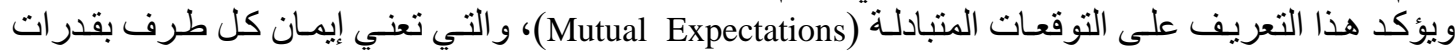

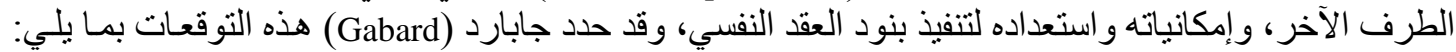
(في الصباغ، 1986) • توقعات سلوكية: وتشمل أخلاقيات الوظيفة، و الدافع والرغبة للعمل بأمانـة و إخلاص، و الاتسـاق في السـلوك

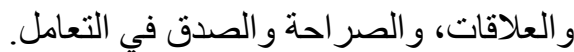

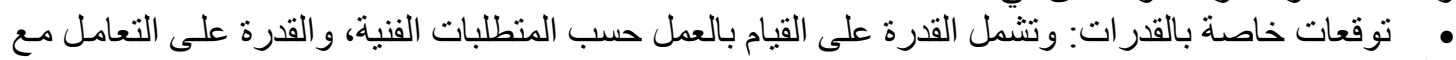
الآخرين بفعالية.

• توقعات حكمية: وتشمل الحكم على الأمور و على الأشخاص الآخرين بمنطق وبموضو عية.

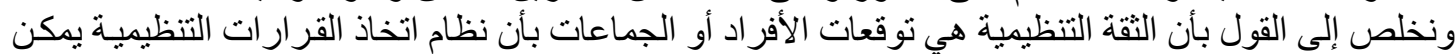

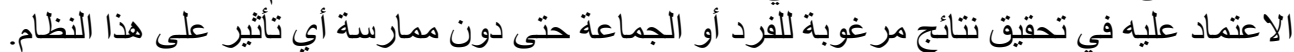

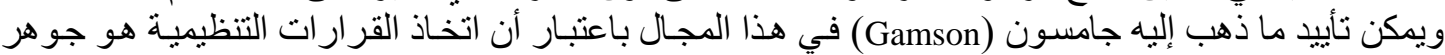

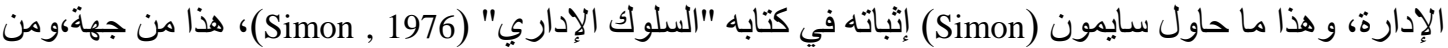

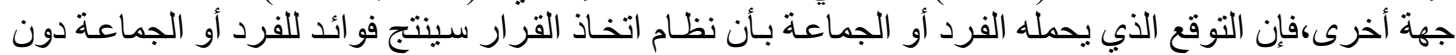

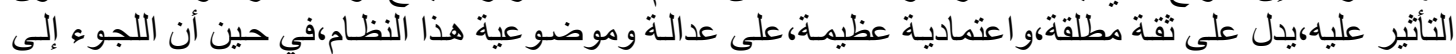

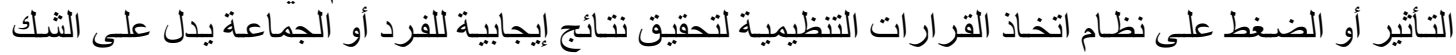
و الريبة بعدالة وموضو الفيز عية هذا النظام.

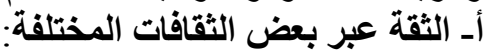

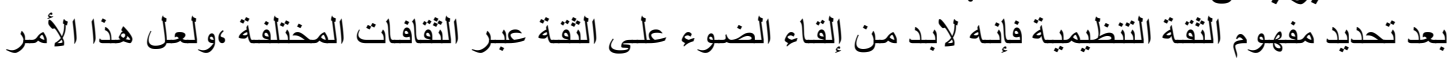

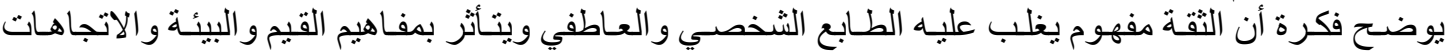

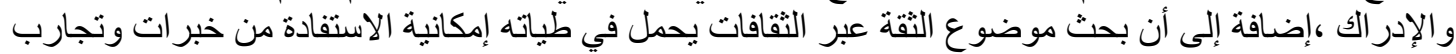

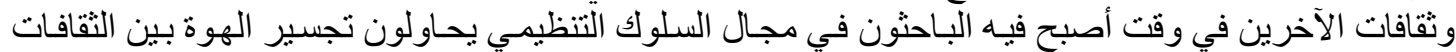

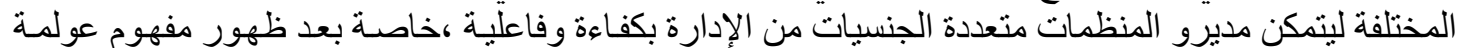

السلوك التنظيمي بعد أن أصبح العالم قرية صنية صغيرة.

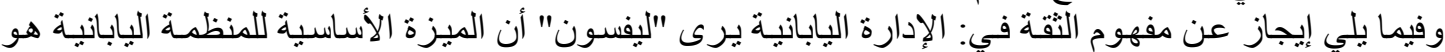

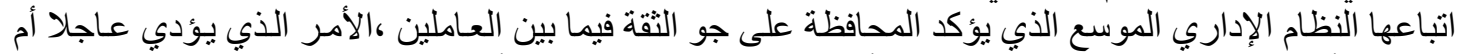

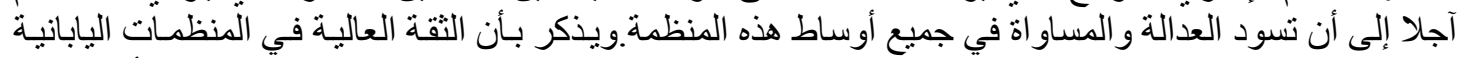

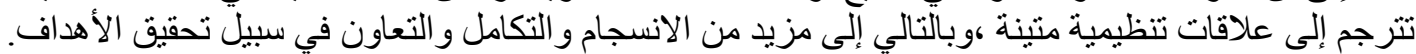
ب ـ الثقة في الإدارة الإسلامية:

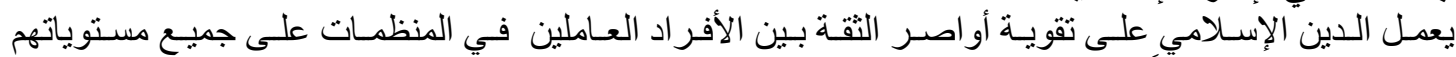

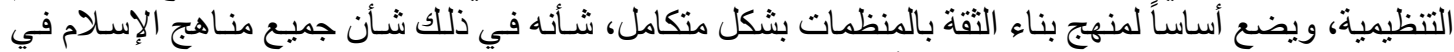
تتظيم حياة البشر، ويقوم هذا المنهج على الأسس التالية: (بدر، 1987)

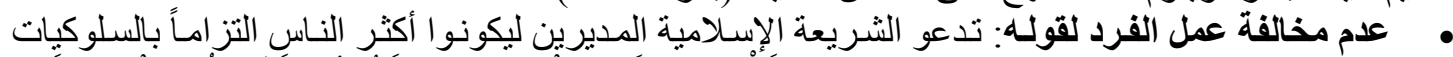

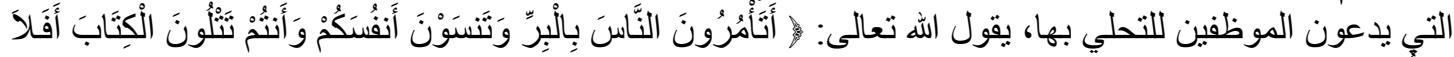

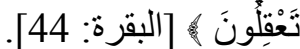

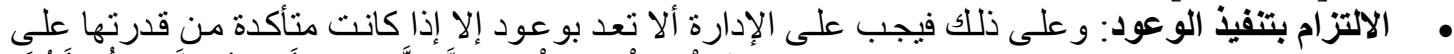

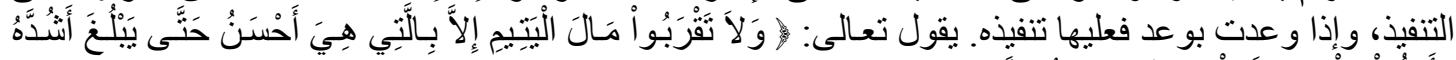

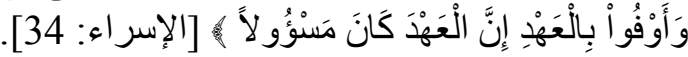




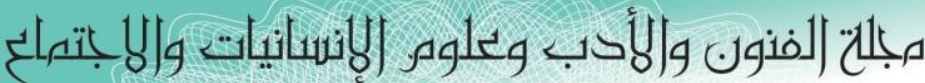

Journal of Arts, Literature, Humanities and Social Sciences

ISSN online: 2414 - 3383

ISSN print: 2616 - 3810

\section{العدد (43) ايلول - سبتمبر 2019}

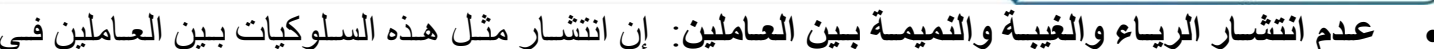

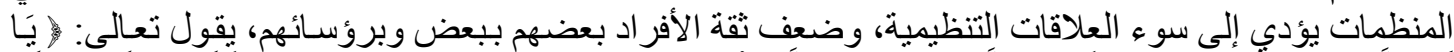

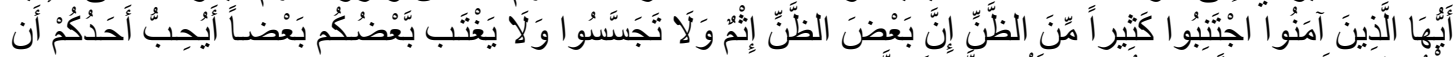

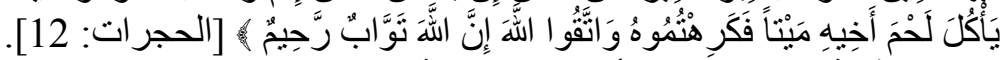

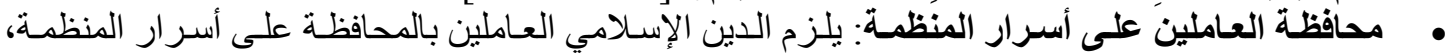

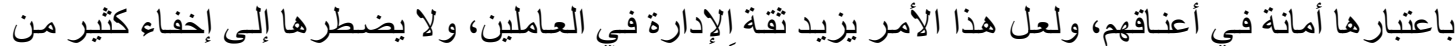

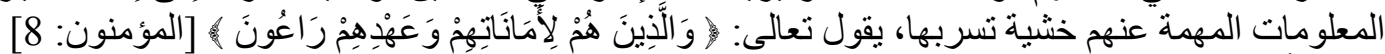

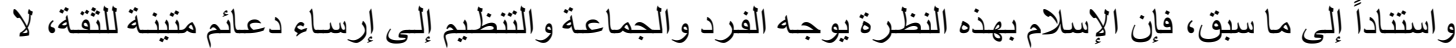

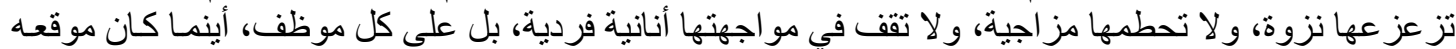

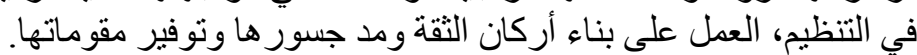

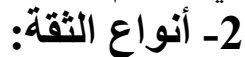

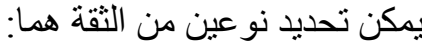
أ ـ الثقة التعاقدية (Contractual Trust):

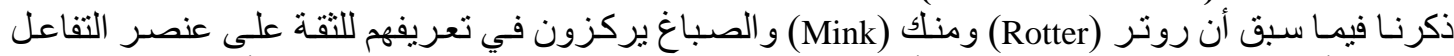

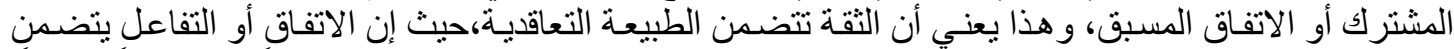

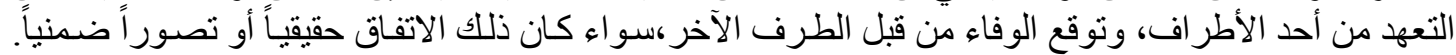

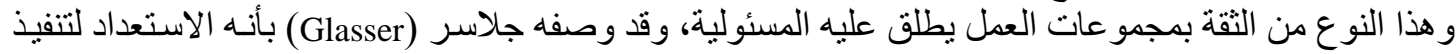

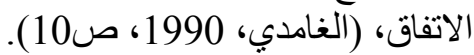

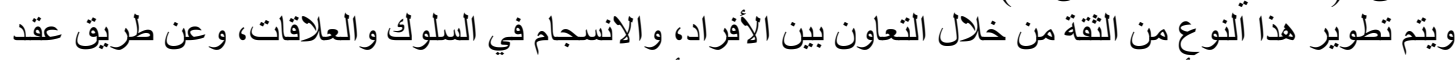

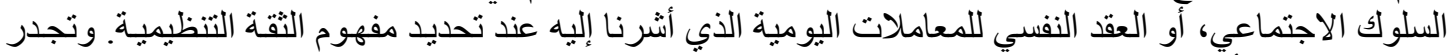

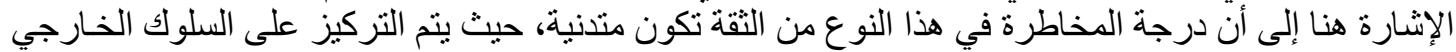

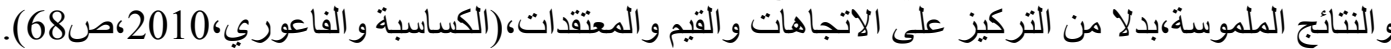

ب ـ الثقة المكشوفة (Disclosure Trust)

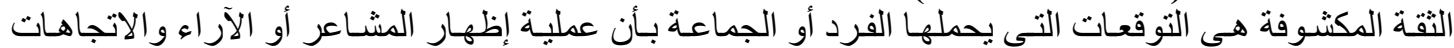

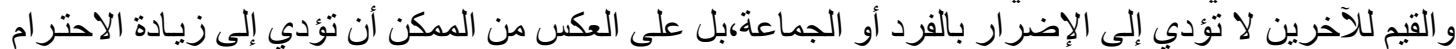

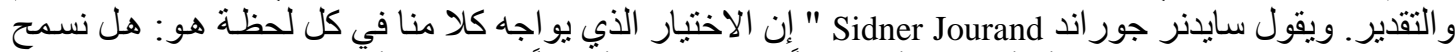

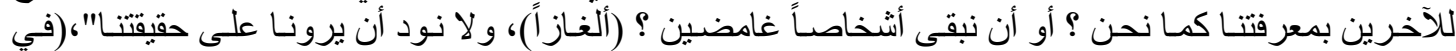

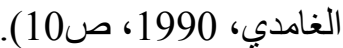

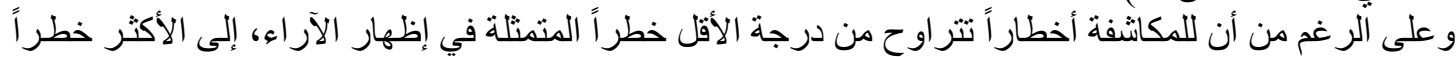

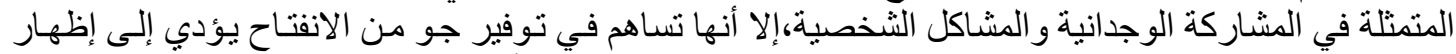

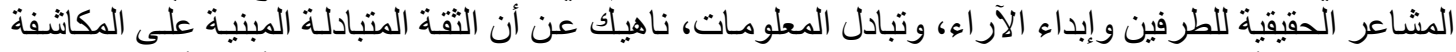

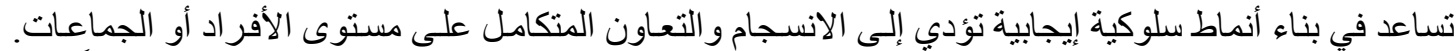

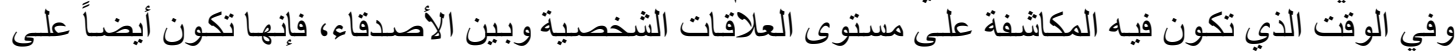

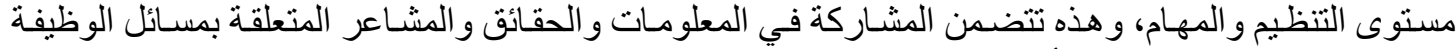

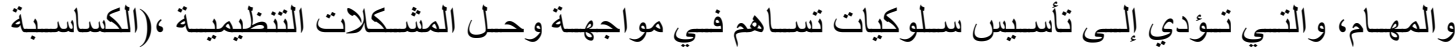

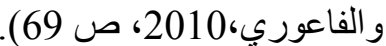

وتؤيد الباحثة أن الثقة المكثوفة تساهم بطريقة أو بأخرى في مو اجهة المشكلات التنظيمية التي قد تعتري المنظمة

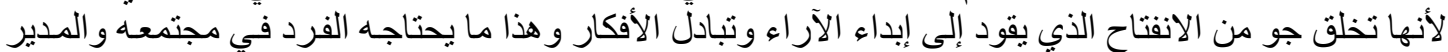

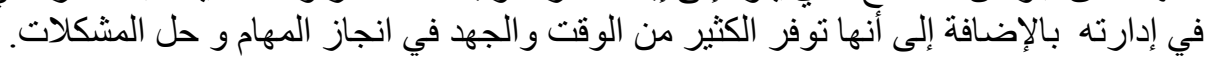

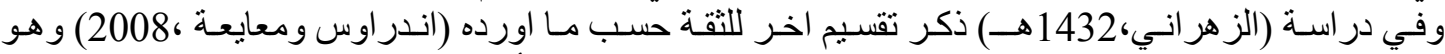

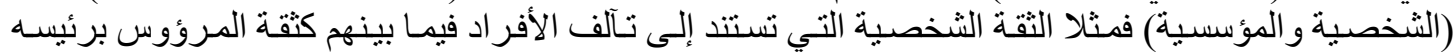




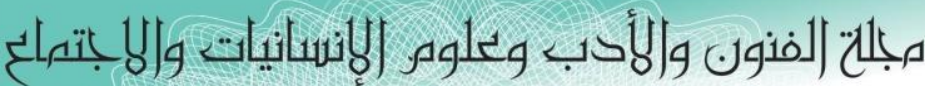

Journal of Arts, Literature, Humanities and Social Sciences

ISSN online: 2414 - 3383

ISSN print: 2616 - 3810

\section{أيلول - سبتمبر 2019}

العدد (43)

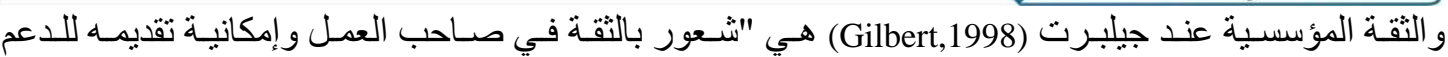

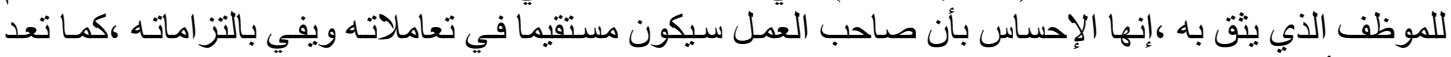

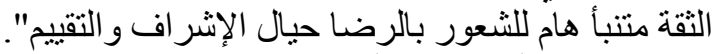
ـ محددات الثقة المؤسسية:

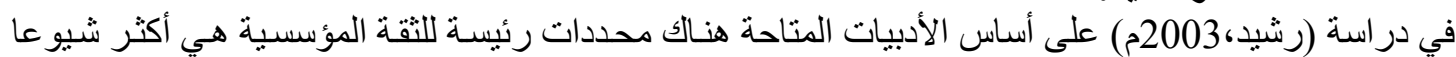
و استخداما، وتتضمن هذه المحددات العدالة التنظيمية و الدعم التنظيمي:

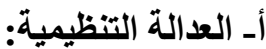

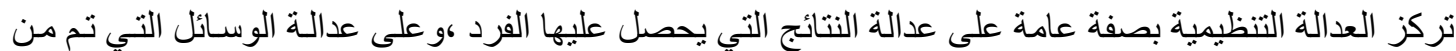

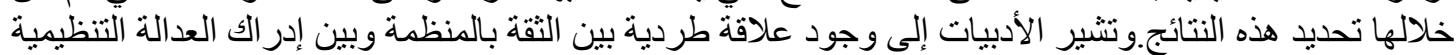
بنو عبها التوزيعية و الإجر ائية.

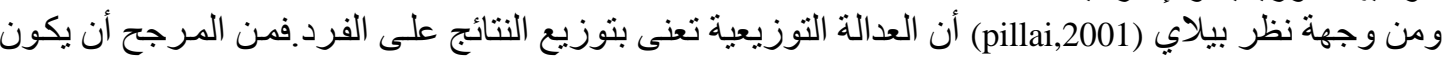

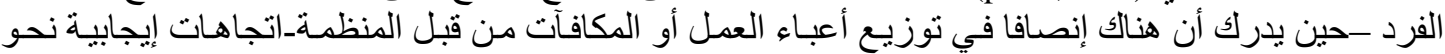

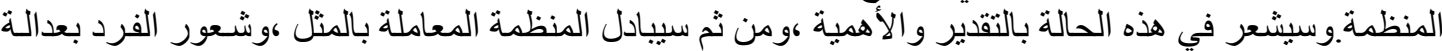
توزيع المخرجات يؤثر إيجابيا في ثقته بالمنظمة.

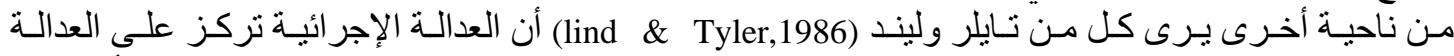

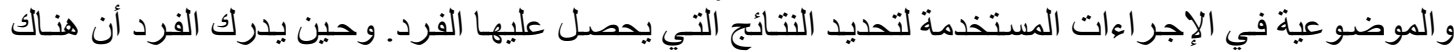
إنصافا في الإجر اءات المستخدمة ، سيشعر باتجاهـات إيجابية نحو المنظمـة ،وتتضمن هذه الاتجاهات الإليجابية الإنية

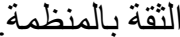

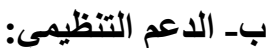

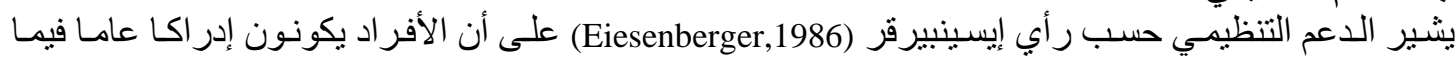

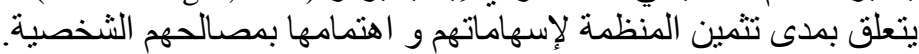
3 - قواعد الثقة التنظيمية:

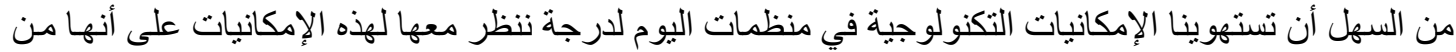

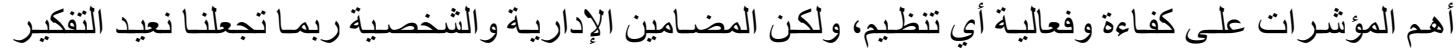

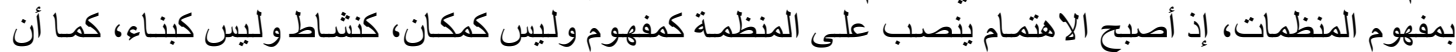

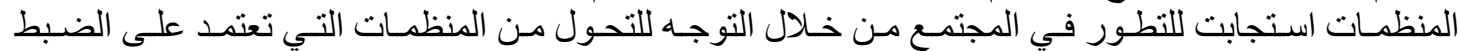

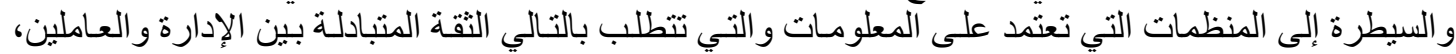

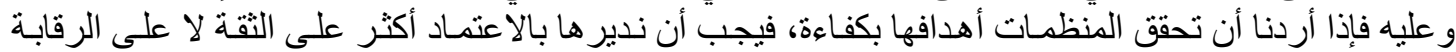

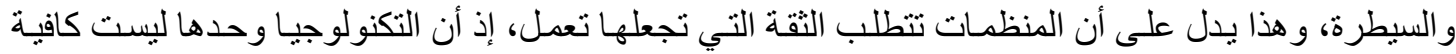

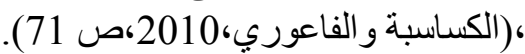

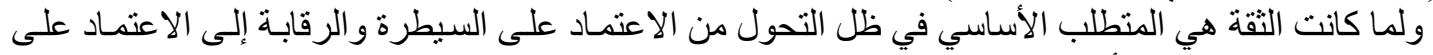

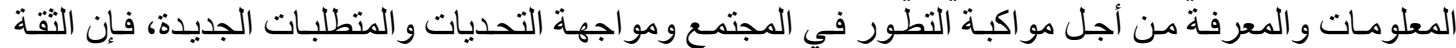

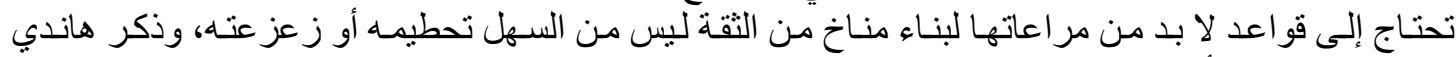
(Handy, 1995)، أهم هذه القو اعد كما يلي:

أـ عدم الإفراط في الثقة بالآخرين:

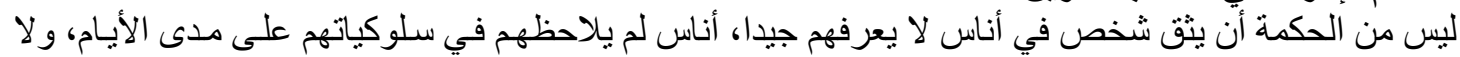

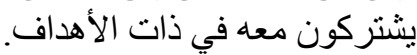

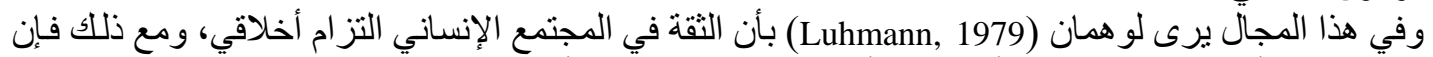

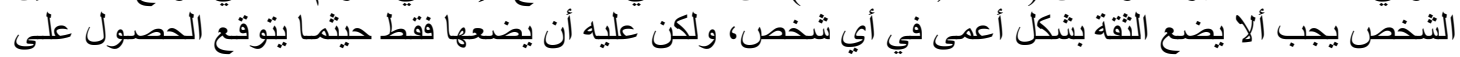


مبلحت (لفنون والأدب وعلوه الإنسانيات والبانتهاع Journal of Arts, Literature, Humanities and Social Sciences

ISSN online: 2414 - 3383

ISSN print: 2616 - 3810

أيلول - سبتمبر 2019

العدد (43)

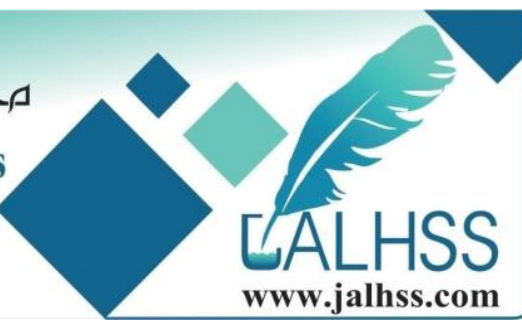

ب بمحدودية الثقة:

إن الثقة دون حدود تعني في الممارسـة ثقة غير واقعيـة، والثقة بحدود في المنظمـات تعني الثقـة بقدرة العـاملين

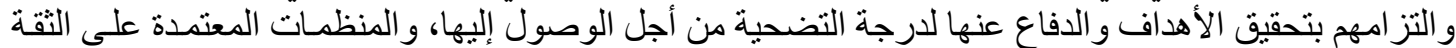

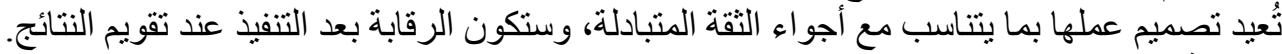
ج-الثقة تتطلب القدرة على التعلم والتكيف:

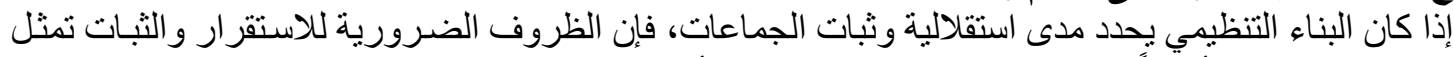

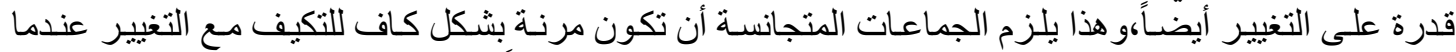

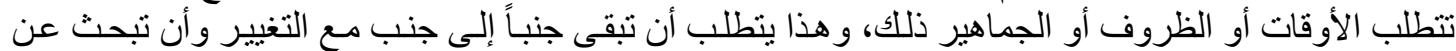

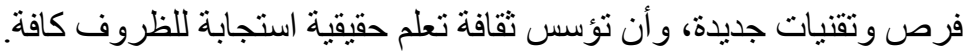

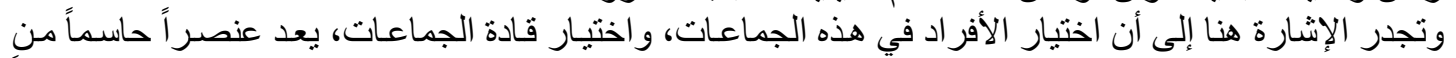

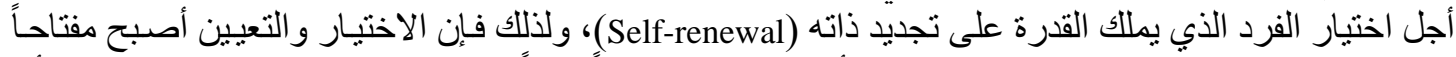

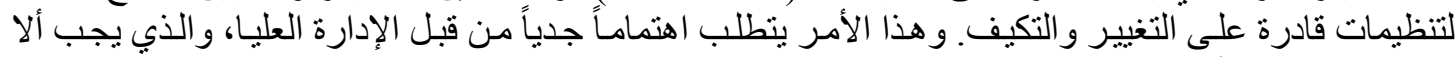
يفوَّض لمستويات أدنى في التنظيم.

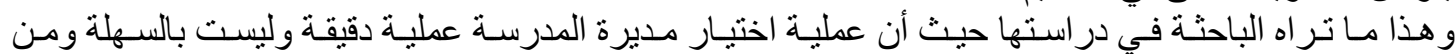

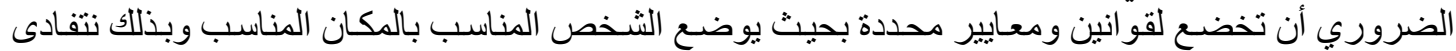
الكثير من الأزمات التي ق تو اجه المنظمة في حالة وجود مديرة مدرسة ينقصها الكثير من المهار ات.

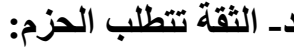
إذا ما أخفقت الإدارة في اختيار موظفين لإيهم القدرة على التكيف وتجديد الذات، وثبت أن الثقة غير موجودة ليس

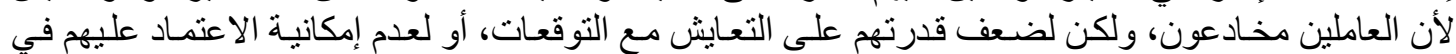

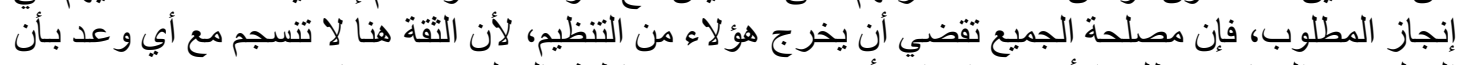

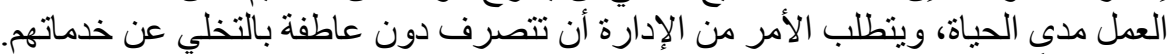

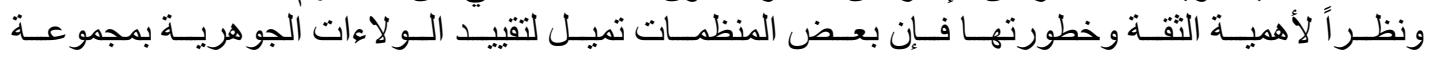

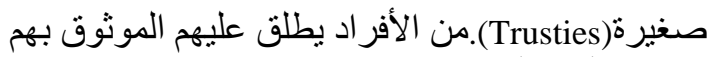

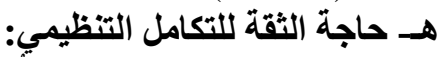

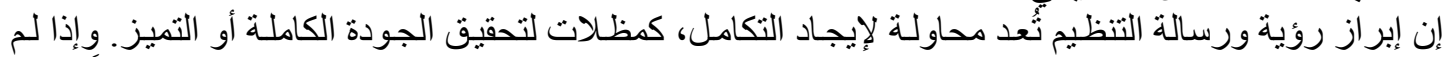
يوجد ذلك التكامل فإن ذللك سيؤدي إلى حدوث خلل أو مشكلة في المنظمة. ويذكر هنا أن التكامل ليس كافياً وحده

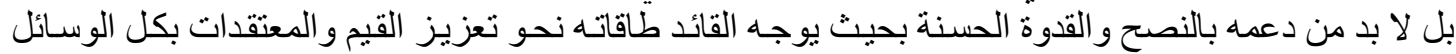
الممكنة.ومن أجل أن يعمل الجميع فيجب أن لأن تلتقي أهداف المنظمات الصغيرة مع أهداف المنظمات الكبيرة. و- حاجة الثقة للاتصال:

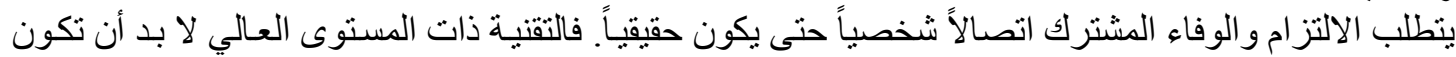

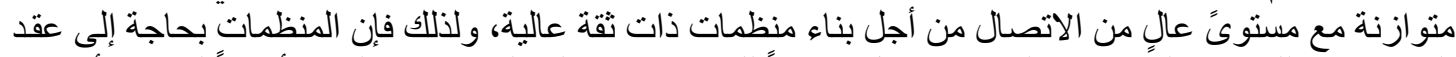

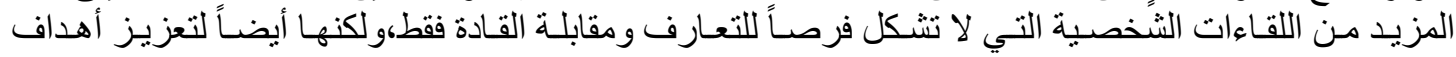

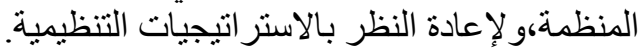
4- مكوناث الثقة التثظيمية: توصل (الغامدي،1990) إلى أربعة مكونات للتقة التنظيمية و التي يطلق عليها أبعاد التقة التنظيمية وهي: أ- السبياسات الإدارية: ويتضنمن هذا العامل العناصر التالية:

$$
\begin{aligned}
& \text { العدالة في الترقية. } \\
& \text { الترقيات و المكافآت للمجدين. } \\
& \text { عدم المبالغة في عرض الحقائق. } \\
& \text { الشعور بوجود فرص للترقي. }
\end{aligned}
$$




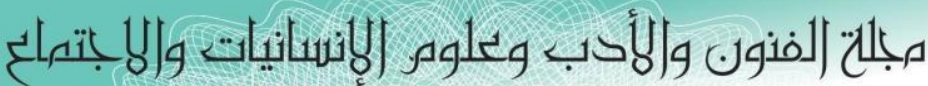

Journal of Arts, Literature, Humanities and Social Sciences

ISSN online: 2414 - 3383

ISSN print: $\mathbf{2 6 1 6 - 3 8 1 0}$

\section{العدد (43) أيلول - سبتهبر 2019}

وجود سياسات إدارية و اضحة.

التعامل الجيد من قبل الإدارة.

المشاركة في صنع القرار.

تو افر الفرص التدريبية.

ب ـ الابتكار وتحقيق الأات: ويتضمن هذا العامل العناصر التالية:

ثقة الإدارة بقدرات الموظفين.

ثناء الرؤساء على جهود الموظفين.

تفويض السلطات.

تشجيع الابتكار و التجديد في العمل.

الثقافة العالية للرؤساء.

ج- القيم السائدة: ويتضمن هذا العامل العناصر التالية:

شعور الموظف بأن رئيسه شخص متدين.

حرص الرئيس على أداء الثعائر الدينية.

ثقة الموظف بكفاءة رئيسه.

تطبيق النظام على الجميع.

دـ توافر المعلومات: ويتضمن لفن هذا العامل العناصر التالية:

$$
\text { تو افر المعلومات. }
$$

مصداقية المعلومات.

احتر ام الإدارة لموظفيها.

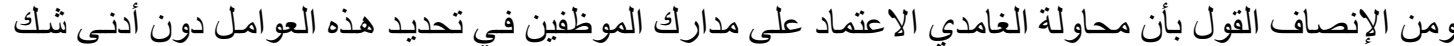

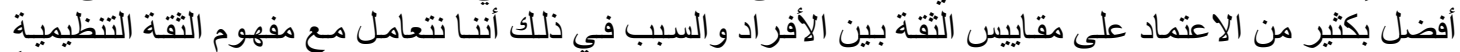

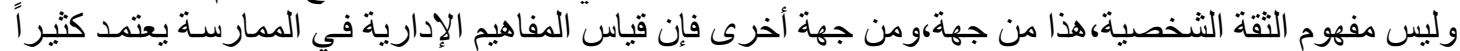

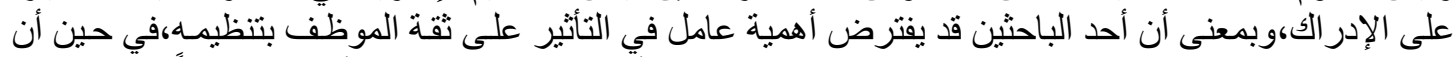

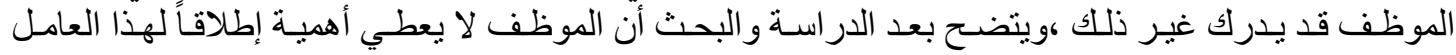
(الكساسبة و الفاعوري، فوري، 2010م).

5- 5 أبعاد الثقة التظظيمية:

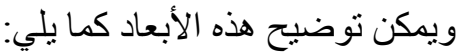
أ ـ السبياسات الإدارية:

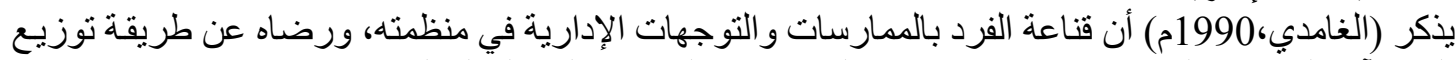

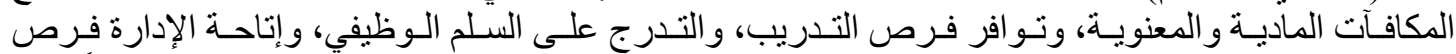

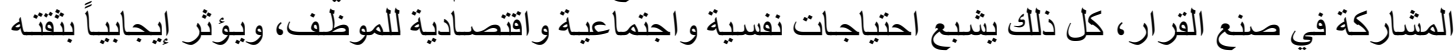

بمنظمته وبسياساتها الإدارية.

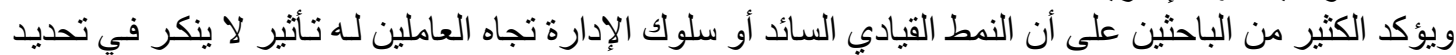

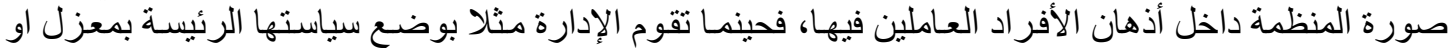

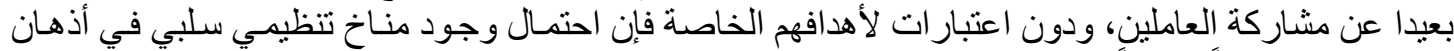

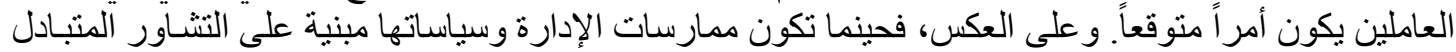

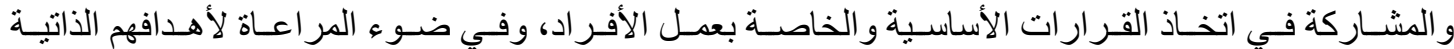




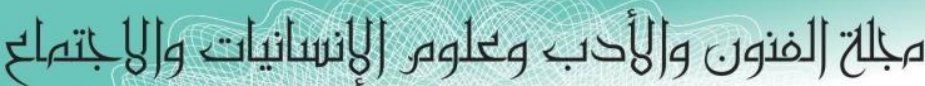

Journal of Arts, Literature, Humanities and Social Sciences

ISSN online: 2414 - 3383

ISSN print: 2616 - 3810

\section{العدد (43) ايلول - سبتمبر 2019}

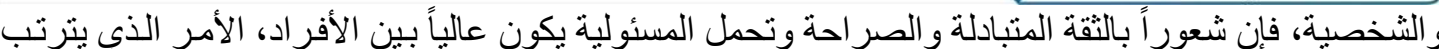

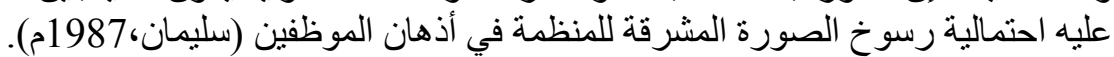

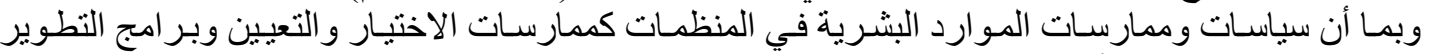

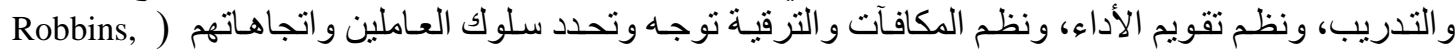

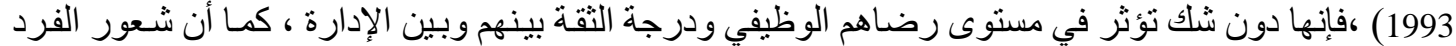

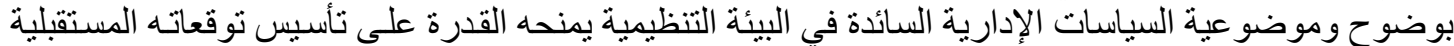

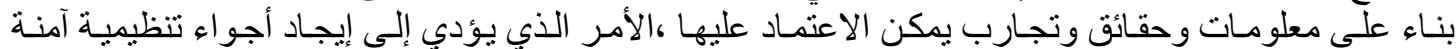

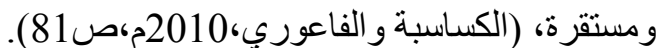

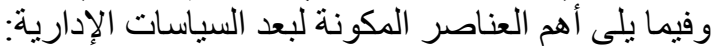

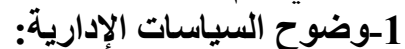

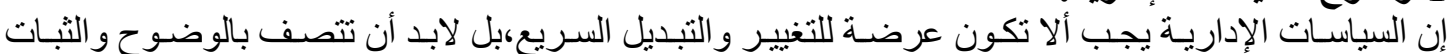

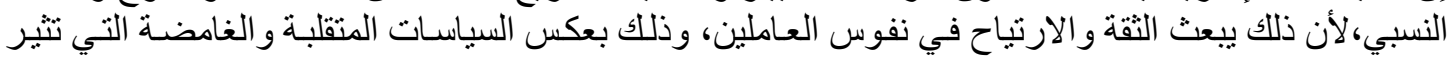

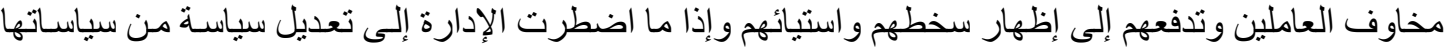

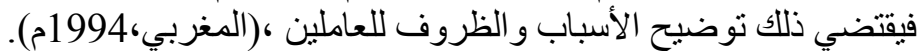

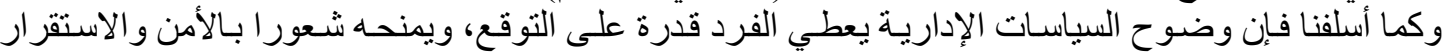

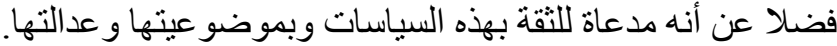

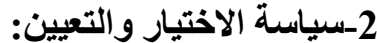

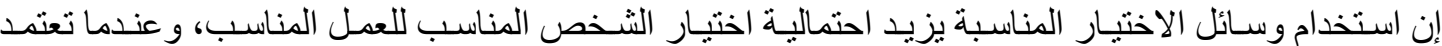

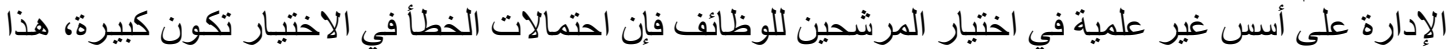

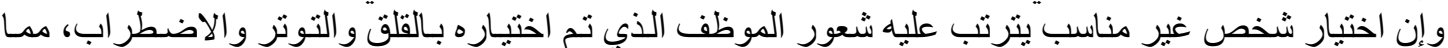

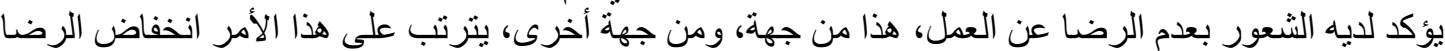

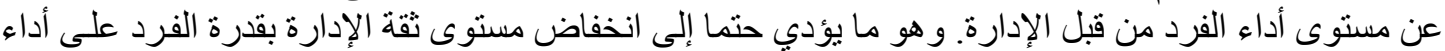

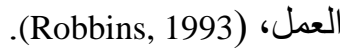
كما أن اختيار الأفر اد للعمل في المنظمات من أهم الوسائل التي تعتد عليها الإدارة في تأسيس فرق عمل يمكن

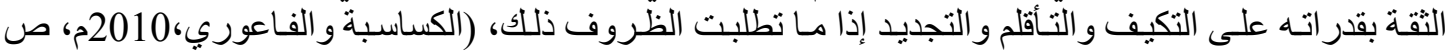

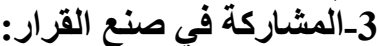

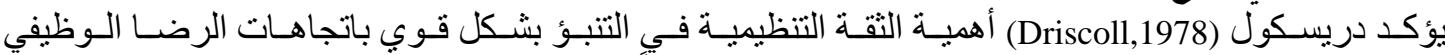

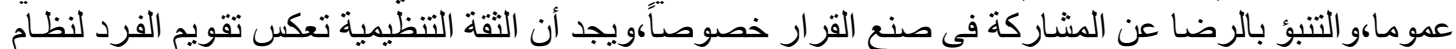

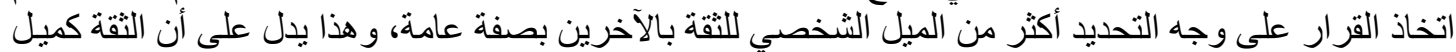

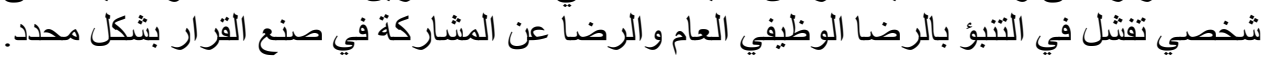

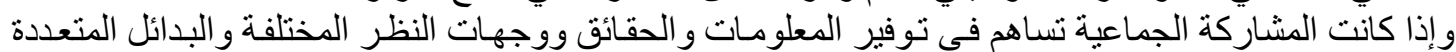

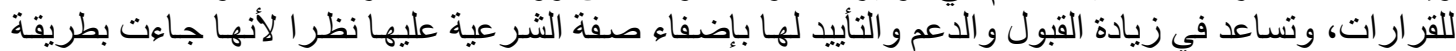

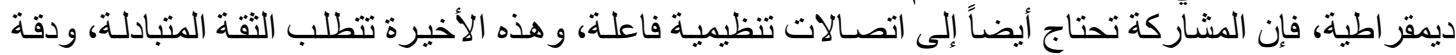

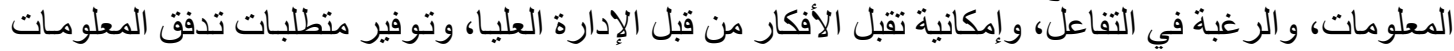
من المستويات الدنيا إلى المستويات العليا ، Robbins, 1993).

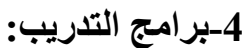

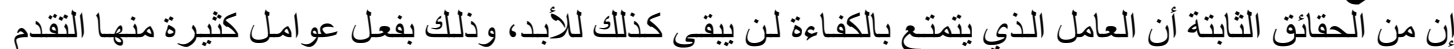

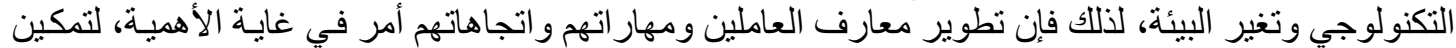

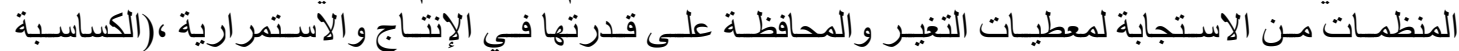

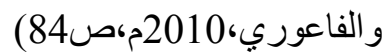




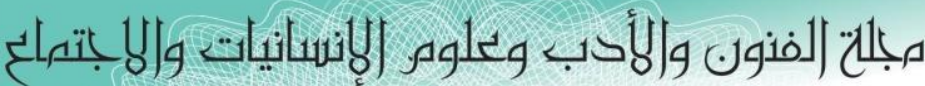

Journal of Arts, Literature, Humanities and Social Sciences

ISSN online: 2414 - 3383

ISSN print: 2616 - 3810

\section{أيلول - سبتمبر 2019}

العدد (43)

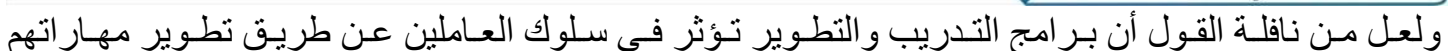

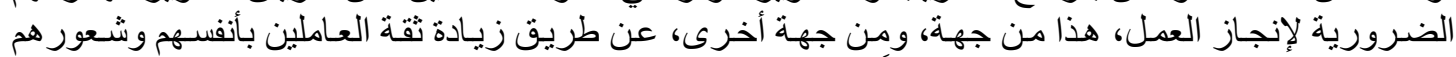

بالقدرة على إنجاز العمل بمهارة عالية، نظر أل لما تلقوه من تدريب (Robbins, 1993).

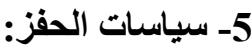

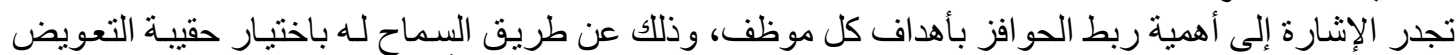

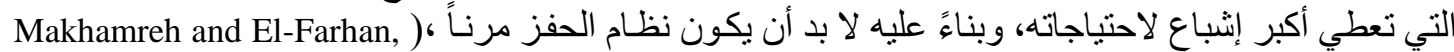

1990

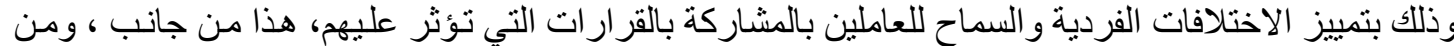

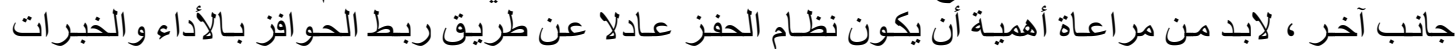

و والقدرات والجهود المبذولة لتحقيق الأهداف المحددة، (Robbins,1993).

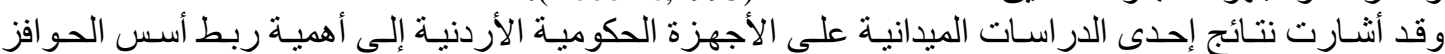

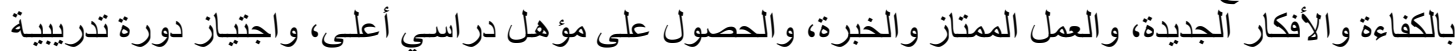

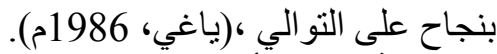
6- 6 عملية تقويم الأداء:

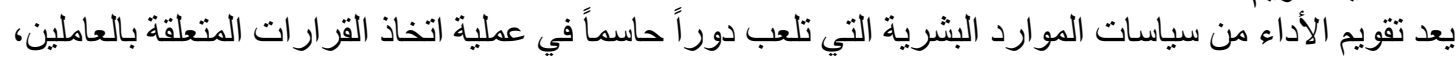

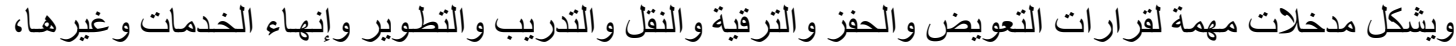

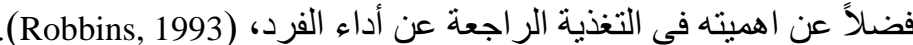

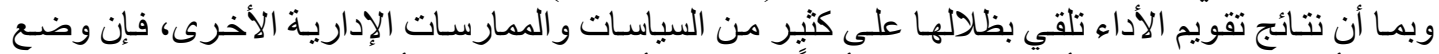

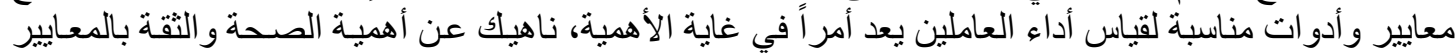

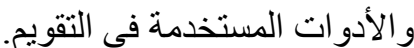

وتقاس الثقة بالمعايير عن طريق قياس الثبات (Consistency)، و الاستقرار (Stability)

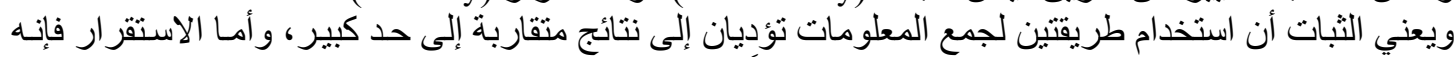

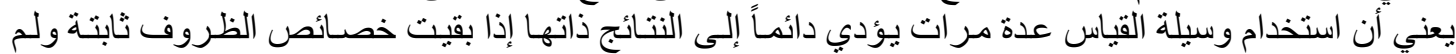

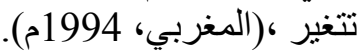

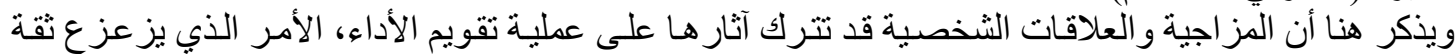

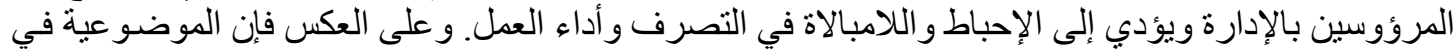

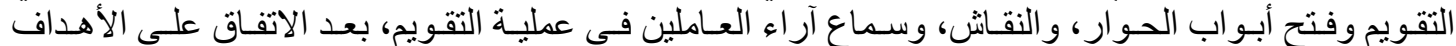

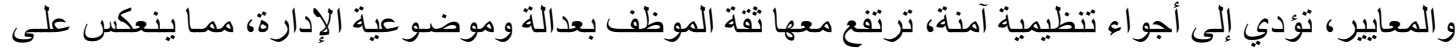

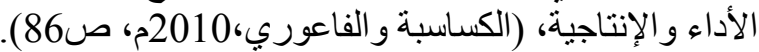

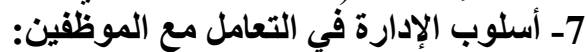

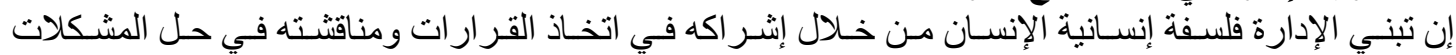

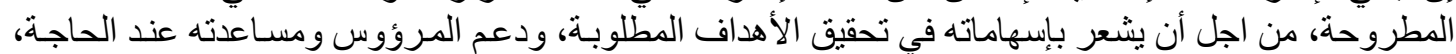

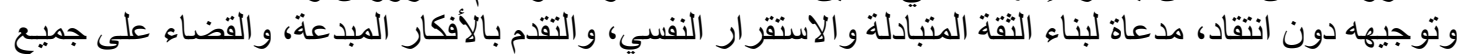

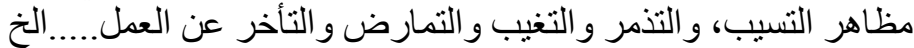

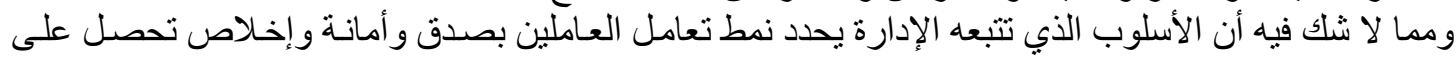

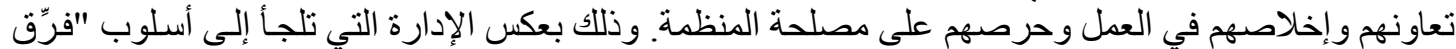

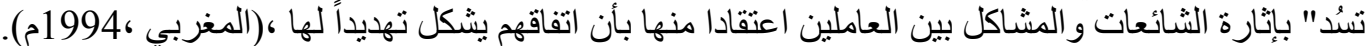

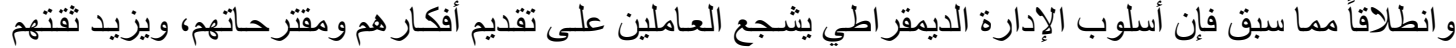

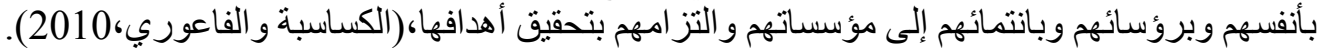
بـ - فرص الابتكار وتحقيق الذات:

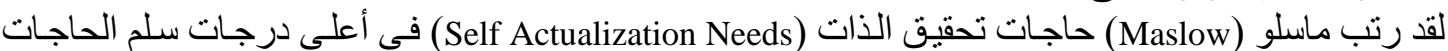
الإنسانية و التي تتضمن ضرورة أن يشعر الفرد بإمكانياته وأن يتلكس إنجاز اته وقدر اته على تتمية وتطوير ذاته. 


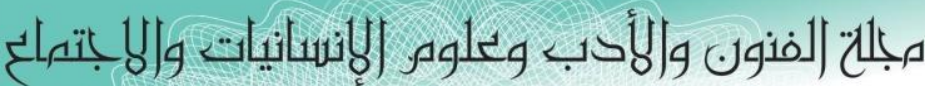

Journal of Arts, Literature, Humanities and Social Sciences

ISSN online: 2414 - 3383

ISSN print: 2616 - 3810

\section{ايلول -سبتمبر 2019}

العدد (43)

وباختصار فإن حاجات تحقيق الذات تعني استغلال المو اهب و الوصول إلى أعلى مركز يمكن أن يصله الفرد

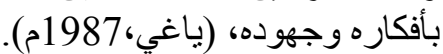

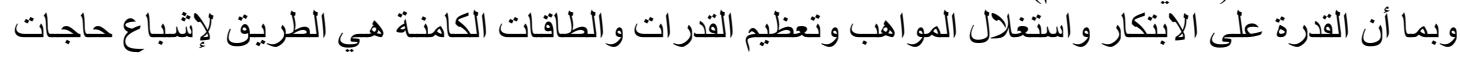

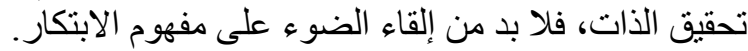

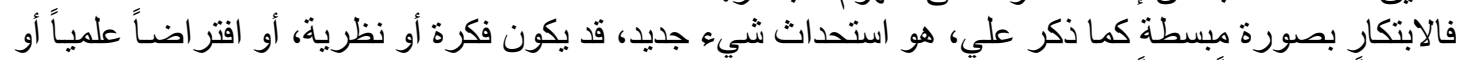

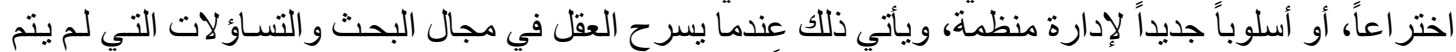

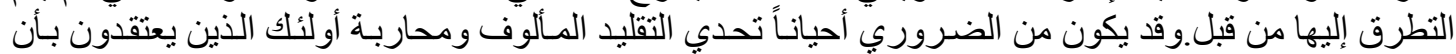

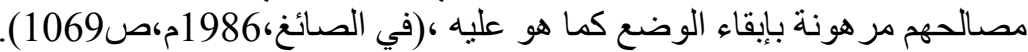

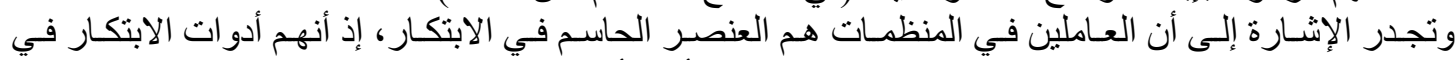

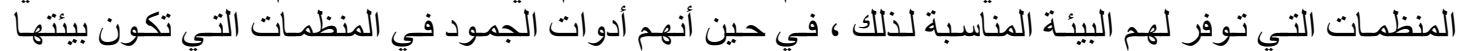

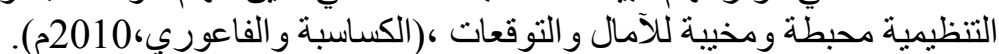

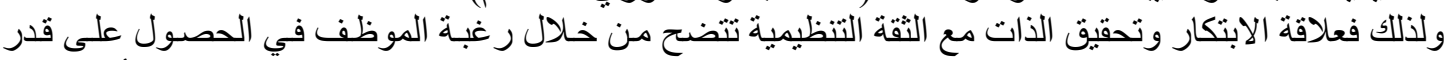

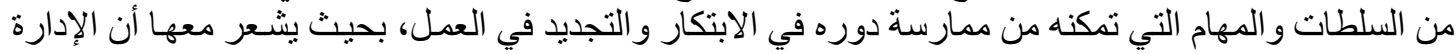

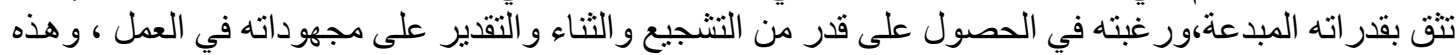

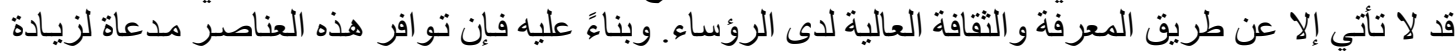

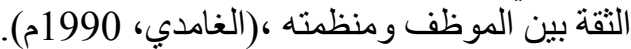

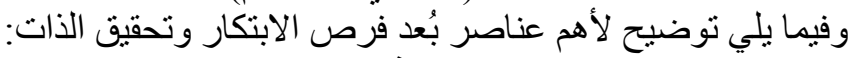

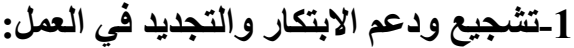

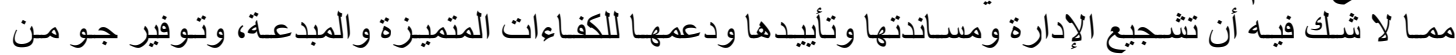

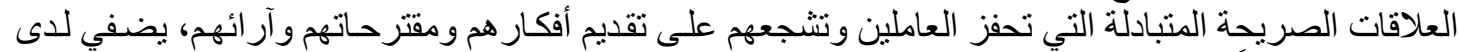

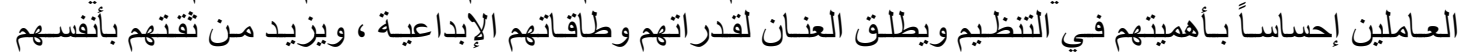

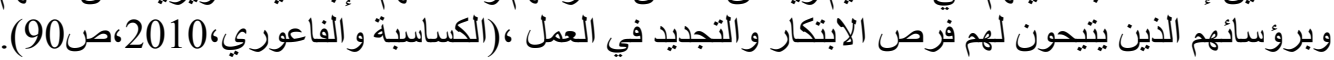
2-تفويض السلطات والصلاحيات:

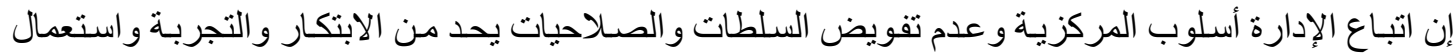

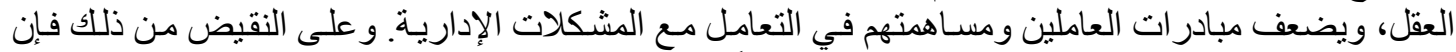

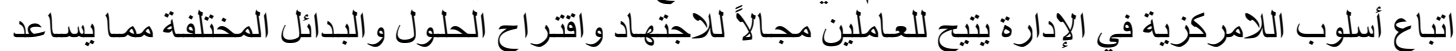

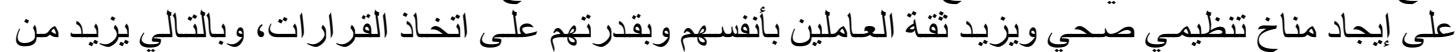

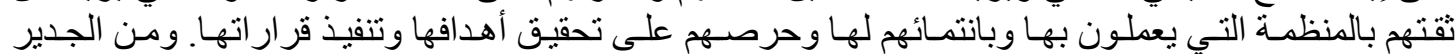

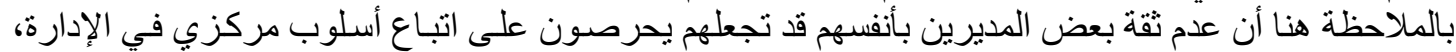

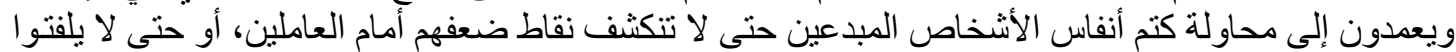

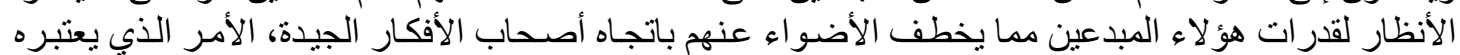

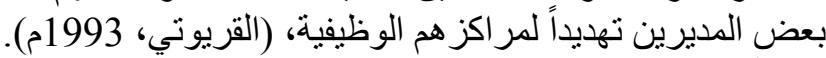
3-ثقة الإدارة بقرات العبرد العاملين:

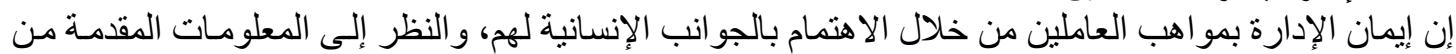

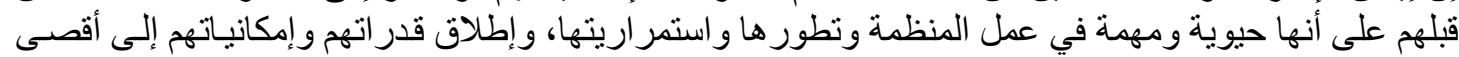

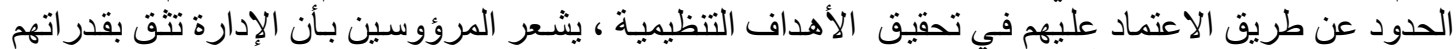

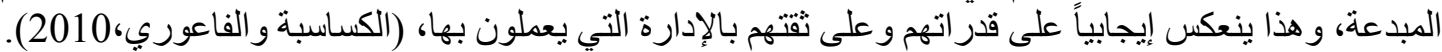

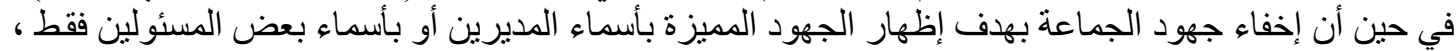

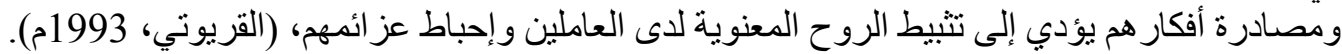
4-تقدير الإدارة لمجهودات هنود العاملين:

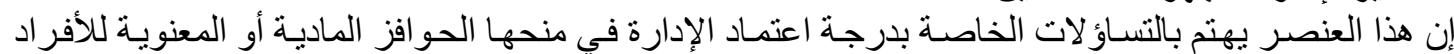

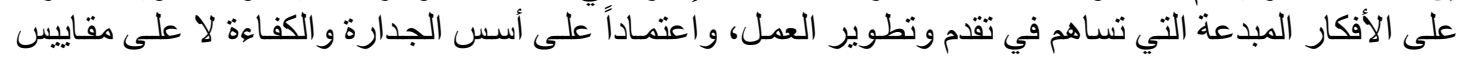
نظم المحسوبية والاعتبار الات الثخصية واهي والعاطفية. 


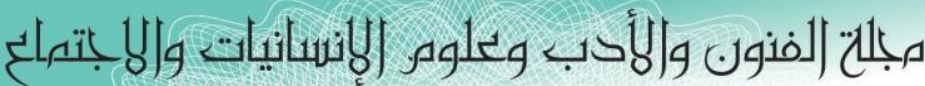

Journal of Arts, Literature, Humanities and Social Sciences

ISSN online: 2414 - 3383

ISSN print: 2616 - 3810

\section{أيلول - سبتمبر 2019}

العدد (43)

و عليه فإن المنظمات التي تسعى إلى التميز وتقديم أفضل الخدمات يجب ألا تـألْ جهداً في إتاحـة المجال لتنميـة

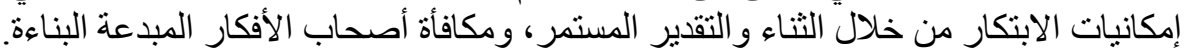

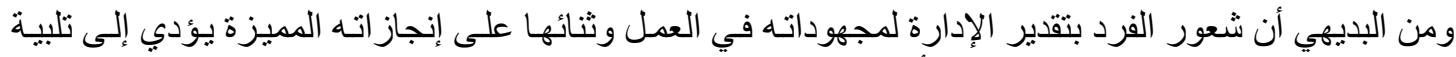

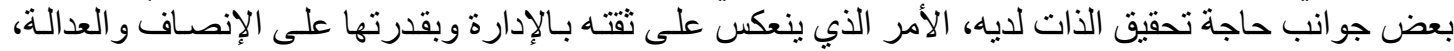

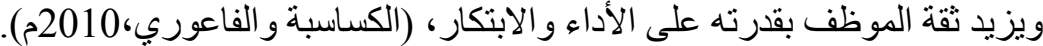

5-الثقافة العالية للرؤساء:

إن توفير متطلبات الابتكار وتحقيق الذات بدءاً من تشجيع الأفكار المبدعة وتقدير مجهودات الموظفين، ومـروراً

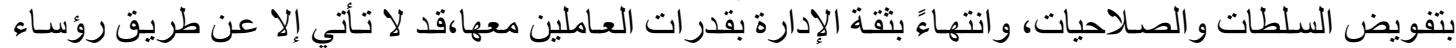

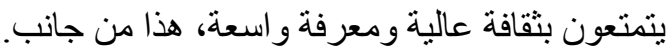
ويشير بعض الباحثين إلى أن أهم مميز ات مدير المستقبل تتمثنل في أنسه مدير عـام يملك خلفيـة عامـة عن معظم

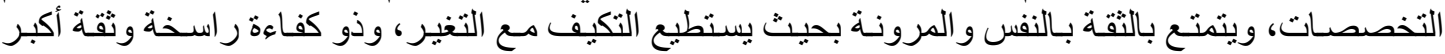

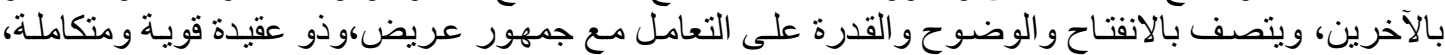

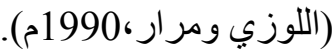

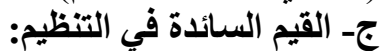

تأتي أهمية القيم في در اسة السلوك التئي التظيمي من كونها تضع الأسـاس لفهم الاتجاهـات و الحفز بالإضـافة إلى أنها

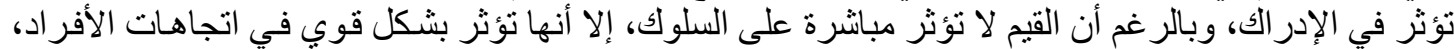

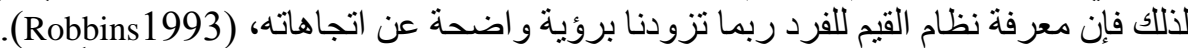

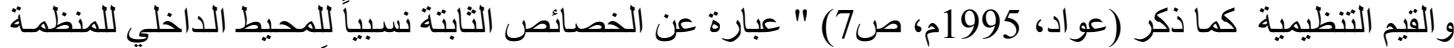

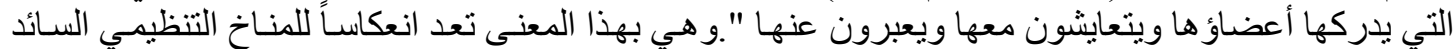

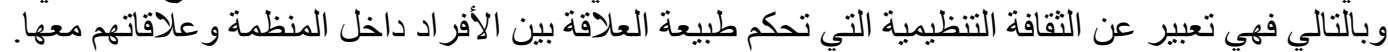
وقد أبرز روبنز (Robbins,1993)، أهم القيم التي تأخذ أولوية في معظم جهود التطوير التنظيمي بما يلي:

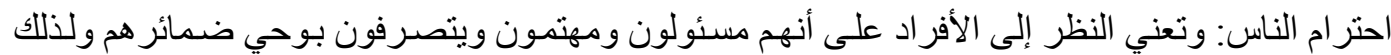

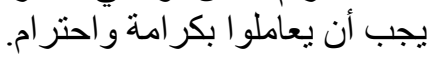

الثقة و الدعم: فالمنظمة الفاعلة و الصحية تتصف بالثقة والأصالة و الانفتاح و المناخ الداعم.

المساو اة في القوة: فالمنظمات الفاعلة لا تعطي اهتماماً للسيطرة و السلطة الهرمية بل تحاول ترسيخ العلاقات

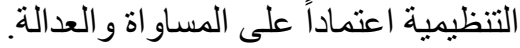

المو اجهة: يجب مناقتنة المشاكل بانفتاح ومو اجهتها لا التستر عليها و إخفائها.

المشـاركة: كلما كان الناس أكثر مشاركة بصنع القرارات التي تهمهم بشكل مباشرة كلمـا كانو ا أكثر اهتمامـاً

بتنفيذها.

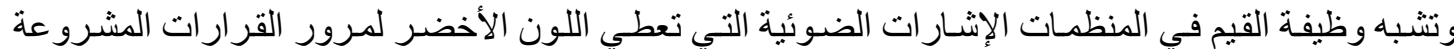

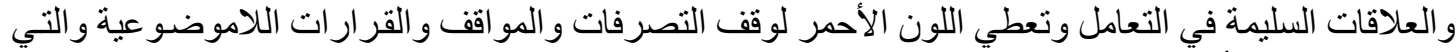

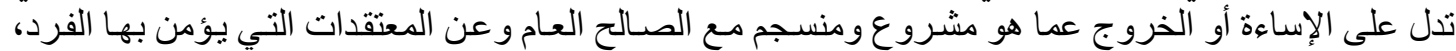

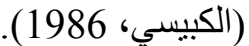

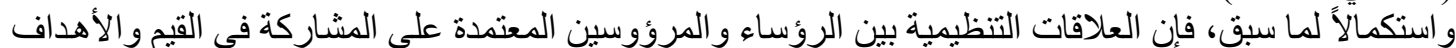

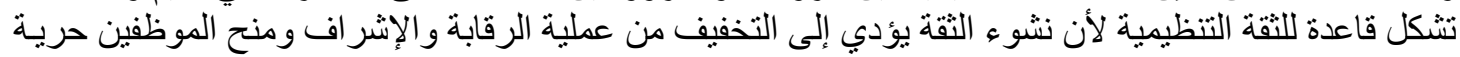

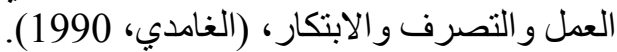
وفيما يلي توضيح لأهم عناصر بالهر بعد القيم السائدة في التنظيم:

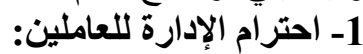

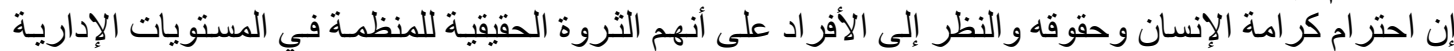
كافة من القيم المهمة في المنظمات لأنها تؤثر على الروح المعنويـة للأفر اد وتحدد مستويات ثقتهم بالإدارة.ويعد 


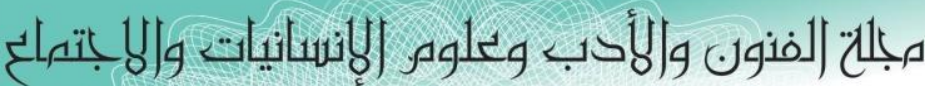

Journal of Arts, Literature, Humanities and Social Sciences

ISSN online: 2414 - 3383

ISSN print: 2616 - 3810

\section{العدد (43) ايلول -سبتمبر 2019}

الاحترام والتقدير والاهنمام بمشاعر العاملين من الحاجات التي ركز عليها " ماسلو " في نظريته هرم الحاجات كأحد العناصر الدهمة في حفز الأفر اد، (Robbins,1993).

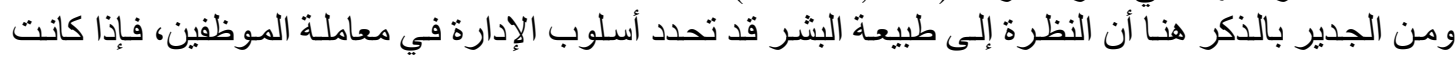

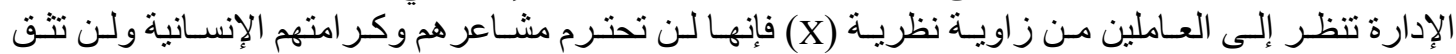

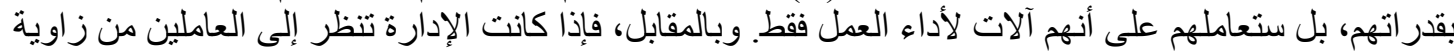

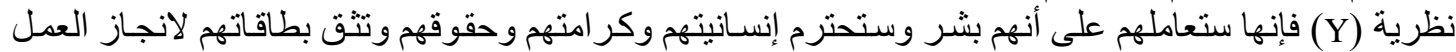

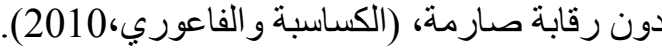
2- التعاون بين الأفراد العاملين في المنظمة:

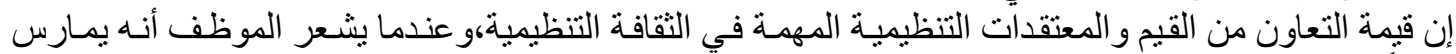

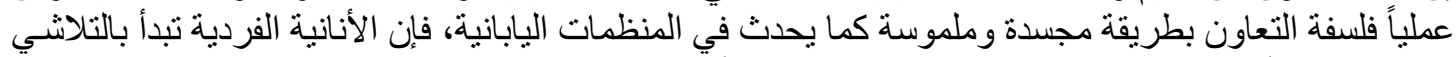

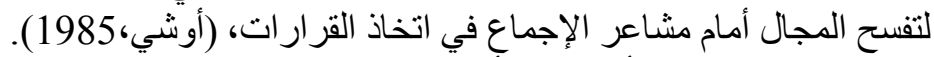

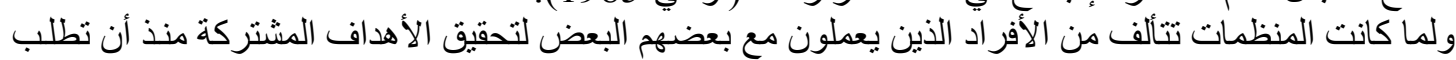

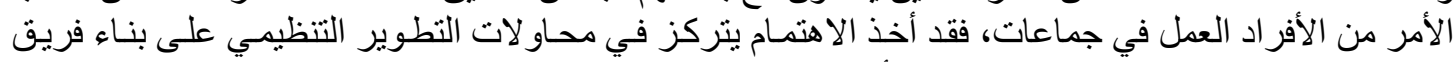

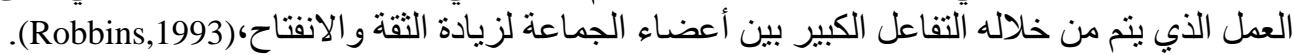

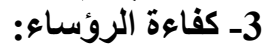

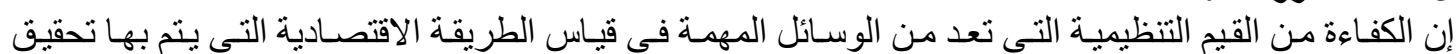

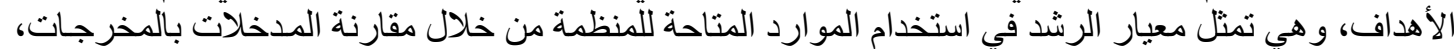

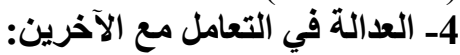

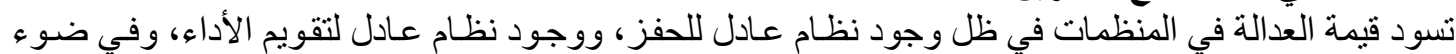

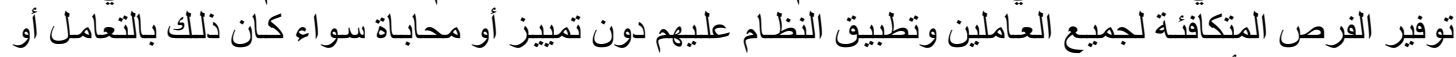

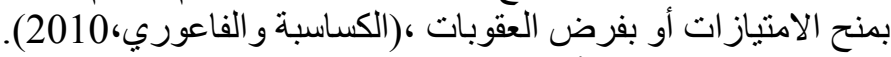

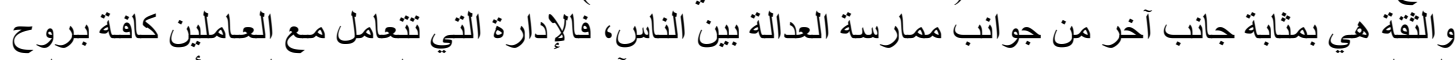

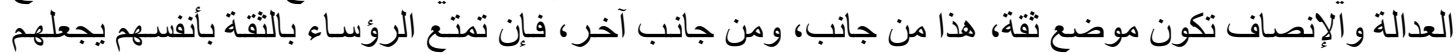

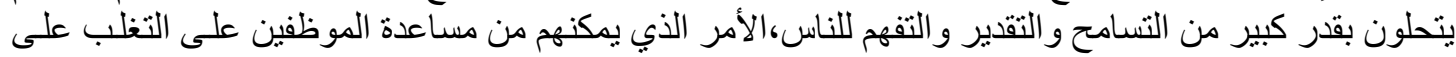

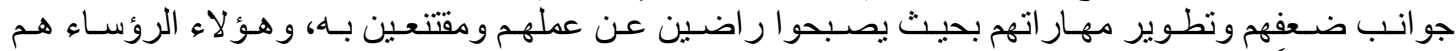

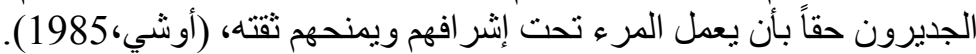
5- مواجهة المشاكل وعدم التستر عليهان التها:

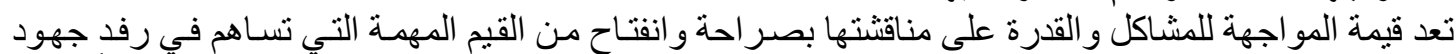

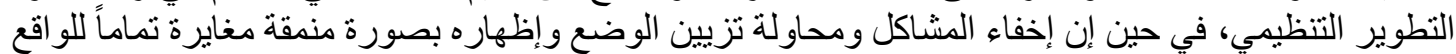

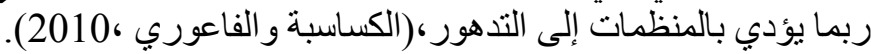

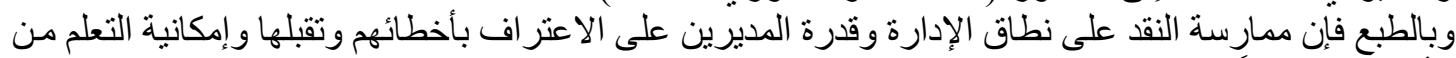

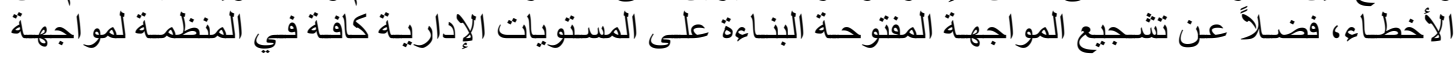

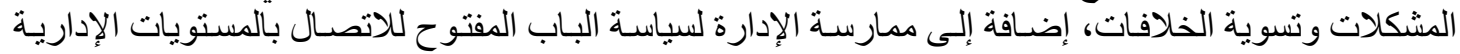

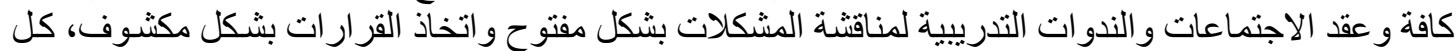

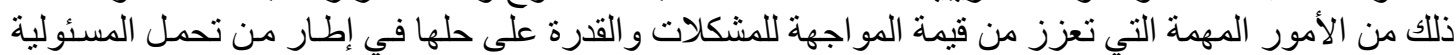
وبطريقة ديمقر اطية وبأجواء من الانفتاح والصر احة، الأمر الذي يعزز التئة المتبادلة بين الإدارة والعاملينين معها

دـ تدفق المطلومات في القتوات التنظيمية:

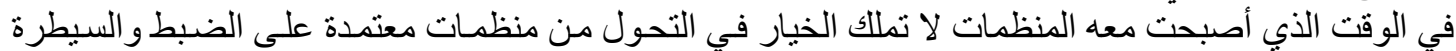

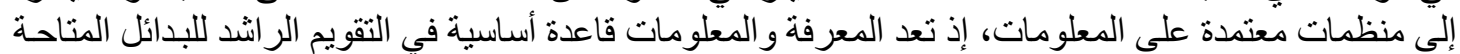

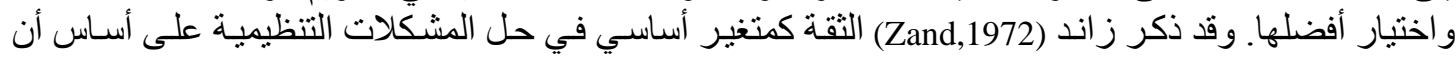


مبلحت (لفنون والأدب وعلوه الإنسانيات والبانتهاع

Journal of Arts, Literature, Humanities and Social Sciences

ISSN online: 2414 - 3383

ISSN print: 2616 - 3810

\section{أيلول - سبتمبر 2019}

العدد (43)

وجود منـاخ من الثقة يسـاعد في تبـادل المعلومـات و الأفكار و المشـاعر أو يزيد من الانفتاح و التأثثير بـالآخرين

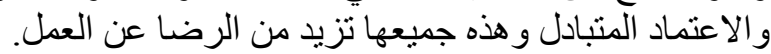

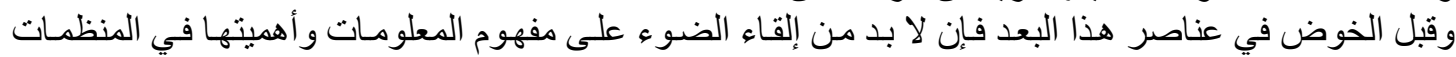

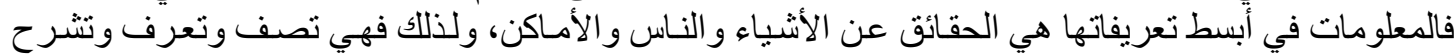

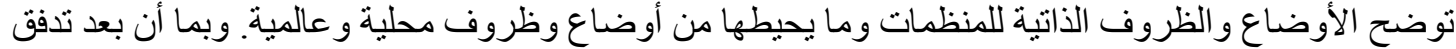

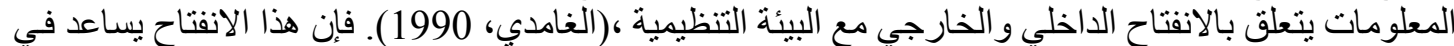

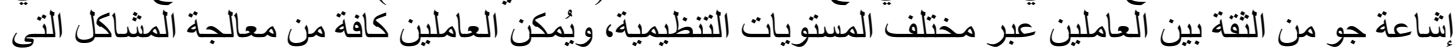

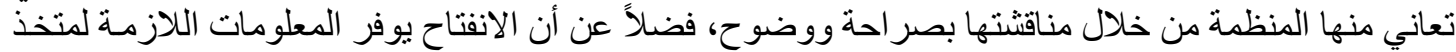
القرار بشكل مستمر دون تشويه أو تحريف ، القانيف القريوتي، 1993).

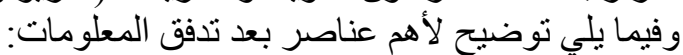

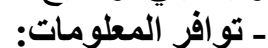

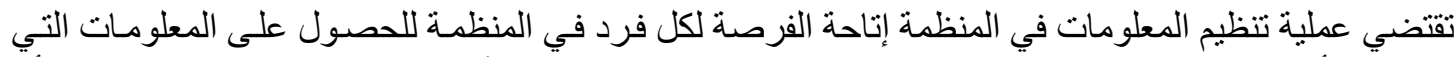

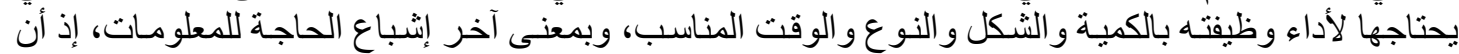

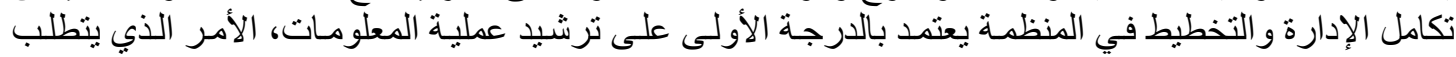

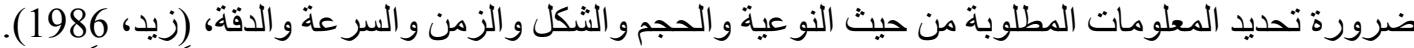

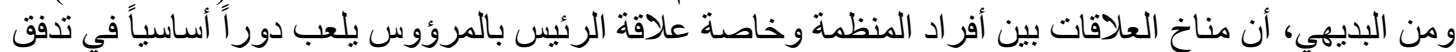

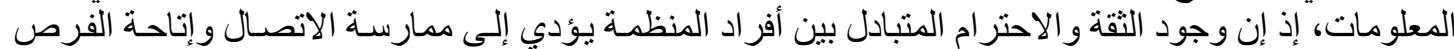

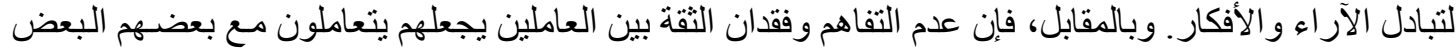

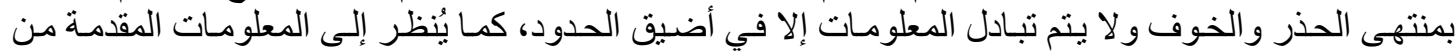

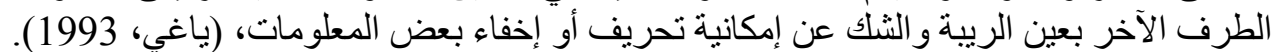

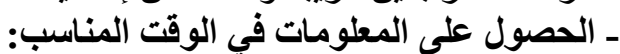

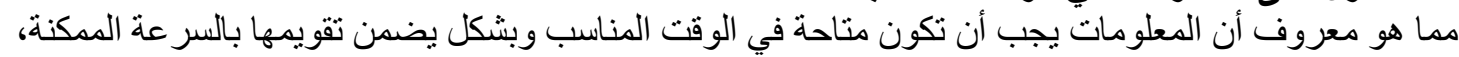

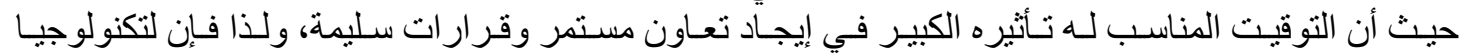

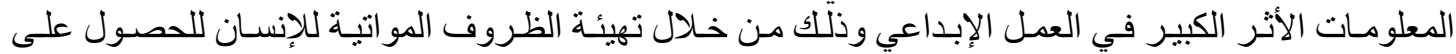

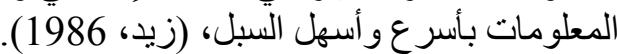

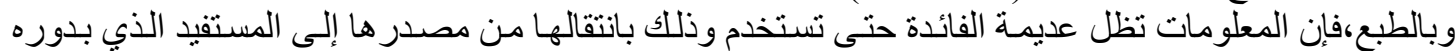

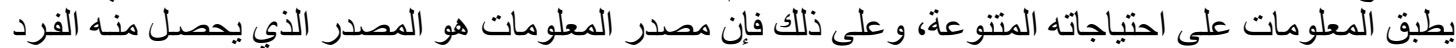

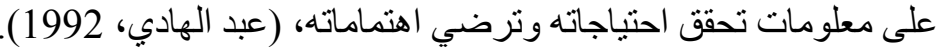

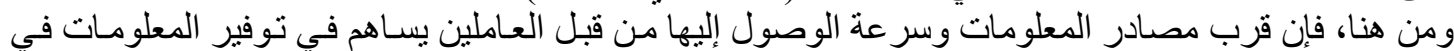

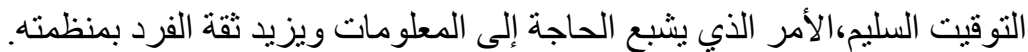

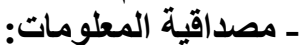

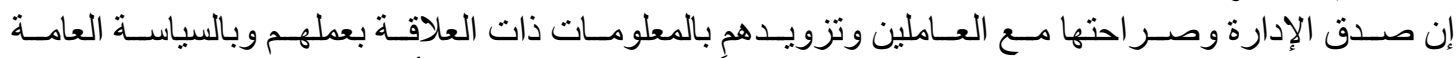

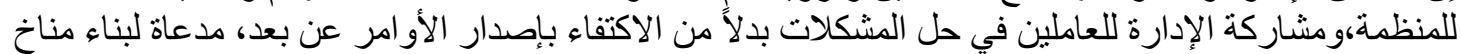

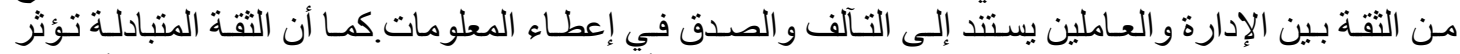

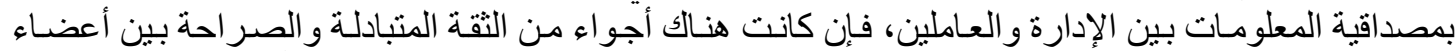

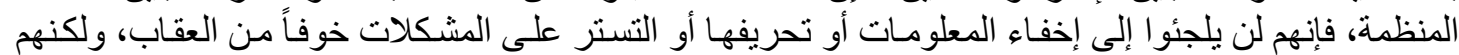
سيطرحونها للنقاش ويحاولون مو اجهتها بكل الفئ ما يملكون من طاقة جماعية.

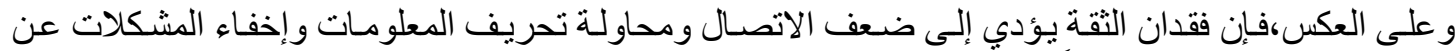

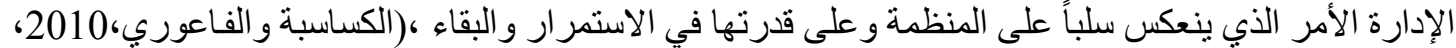

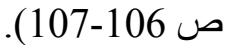




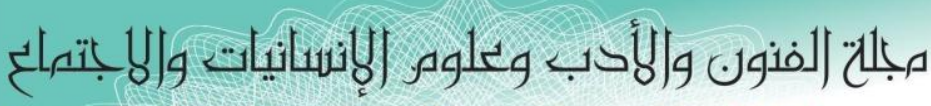
Journal of Arts, Literature, Humanities and Social Sciences

ISSN online: 2414 - 3383

ISSN print: 2616 - 3810

\section{العدد (43) ايلول - سبتمبر 2019}

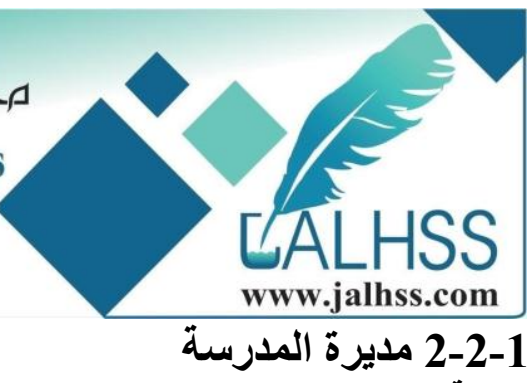

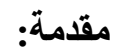

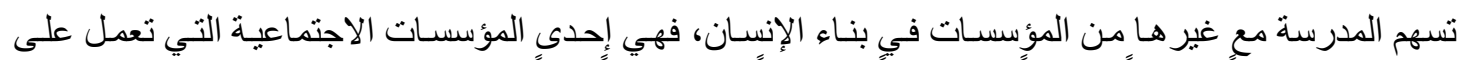

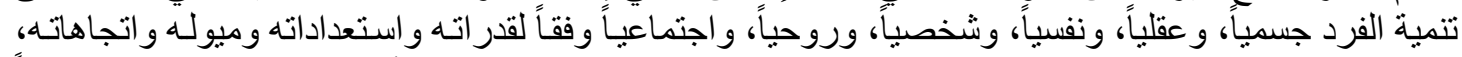

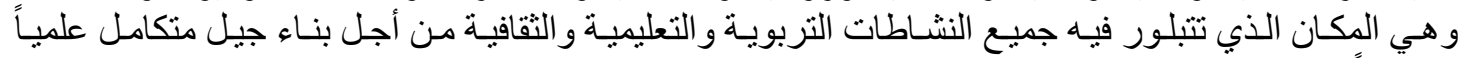

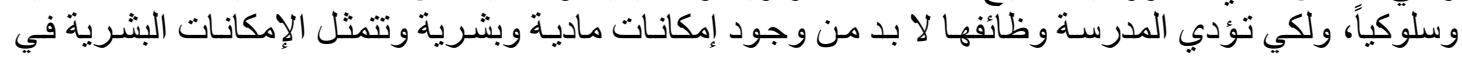

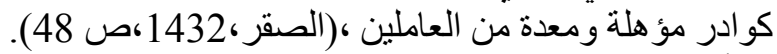

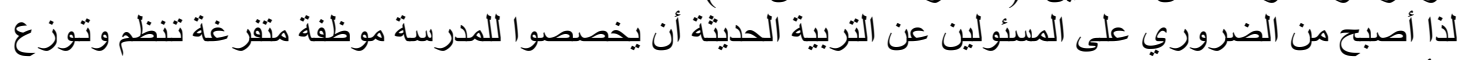

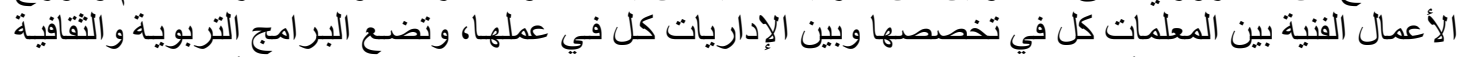

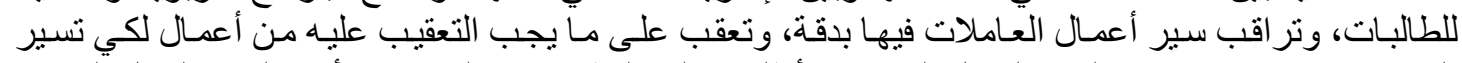

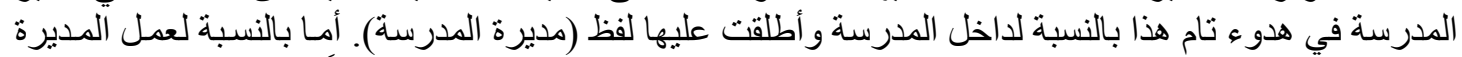

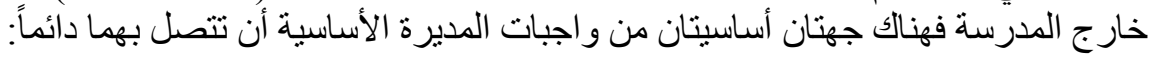
البيئة المحيطة بالمدرسة ويمثلها أولياء الأمور.

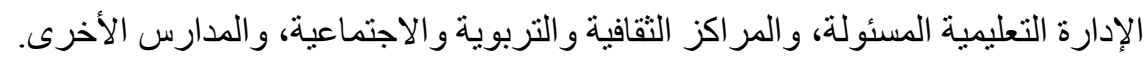

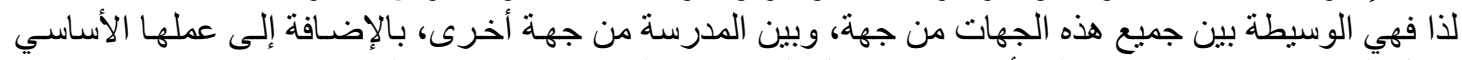

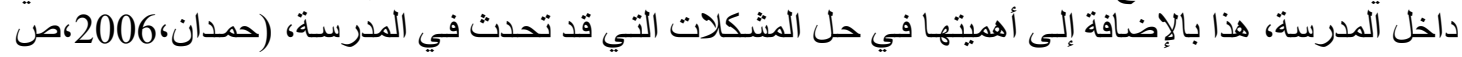

1- المقصود بمديرة المدرسة:

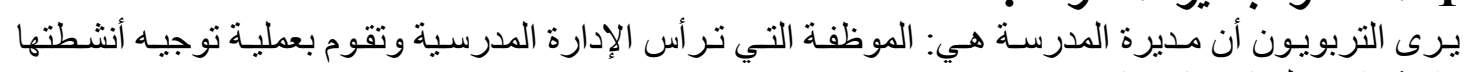

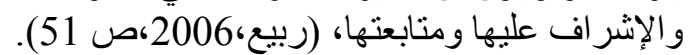

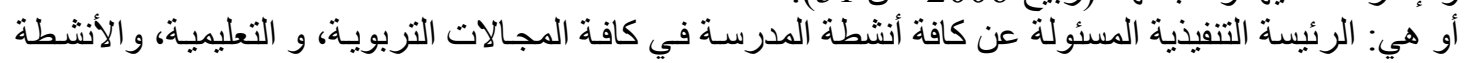

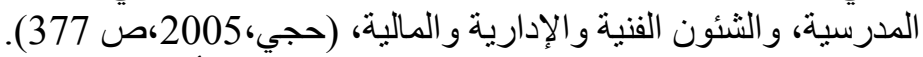

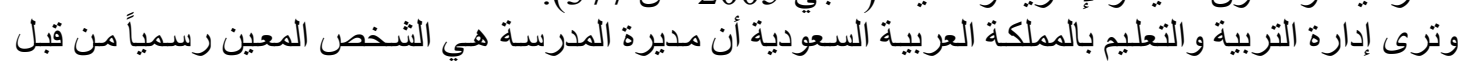

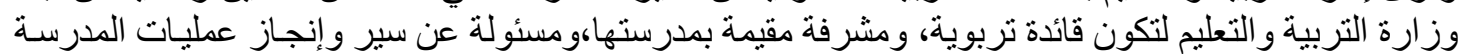

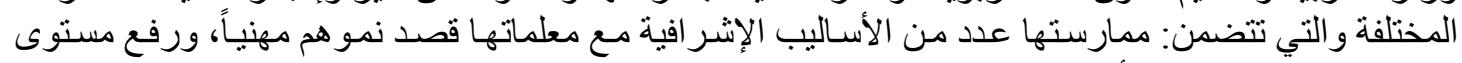

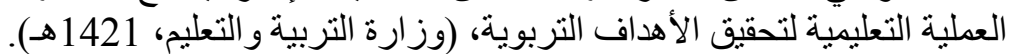

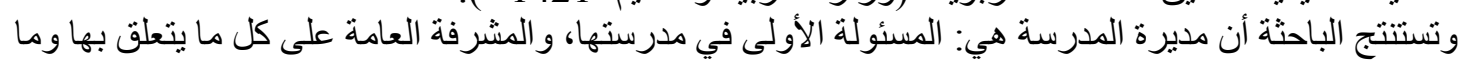

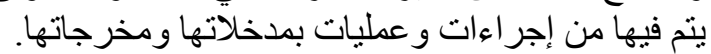

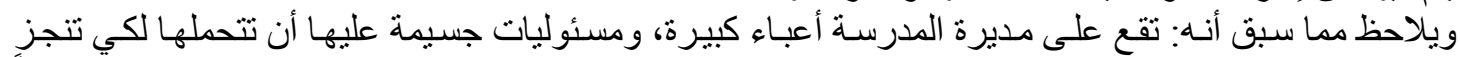

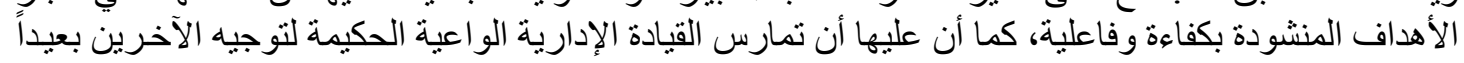

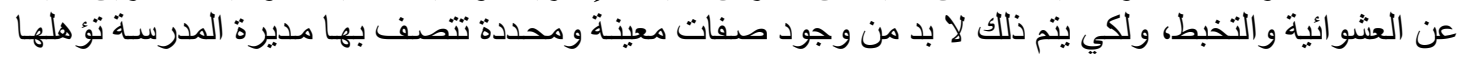
للقيام بهذا الدور، (الصقر، 1432هن).

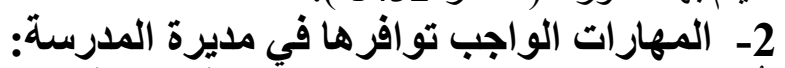

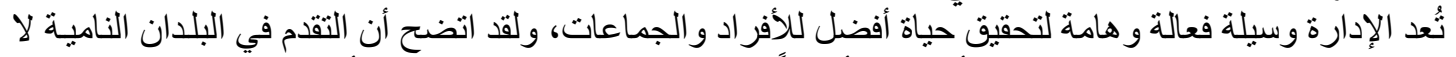

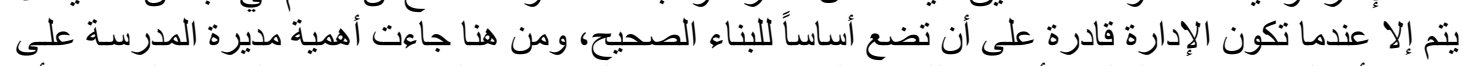

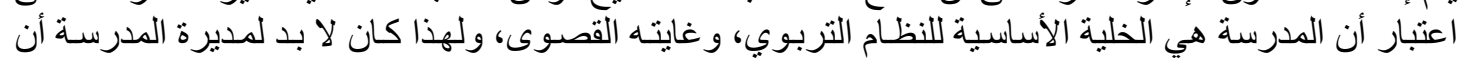

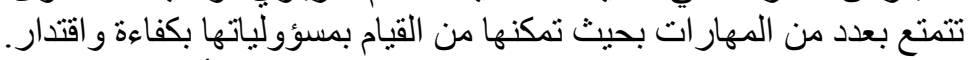

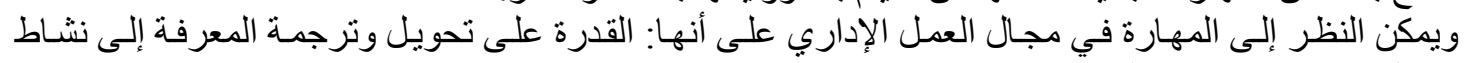

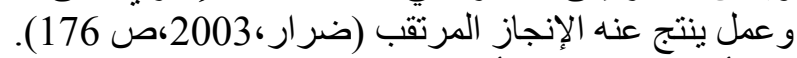

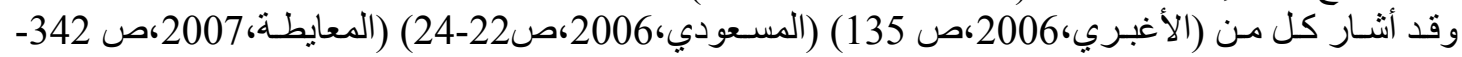

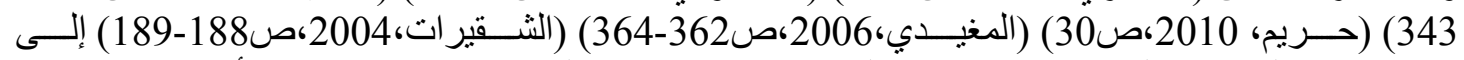
مجمو عة من المهار ات المنشودة في مدير ات المدارس عند اختيار هن لوظيفة هديرة مدرسة من أهمها: 


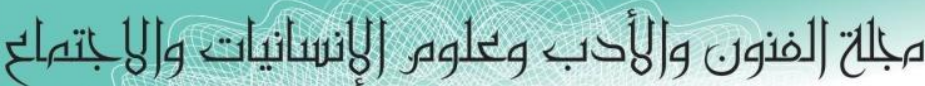

Journal of Arts, Literature, Humanities and Social Sciences

ISSN online: 2414 - 3383

ISSN print: 2616 - 3810

\section{العدد (43) ايلول - لسبتهبر 2019}

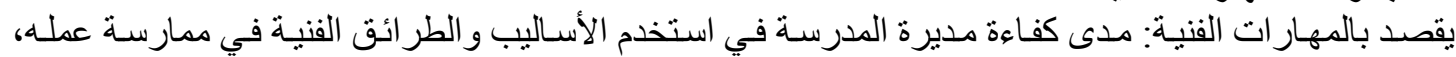

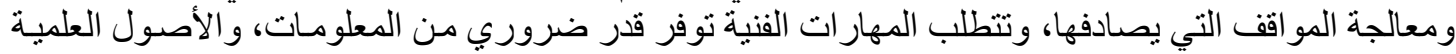
و الفنية، التي ينطلبها نجاح العمل الإداري. أو يقصد بهاً: أن يكون لدى مديرة المدرسة مهارة فنية و علمية في مجال التدريس و الإدارة تمكنها من كسب ثقالقة

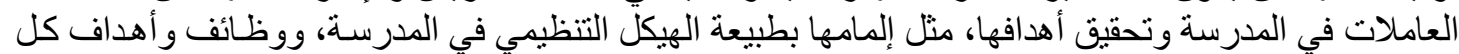

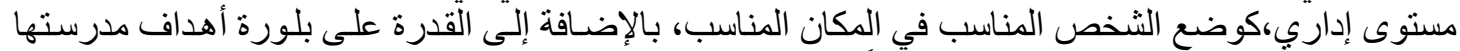

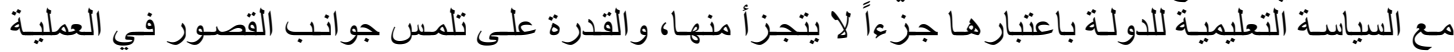

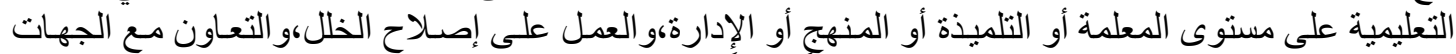

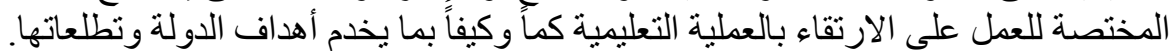

بـ مجموعة المهارات الإنسانية:

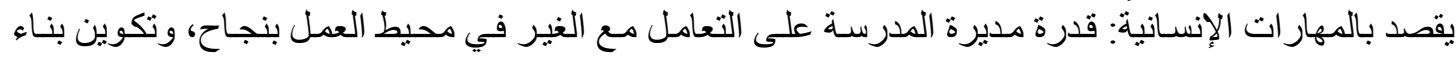

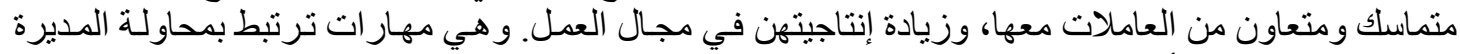

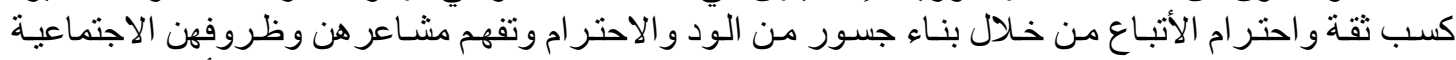

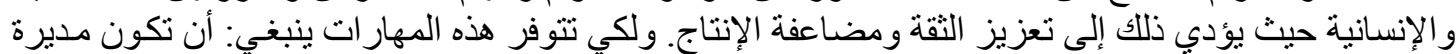

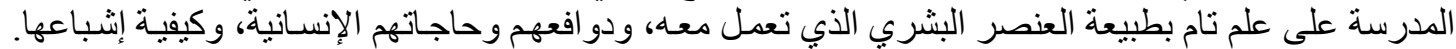

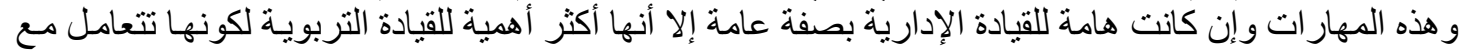

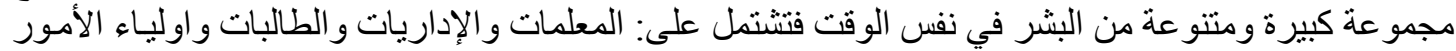

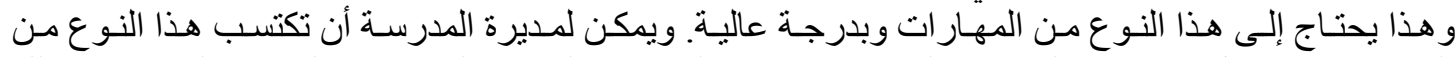

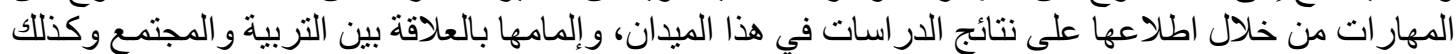

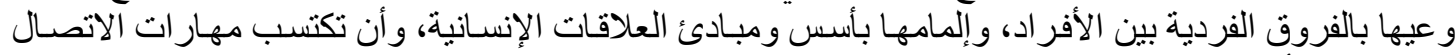

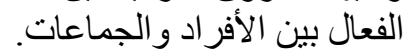
ج- مجموعة المهارات الفكرية:

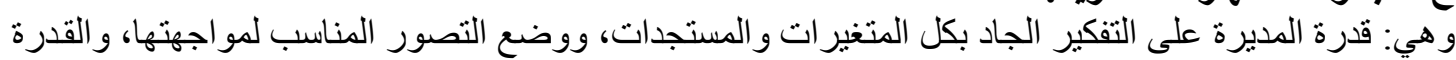

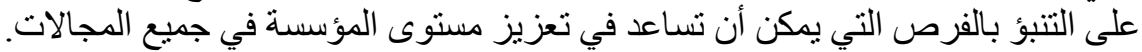

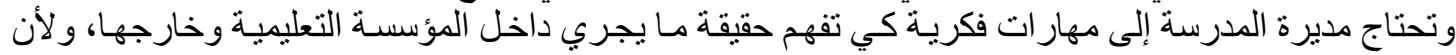

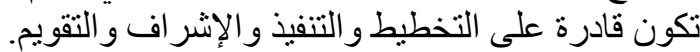

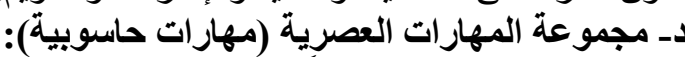

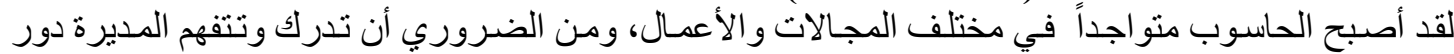

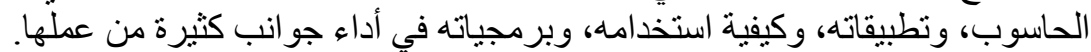

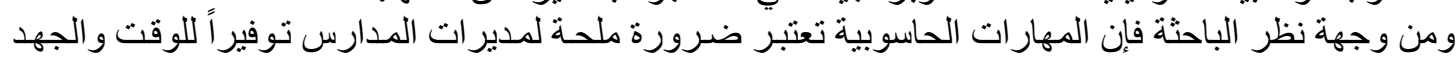

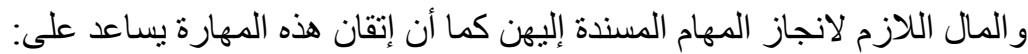

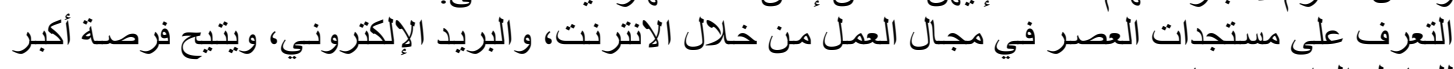
لاللتفاعل الو اعي معها. بالإضافة إلى مجمو عة أخرى من المهارات التي يجب أن تتقنها المديرة لكي تلجح وبفعالية وهي كالتالي:

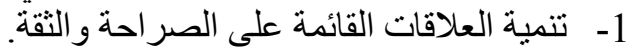

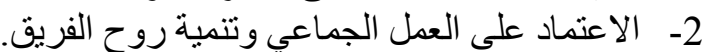

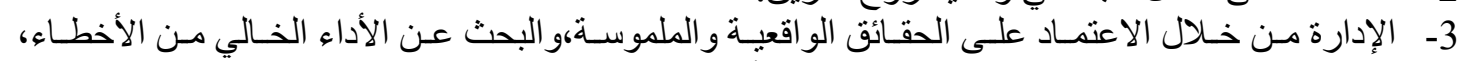
والكثف عن السبب الحقيقي للمشكلة و الحلول طويلة الإنة الأمد.

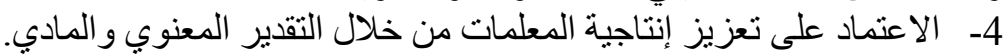

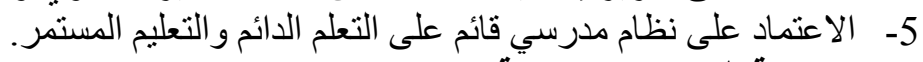
هـ مجموعة المهارات الإبداعية: يمكن إيجاز أهم المهار ات المميزة لمديرة المدية: المدرسة المبدعة بما يأتي: 


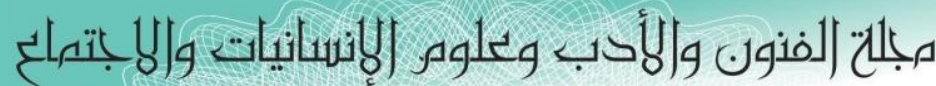

Journal of Arts, Literature, Humanities and Social Sciences

ISSN online: 2414 - 3383

ISSN print: $\mathbf{2 6 1 6 - 3 8 1 0}$

\section{العدد (43) ايلول - سبتهبر 2019}

إنجاز الأعمال الإدارية بكفاءة عالية ودون تأخير.

تقبل النقد الإيجابي بصدر رحب.

المحافظة على هدوئها في المو اقف العصيبة.

لا تتخذ قر ار اتها إلا بعد در اسة و افية، وبالاعتماد على أدلة عقلية.

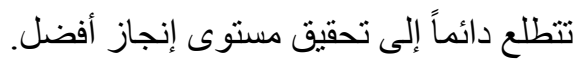

تهتم بتوثيق علاقاتها مع المجتمعين، المدرسي و المحلي.

تعمل باستمر ار على تحسين أدائها، ورفع قدر اتها بالمطالعة والتدرب، و البحث التربوي المتو اصل.

تجنتب الظلم و المحاباة.

تعمل باستمر ار على توثيق العلاقات الاجتماعية بين جميع العاملات بالمدرسة.

تصغي للآر اء المعارضة بانتباه وتدرسها.

تتجنب فرض آر ائها على الآخرين،وتعتمد أسلوب الحوار والإقناع بالأدلة العلمية.

تشارك في الأنشطة و المناسبات الاجتماعية.

3- مهام ومسؤوليات مديرة المدرسة:

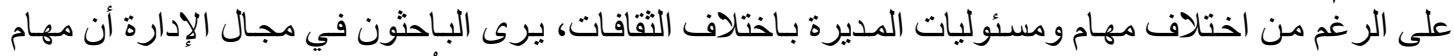

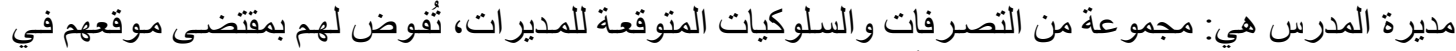

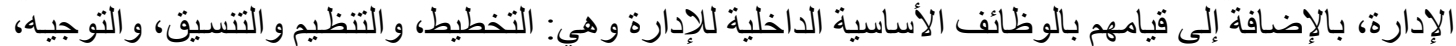

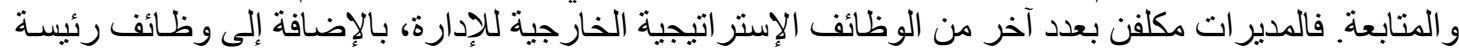

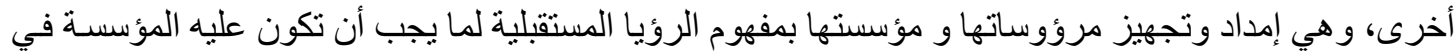

المستقبل البعيد وبالأهداف و المهام المطلوب أدوائها لتحقيق الرؤيا المستقبلية، (Nahavandi,2003,p.17).

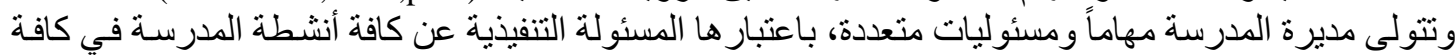

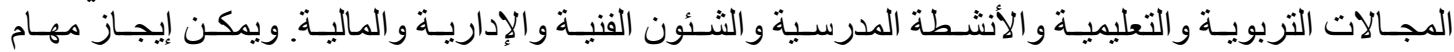

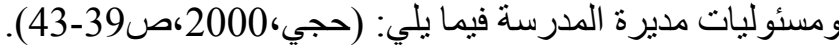

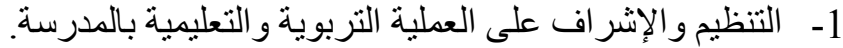
2- التنظيم و الإشـر اف علىى أعمـال وكيلات المدرسـة و المتعلقـة بمختلف أوجـهـ النشـاط المدرسـي و التعليمسي

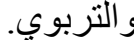
3- تحديد احتياجـات المدرسـة من القوى البشرية لاستكمال مقرر اتها الوظيفيـة، و اتخـاذ التدابير و الإجر اءات

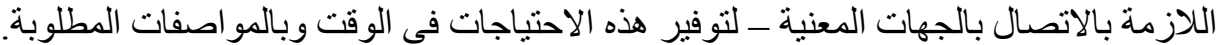
4- إعداد و اعتماد تقارير التقييم لمنسوبات المات المدرسة.

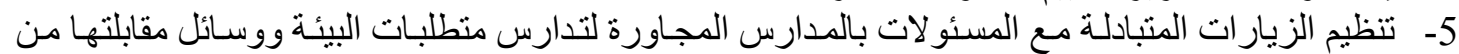
خلال الجهود المشتركة للمدارس.

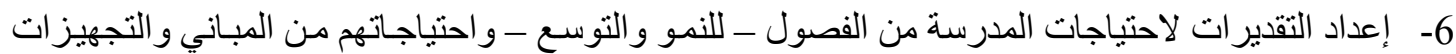

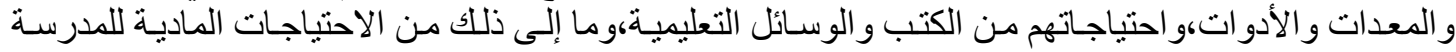
خلال السنة التالية. 7- إعداد الخطط والبر امج التنفيذية لمختلف أنشطة المدرسة و عل الأخص: قبول الطالبات الجدد، توزيعهن على الإلى الفصول، الاختبار ات الدورية و الترجات التحانات نهاية العام. 8- إعداد التقارير الدورية والبيانات الإحصائية التي تصور الموقف الجارية التهائ بالمدرسة ومدى نجاحها في تحقيق

أهداف الخطط و البر امج المقررة لمختلف أوجه النشاط بالف بالمدرسة. ـ هذا بالإضافة إلى الاهنمام بالعلاقات الإنسانية وقيادة العمل الجماعي. 


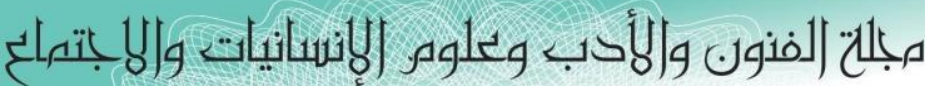

Journal of Arts, Literature, Humanities and Social Sciences

ISSN online: 2414 - 3383

ISSN print: 2616 - 3810

\section{أيلول - سبتمبر 2019}

العدد (43)

وفي ضو و ما تقام من مهام ومسئو ليات بصبح من الضروري: أن يتم الاختبار لوظيفة مديرة الددرسة ممن تتوفر فيهز الثروط و المو اصفات المحددة.

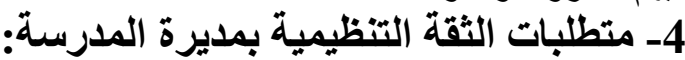

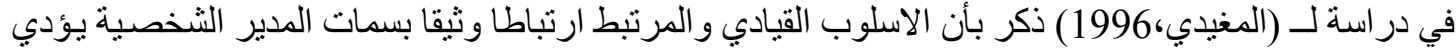

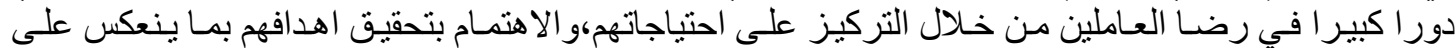

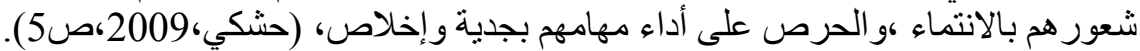

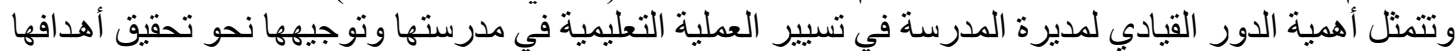

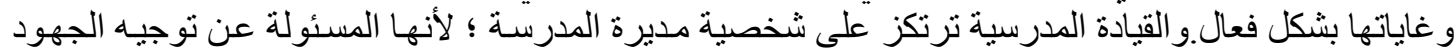

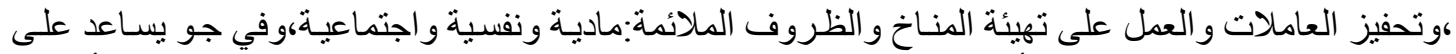

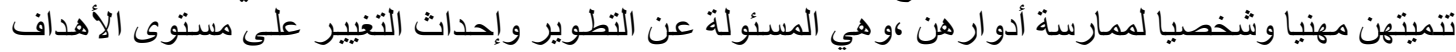

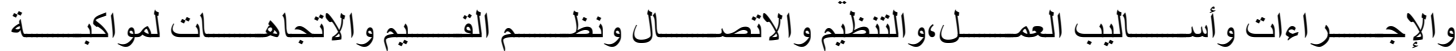
التغير ات, (Purkey\&Smith,1983).

وقد اورد موش (Moshe,1991) وتحت مجالات محددة المهام الإداريـة المنوطة بمديرة المدرسـة من حيث تحديد

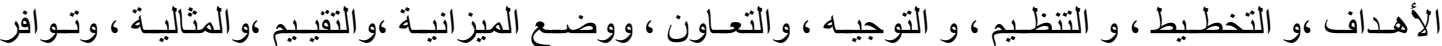

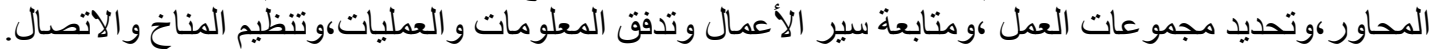

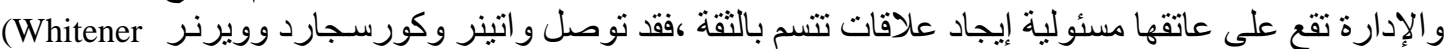
Korsgard \&Werner,1998)

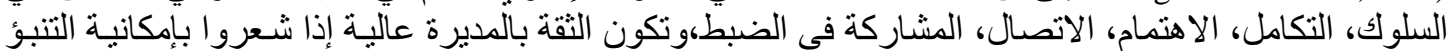

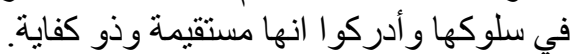

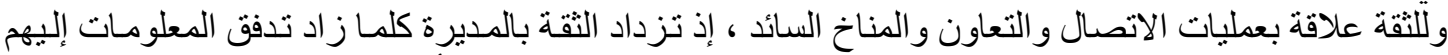

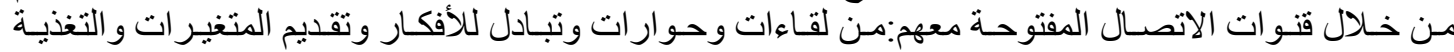
الر اجعة حول القرار ات، (Moran \& Hoy,2000).

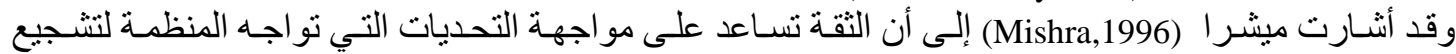

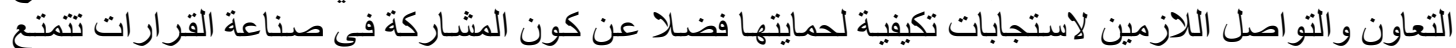

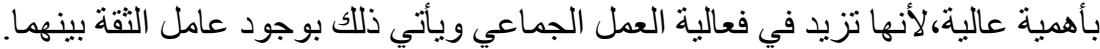

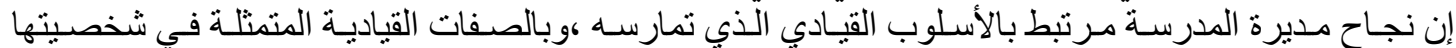

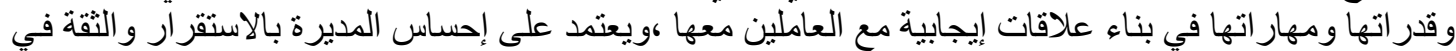

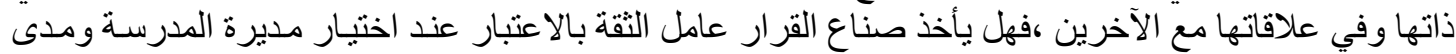

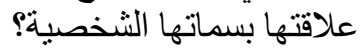

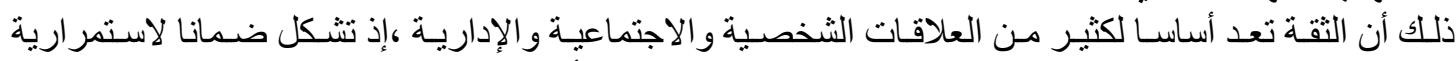

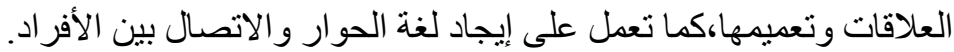

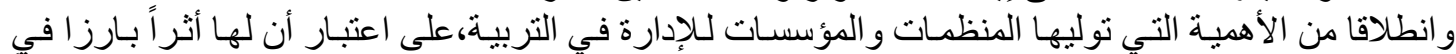

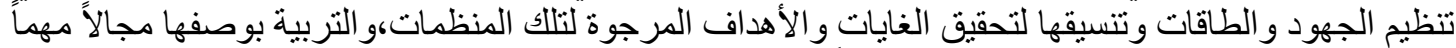

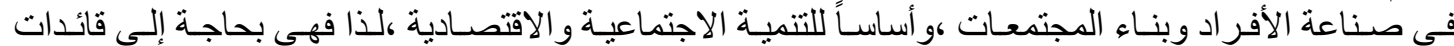

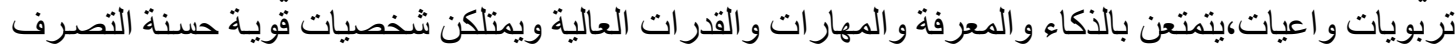
ترتبط بعلاقات إنسانية مع الآخرين علاقات تقوم على الثقة و احتر ام الآخر كوتمتلك من سمات الثات الثخصية مايؤ هلها

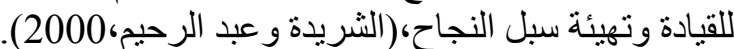

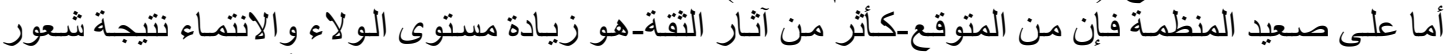

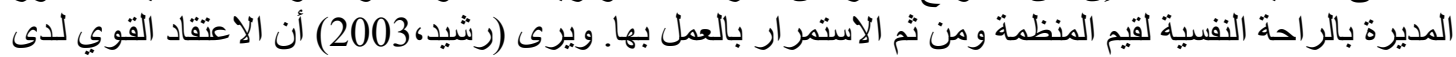

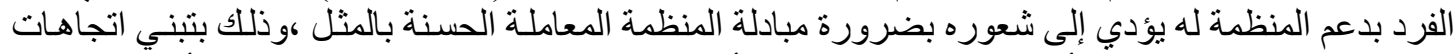

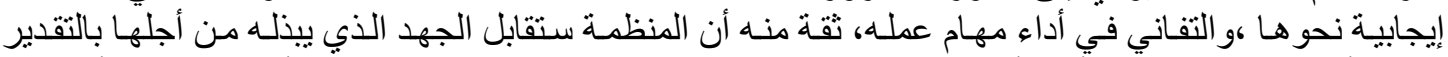

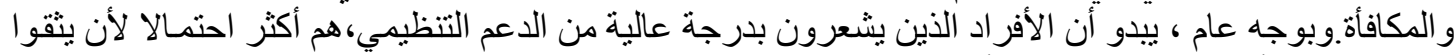

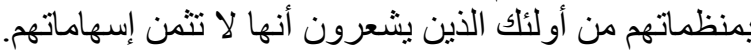




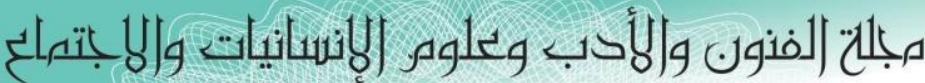

Journal of Arts, Literature, Humanities and Social Sciences

ISSN online: 2414 - 3383

ISSN print: 2616 - 3810

\section{أيلول - سبتمبر 2019}

العدد (43)

بعد أن تم استعر اض الجزء النظري المتعلق بالثقة التنظيمية بأنو اعها وابعادها، وبعد الإنشارة إلى الدور الهام

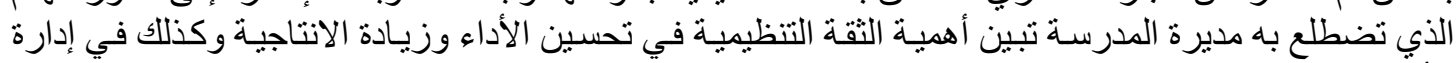

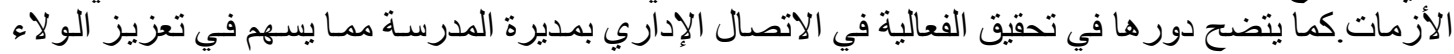
التنظيمي وبناء العلاقات ورفع الروات في الروح المعنوية لإى العاملين. 2-2 2 2 2 الدراسات السابقة:

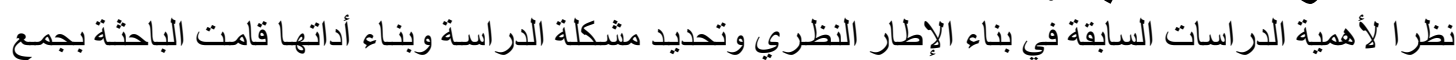

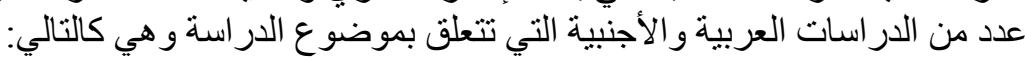

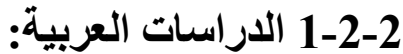

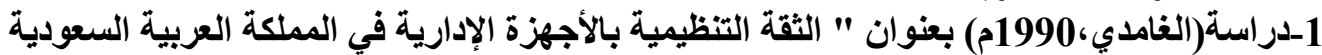

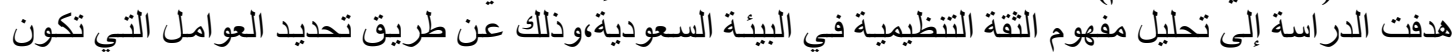

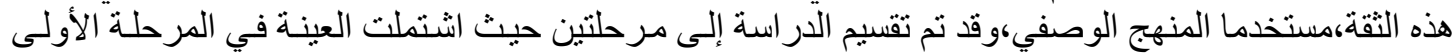

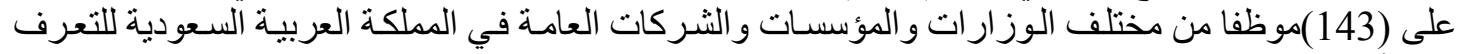

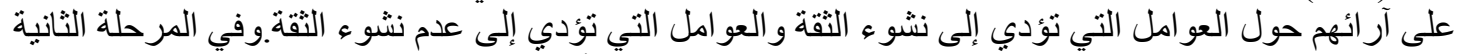

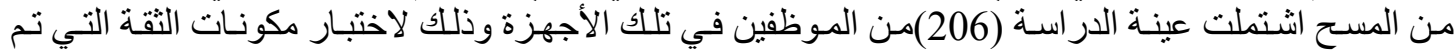

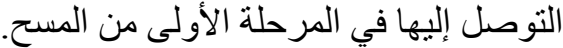
وقد توصلت الدر اسة للنتائج التالية:

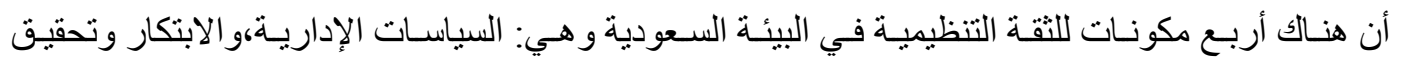
الذاتهو القيم السائدة وتو افر المعلومات ،و هذه المكونات تحتوي على عناصر فر عية أخرى.

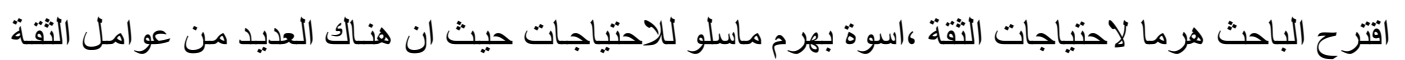
وما يندرج تحنها من عناصر نتأثر بمتغير ات المستوى التعليمي،و عدد سنو ات الخدمة،و العمر ،و المرتبة الوظيفية. 2- دراسـة (الحوامدة والكساسبة،2000م) بعنوان" أثر الثقة التنظيمية والمشـاركة في صنع القرارات على

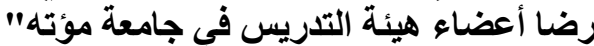

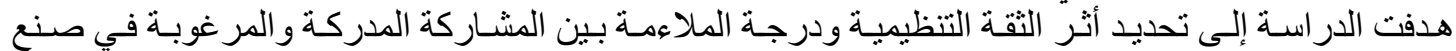

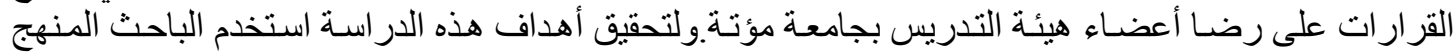
الوصفي وقد تم تطوير استبانة وتم توزيعها على عينـة الدراسـة (314) عضو هيئة تدريس من أصلـ الصل (370) عضو هيئة تدريس. وكان من أهم النتائج التي توصلت إليها الدر اسة ما يلي:

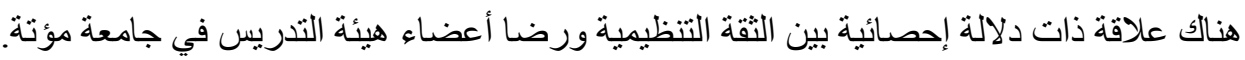

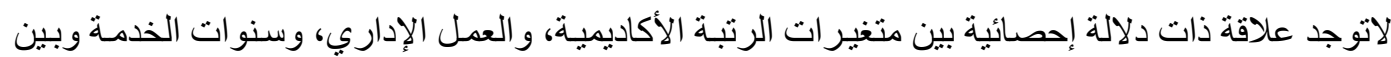

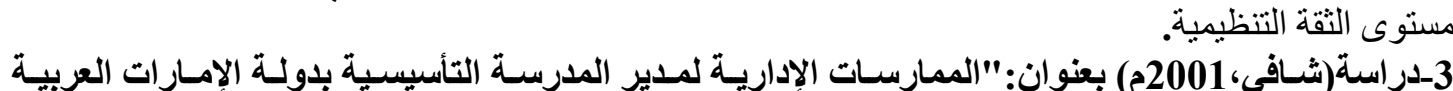

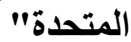

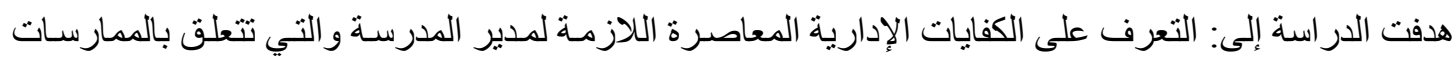

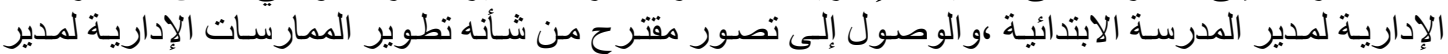

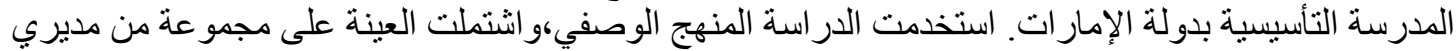

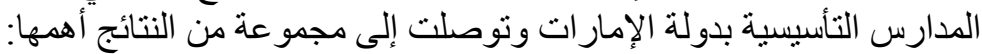

أن مدير المدرسة لا يعطى الصلاحيات التي تمكنه من اتخاذ القرارات المناسبة لتسيير العملية التعليمية. أن الإمكانات المادية والبشرية التي توفر ها الوز ارة لا تساعد على الإعداد لبر امج و أنشطة لا صفية المية مفيدة. 


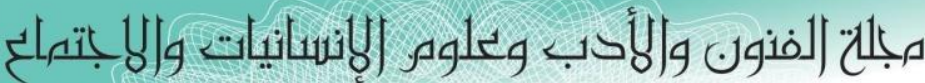

Journal of Arts, Literature, Humanities and Social Sciences

ISSN online: 2414 - 3383

ISSN print: 2616 - 3810

\section{العدد (43) ايلول -سبتهبر 2019}

ـأن جميع مديري المدارس يخضـعون لنفس المعايير في الاختبار و الإعداد و التدريب و لا يوجد بر امج تدريبية

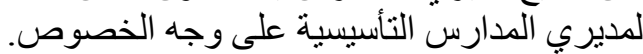

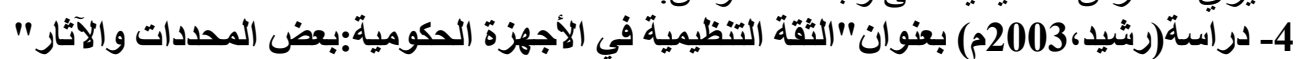

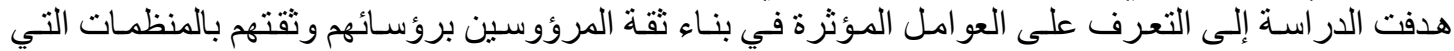

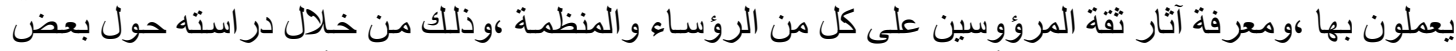

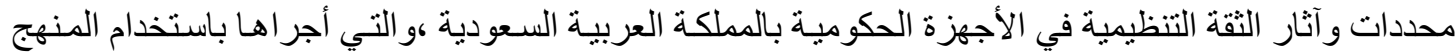

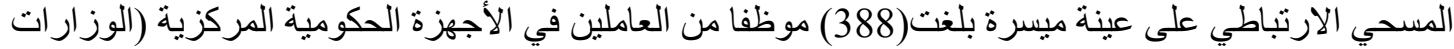

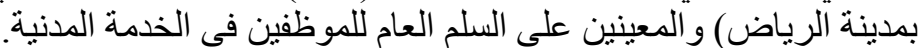

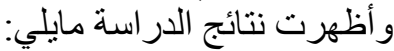

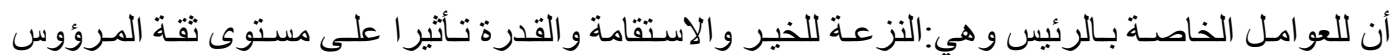

بالرئيس.

كما أن للثقة بالرئيس تأثير ا على الرضا عن الرئيس وسلوك المو اطنة التنظيمية.

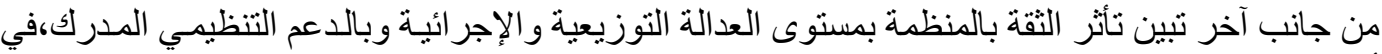

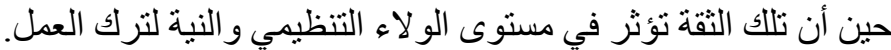

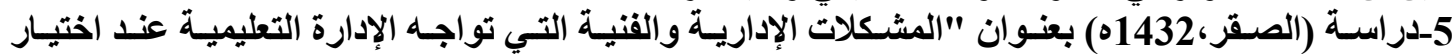

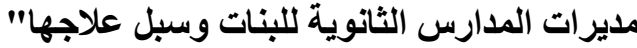

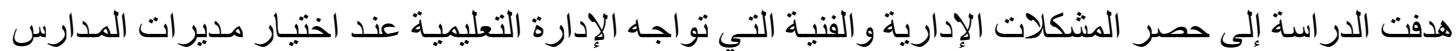

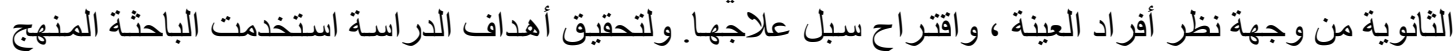

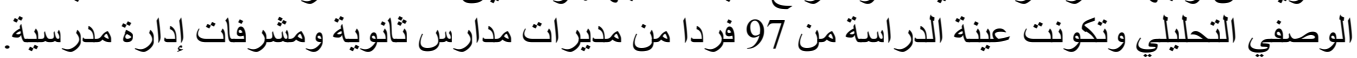
وتوصلت الدر استة للنتائج التالية: حصلت مجمو عة من المشكلات الإدارية و الفنية على مستوى تو اجد بدرجة كبيرة الأمر الذي يتطلب تظافر الجهود لحها.

اتفق أفر اد العينة على أهمية السياسات المقترحة في التخطيط ،وتفويض الصناحيات التيات لمديرة المدرسة.

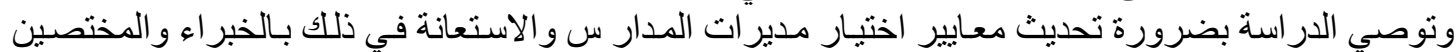

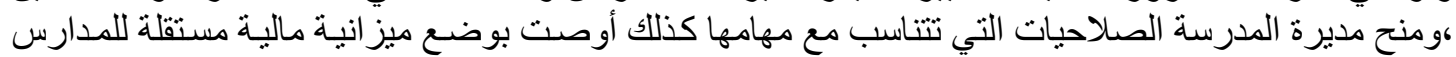

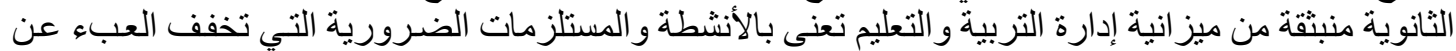

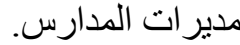

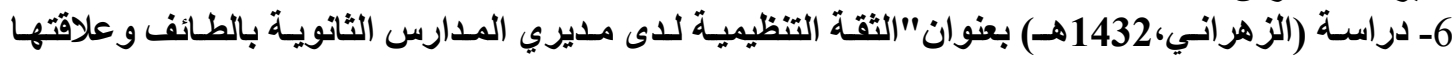

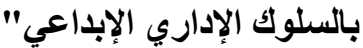

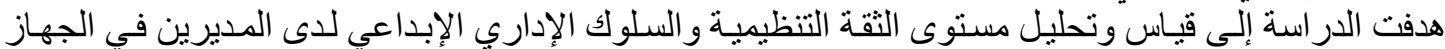

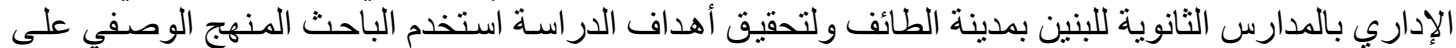
عينة بلغت (83)مدير ا. ظهرت نتائج الدر اسة ما يلي: اني

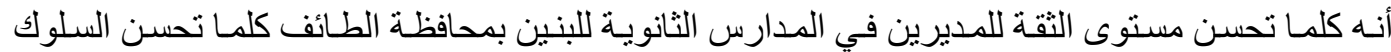

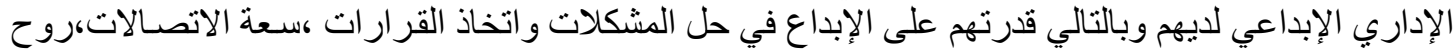

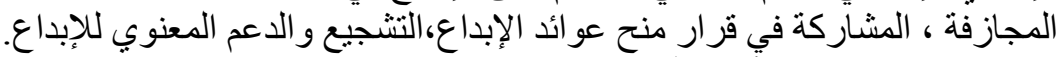

2-2-2

7- دراسة قام بها جلبيرت (Gilbert,1998) بعنوان "الأثقة في الإدارة العليا في القطاع العام "

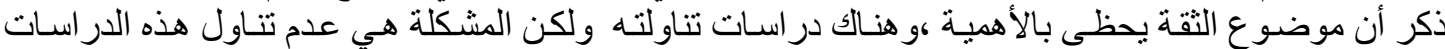

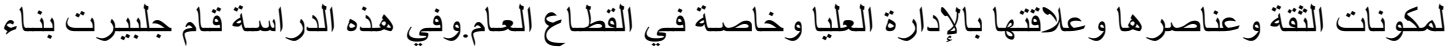
على در اسة ومر اجعة الأدبيات السابقة باقتر اح نموذج يحدد العناصر الأساسية السابقة و النتائج المنوقعة للتقة في 


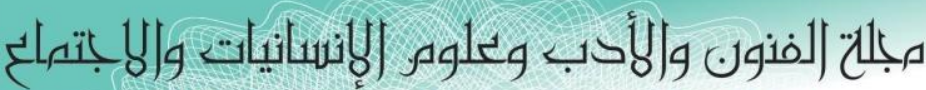

Journal of Arts, Literature, Humanities and Social Sciences

ISSN online: 2414 - 3383

ISSN print: 2616 - 3810

\section{أيلول - سبتمبر 2019}

العدد (43)

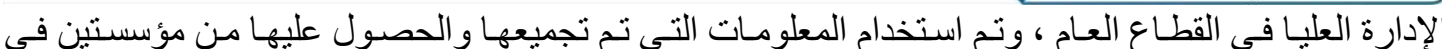

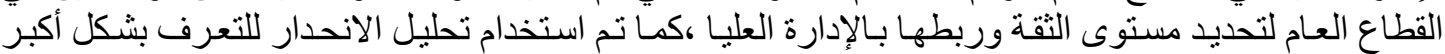

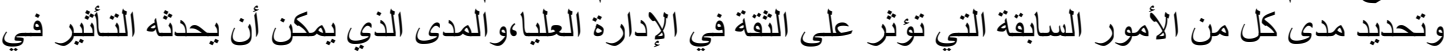
الإدارة العليا على النتائج. وأظهرت الدر اسة النتائج التالية:

أن عملية الاتصال الفعالة في المنظمة و العدالة الإجر ائية ودعم المنظمـات و الرضـا و الأمسان الوظيفي يمكنها أن تتنبأ بمدى الثقة في الإدارة العلّيا في القطاع العالهي العام.

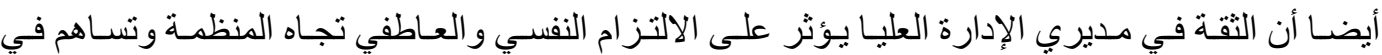

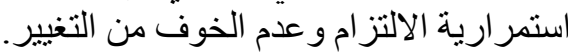

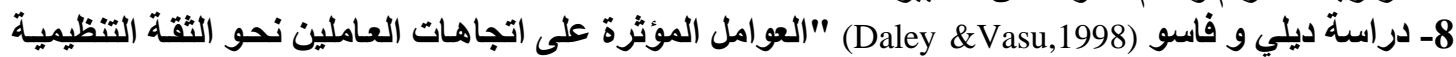
بالإدارة العليا" دراليات

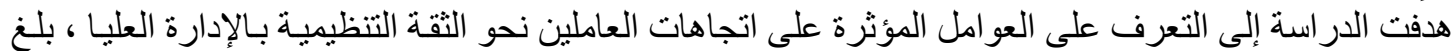

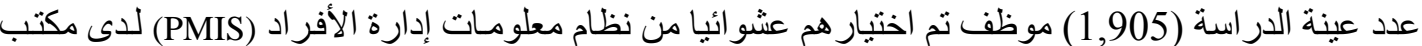
(OSP) بو لاية كارولينا الثمالية.

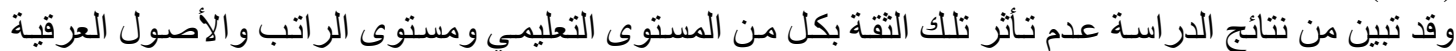

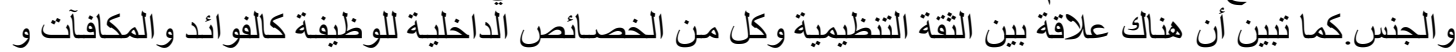

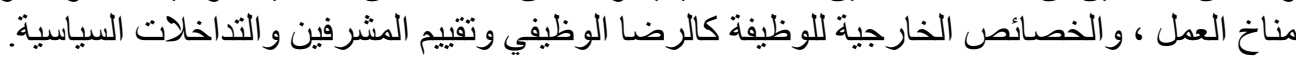

3-2-2

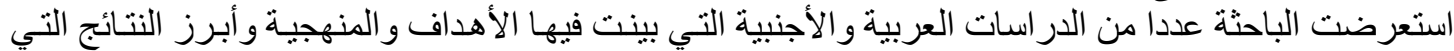

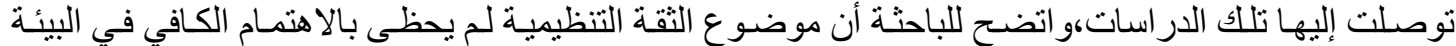

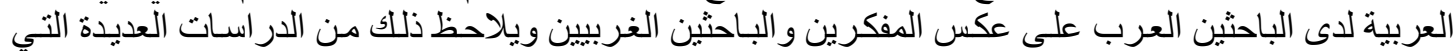

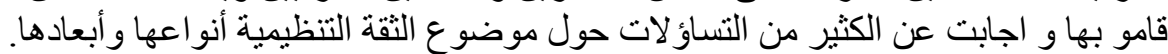

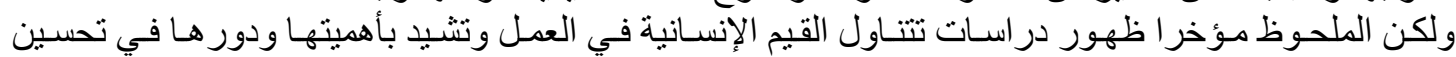

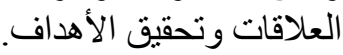

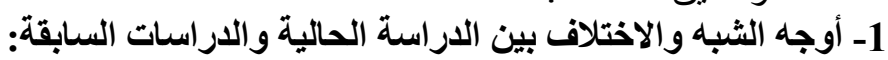

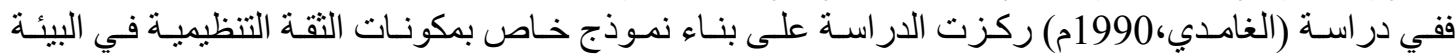

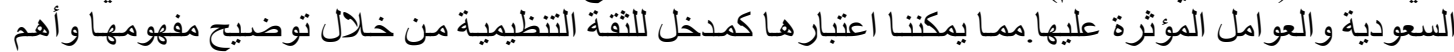

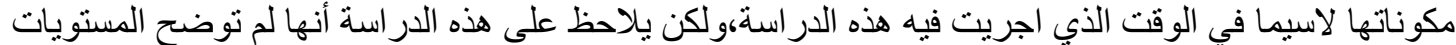

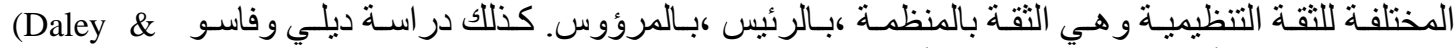
Vasu,1998) ودر اسة جيلبرت (Gilbert,1998) التي اقترح فيها الباحث نموذج يحدد العناصر الأساسية للثقة في الإدارة العليـا

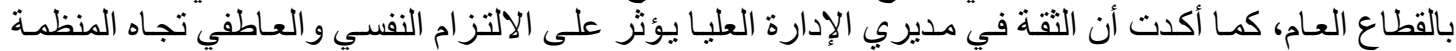

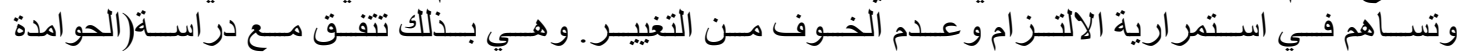

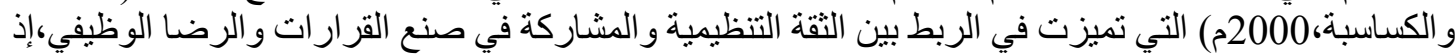

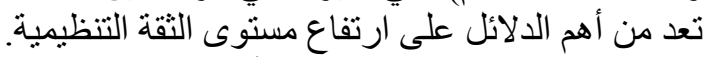

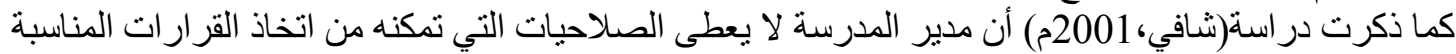

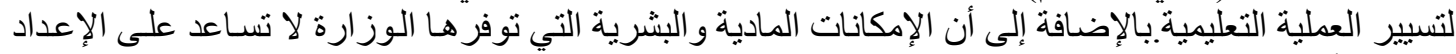
لبر امج و أنشطة لاصفية الصفية مفيدة.

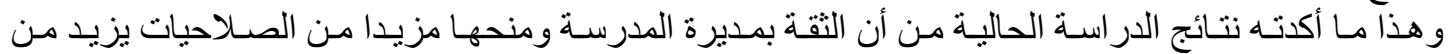

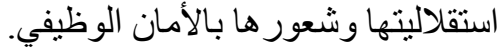

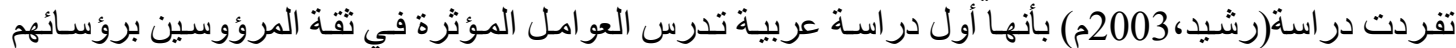
و ثقتهم بالمنظمة وآثار هذه الثقة.ولكن الملاحظ على هذه الدراسة كثرة الاستدلال والنقل من الدراستات الأجنبية. 


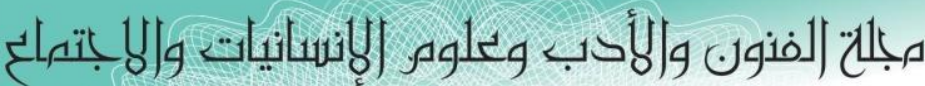

Journal of Arts, Literature, Humanities and Social Sciences

ISSN online: 2414 - 3383

ISSN print: 2616 - 3810

\section{أيلول - سبتهبر 2019}

العدد (43)

وتمبزت در اسة (الزهر اني،1433ه) بالربط بين أبعاد الثقة التنظيمية و أبعاد السلوك الإداري الإبداعي ، ولكن

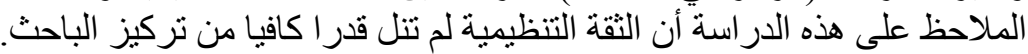

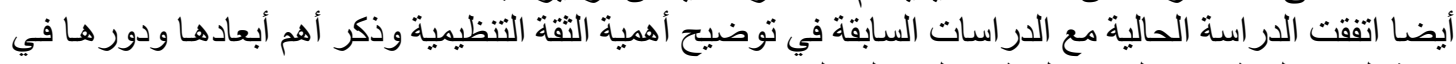

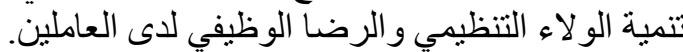
فاتفقت مع دراسة جلييرت (Gilbert,1998) بأن الاتصـال الفعال و الرضـا و الأمسان الوظيفي تعد مؤشر ات هامـة المستوى الثقة التنظيمية.

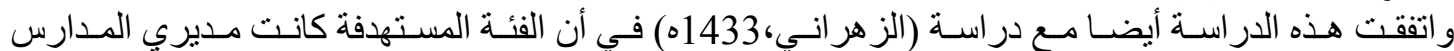

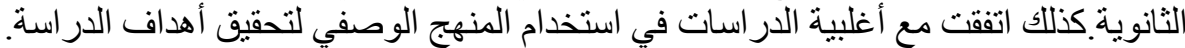

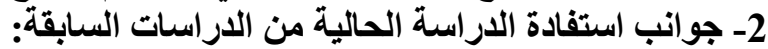

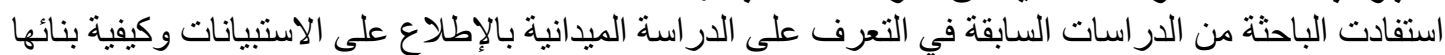

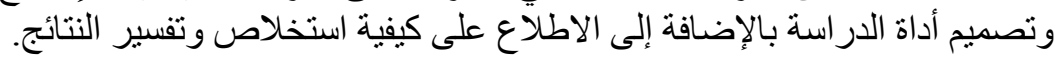

3- جوانب تفردت بها الدراسة الحالية عن الاراسات السابقة:

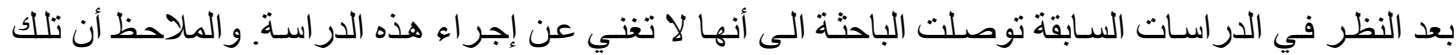

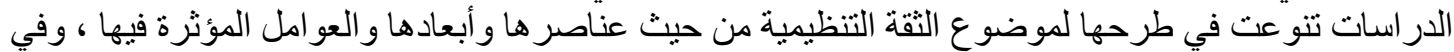

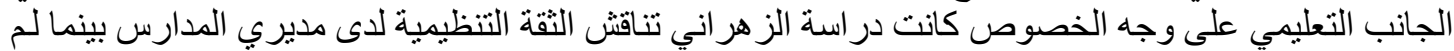

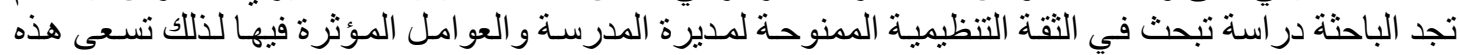

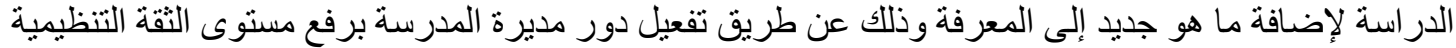
بها ومعرفة العو امل المؤثرة على ذلكألك.

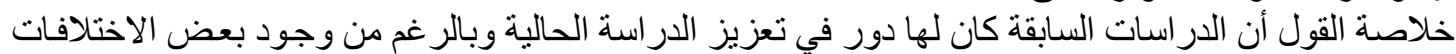

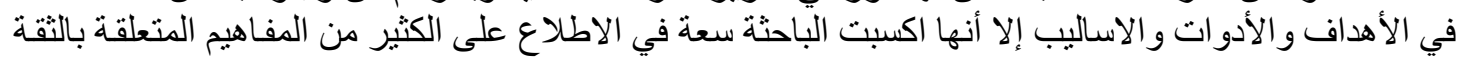

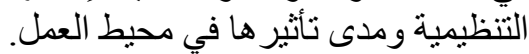

\section{الفصل الثالث \\ منهجية الدراسة وإجراءاتها}

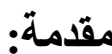

يعتبر هذا الفصل بداية الجانب الميداني من الدراسة ،وفيما يلي وصف الخطوات التي قامت بها الباحثة لتحقيق أهداف الدراسة و الإجابة عن أسئلتها.

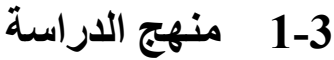

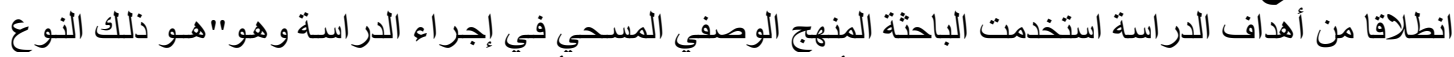

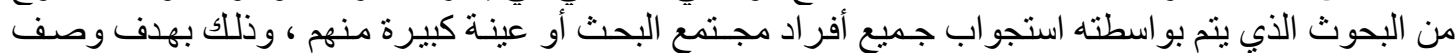

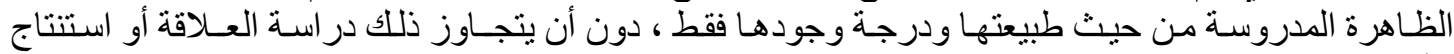

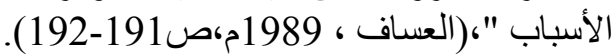

حيث تم دراسة مستوى الثقة التنظيمية بمديرات المدارس الثانوية ،من خلال: تطبيق أداة الدراسة ،ثم تحليل البيانات،وتفسير النتائج التي تم النوصن التوصل إليها.

2-3 مجتمع الاراسة و عينتها:

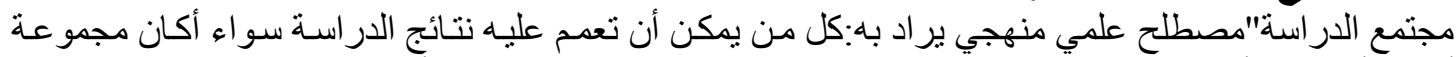

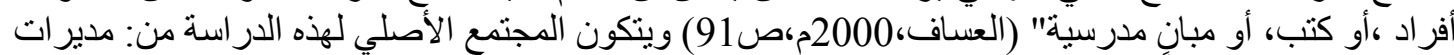

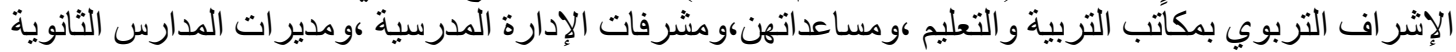

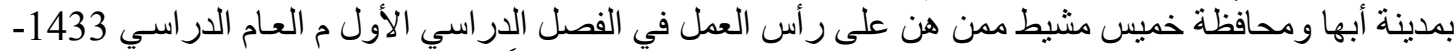
1434 هـ وقد تم استخدام اسلوب المسح الثامل للحصول على العينة نظر ال لصغر مجتمع الدراسة. 
مبلحت (لفنون والأدب وعلوه الإنسانيات والبانتهاع Journal of Arts, Literature, Humanities and Social Sciences

ISSN online: 2414 - 3383

ISSN print: 2616 - 3810

\section{العدد (43) ايلول - سبتمبر 2019}

LALLHSS

www.jalhss.com

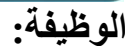

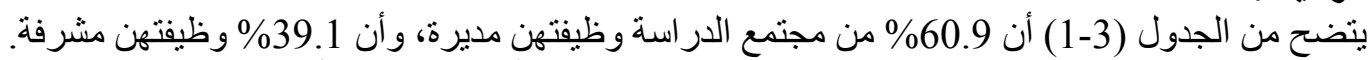
جدول (1-3) توزيع مجتمع الدراسة حسب الوظيفة

\begin{tabular}{|c|c|c|}
\hline النسبة (\%) & التكر ار & الوظيفة \\
\hline 39.1 & 25 & مشرفة \\
\hline 60.9 & 39 & مديرة \\
\hline 100 & 64 & المجموع \\
\hline
\end{tabular}

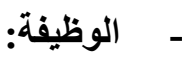

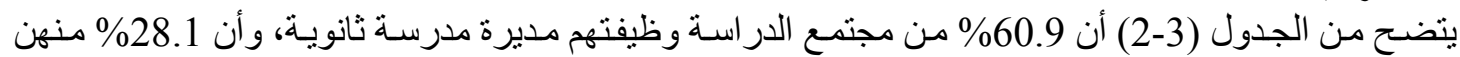

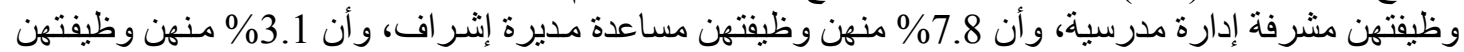

جدول (2-3) توزيع مجتمع الدراسة حسب الوظيفة

\begin{tabular}{|c|c|c|}
\hline النسبة (\%) & التكرار & الوظيفة \\
\hline 3.1 & 2 & مديرة إثر اف \\
\hline 7.8 & 5 & مساعدة مديرة إشر اف \\
\hline 28.1 & 18 & مشرفة إدارة مدرسية \\
\hline 60.9 & 39 & مديرة مدرسة ثانوية \\
\hline 100 & 64 & المجموع \\
\hline
\end{tabular}

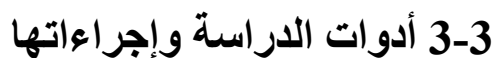

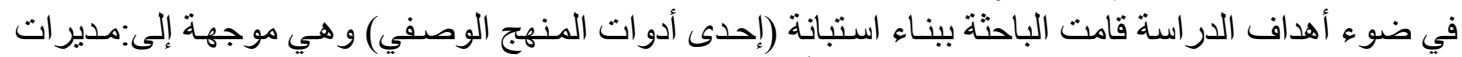

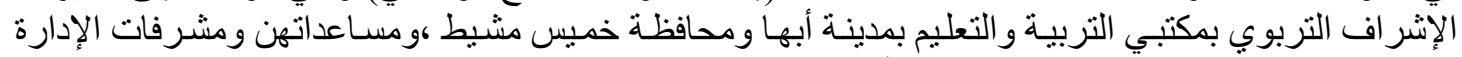

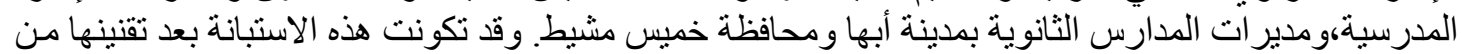

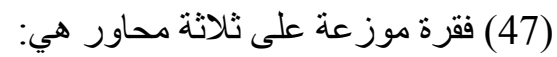

مستوى الثقة التنظيمية بمديرات المدارس الثانوية.

معوقات الثقة التنظيمية بمدير ات المدارس الثانوية.

متطلبات تعزيز الثقة التنظيمية بمدير ات المدارس الثانوية.

1- 1 - 1 إعداد الاستبانة:

مرت عملية بناء الاستبانة من قبل الباحثة بالتتسيق المستمر مع المشرفة على الدر استة بعدة مر احل:

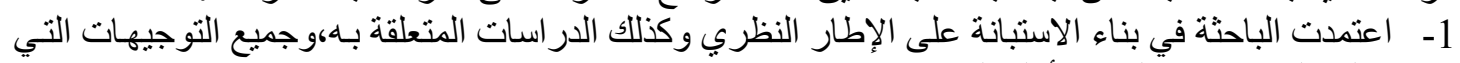
حدنتها لها المشرفة في البناء الأولي للاستبانة.

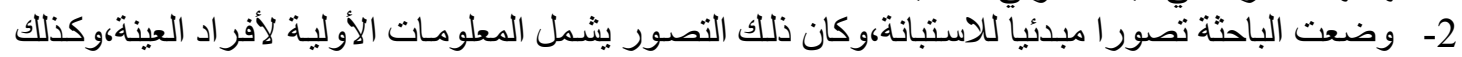
الفقر ات الخاصة بمحاور الدراستة

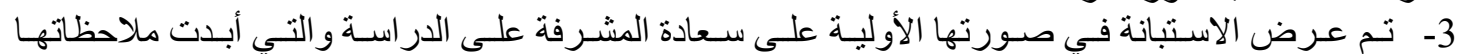

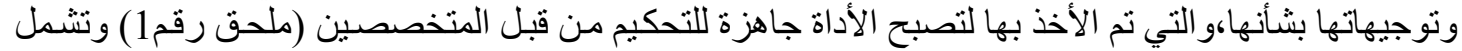
الجزء الأول: ويتضمن معلومات أولية عن المستجيية تشمل:العمل الحالي،المؤهل العلمي،عدد سنو ات الخبرة في

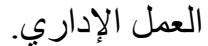
الجزء الثاني: اشتمل على محاور الاستبانة التي تم تقسيمها إلى ثلاثة محاور رئيسية،وهي: المحور الأول:مستوى الثقة التنظيمية بمديرات المدارس الثانوية. 


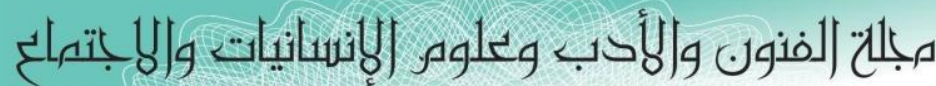

Journal of Arts, Literature, Humanities and Social Sciences

ISSN online: 2414 - 3383

ISSN print: 2616 - 3810

\section{العدد (43) ايلول -سبتمبر 2019}

المحور الثاني:معوقات الثقة التنظيمية بمديرات المدارس الثانوية.

المحور الثالث:منطلبات تعزيز الثقة التنظيمية بمديرات المدارس الثانوية.

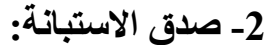

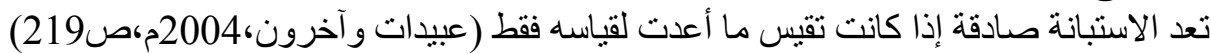

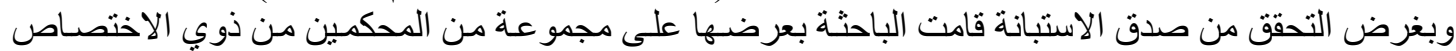

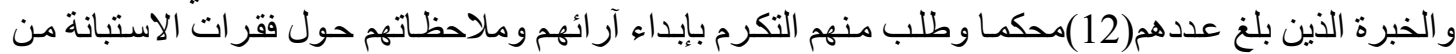

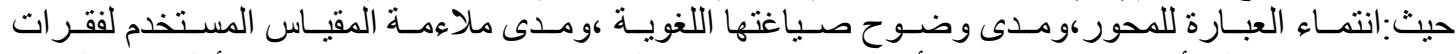

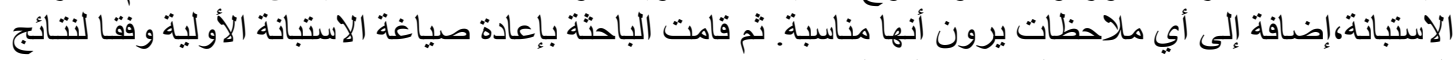

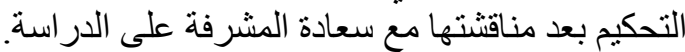

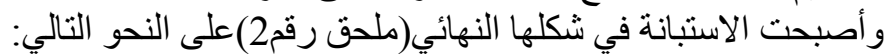

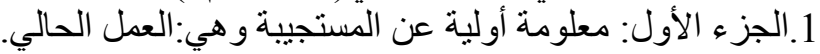

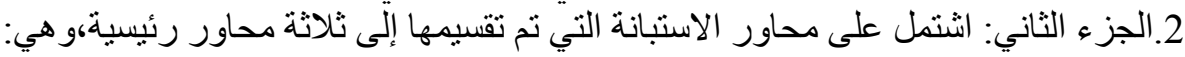
المحور الأول:مستوى الثقة التنظيمية بمدير ات المدارس الثنانوية ويندر ج تحتها أبعاد الثقة التنظيمية الأربعة.

المحور الثاني:معوقات الثقة التنظيمية بمديرات المدارس الثانوية.

المحور الثالث:منطلبات تعزيز الثقة التنظيمية بمدير ات المدارس الثانوية.

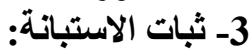

تم حساب ثبات الأداة باستخدام معادلة ألفا كرونباخ ويوضح الجدول رقم (3-3) قيمة معامل الثبات لكل جز ء من

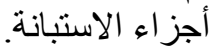

جدول (3-3) قيم معاملات الثبات لكل محور من محاور الاستبانة

\begin{tabular}{|c|c|}
\hline 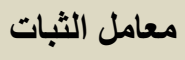 & 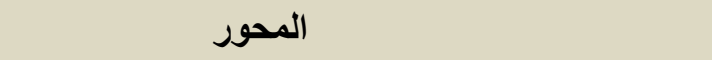 \\
\hline 0.7966 & السياسات الإدارية \\
\hline 0.7903 & فرص الابتكار وتحقيق الذات \\
\hline 0.7862 & القيم التنظيمية \\
\hline 0.7902 & تدفق المعلومات في القنو ات التنظيمية \\
\hline 0.7500 & معوقات الثقة التنظيمية بمديرة المدرسة الثانوية \\
\hline 0.8146 & منطلبات تعزيز الثقة التنظيمية بمديرة المدرسة الثانوية \\
\hline
\end{tabular}

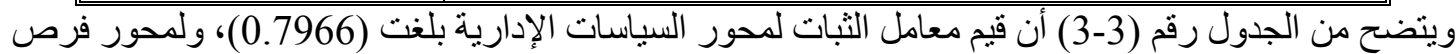

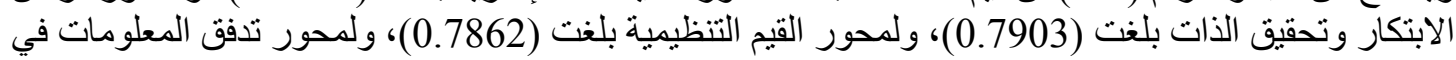

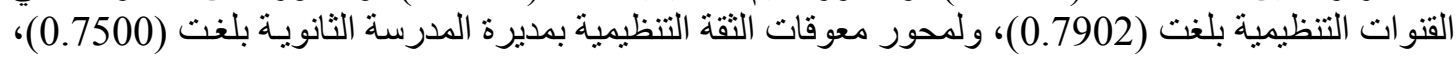

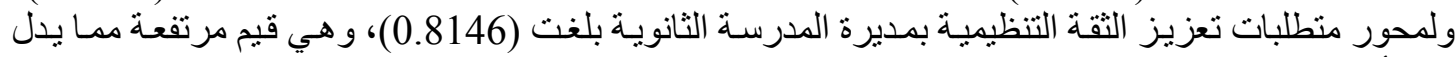

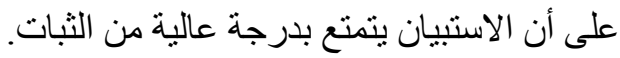

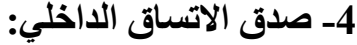




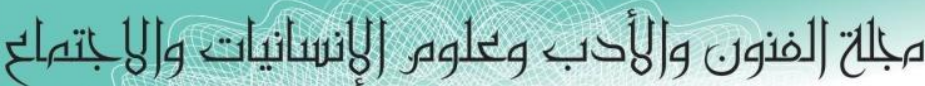

Journal of Arts, Literature, Humanities and Social Sciences

ISSN online: 2414 - 3383

ISSN print: 2616 - 3810

\section{العدد (43) ايلول -سبتمبر 2019}

LALLHSS WWw.jalhss.com

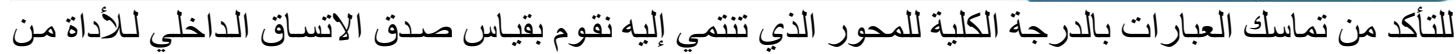

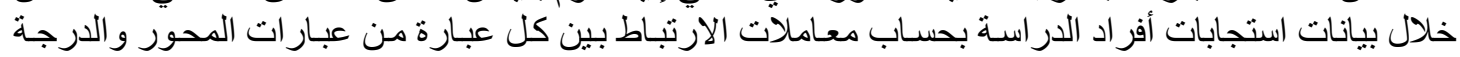

الكلية للمحور الذي تتنمي إلبه باستخدام معامل الارتباط بيرسون "Person Coefficient Correlation"

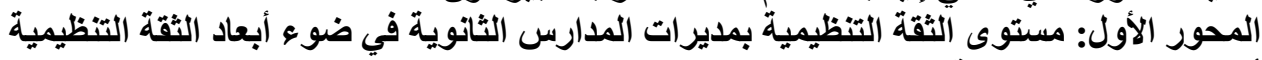

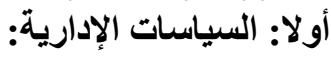
جدول (3-4) معاملات الارتباط لكل عبارة من عبارات المحور بالدرجة الكلية للمحور الذي تنتمي إليه

\begin{tabular}{|c|c|c|}
\hline 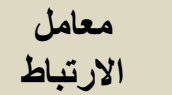 & 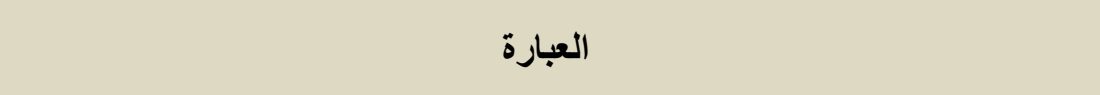 & r \\
\hline$* * 00.742$ & تمنح مديرة المدرسة الثانوية صلاحيات تتناسب مع المسئوليات و المهام المنوطة بها & 1 \\
\hline$* * 0.841$ & التثارك مديرة المدرسة الثانوية في صنع بعض الترارية ات ات المهمة لسير العملية & 2 \\
\hline$* * 0.606$ & يوجد نظام حفز عادل مرتبط بالأداء و الخبرات و القدر ات و الجهود التي تبذلها مديرة & 3 \\
\hline$* * 0.601$ & توفر مديرة المدرسة متطلبات المدرسة من الميز انية المخصصة لمدرستها دون & 4 \\
\hline$* * 0.710$ & يتم تفويض مديرة المدرسة ببعض الصلاحيات في حال غياب المشرفة التربوية. & 5 \\
\hline$* * 0.643$ & التنظرية مديرة المدرسة بأنها عضو فعال يعتمد عليه في تحقيق بعض الأهداف & 6 \\
\hline$* * 0.617$ & تلحدد مديرة المدرسة احتياجات المدرسة المادية والبشرية وتتخذ التدابير والإجر اءات & 7 \\
\hline
\end{tabular}

يتضح من الجدول رقم (3-4) أن جميع معاملات الارتباط دالة إحصـائياً عند مستوى (0.01) ممـا يشير إلى

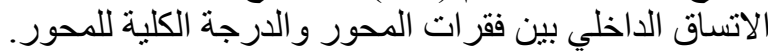
تانيا: فرص الابتكار وتحقيق الأتات:

جدول (3-5) معاملات الارتباط لكل عبارة من عبارات المحور بالدرجة الكلية للمحور الذي تنتمي إليه

\begin{tabular}{|c|c|c|}
\hline 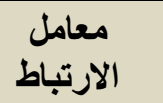 & العبارة & p \\
\hline$* * 0.738$ & تشعر مديرة المدرسة بالاستقلالية بمدرستها و أنها هي المسئولة الأولى عنها. & 1 \\
\hline$* * 0.701$ & تطر ح مديرة المدرسة أفكار ها بطلاقة وبحرية تامة في لقاءات واجتماعات العمل.. & 2 \\
\hline$* * 0.687$ & 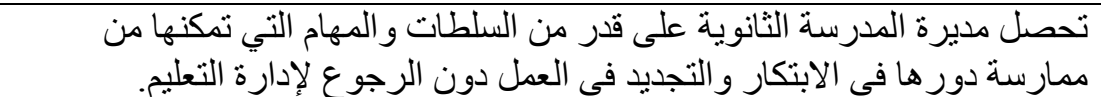 & 3 \\
\hline$* * 0.651$ & 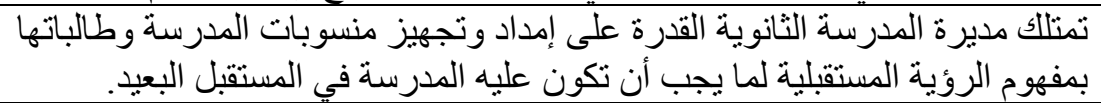 & 4 \\
\hline$* * 0.758$ & تمنح مديرة المدرسة المجتهدة امتياز ات تعطيها إحساسا متو اصلا بر غبة في الانجاز. & 5 \\
\hline$* * 0.681$ & تمتللك مديرة المدرسة الثانوية الجر أة على تفويض الصـلاحيات و المهام في العمل. & 6 \\
\hline
\end{tabular}

0.01 (*) 0.

يتضـح من الجدول رقم (3-5) أن جميع معاملات الارتباط دالة إحصـائياً عند مستوى (0.01) ممـا يشير إلى لـى

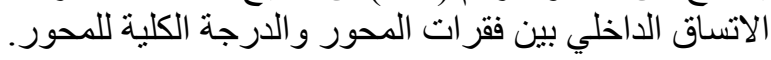




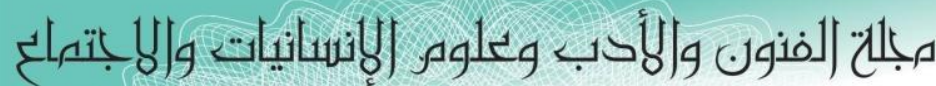
Journal of Arts, Literature, Humanities and Social Sciences

ISSN online: 2414 - 3383

ISSN print: 2616 - 3810

\section{العدد (43) ايلول - سبتهبر 2019}

LALHSS

www.jalhss.com

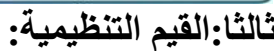

جدول (3-6) معاملات الارتباط لكل عبارة من عبارات المحور بالدرجة الكلية للمحور الذي تنتمي إليه

\begin{tabular}{|c|c|c|}
\hline 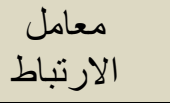 & 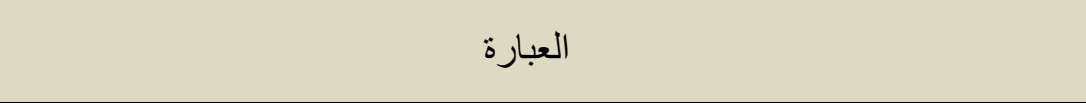 & r \\
\hline$* * 0.663$ & يتم تطبيق مبدأ تكافؤ الفرص على جميع مدير ات المدارس الثانوية بدرجة منماثلة. & 1 \\
\hline$* * 0.813$ & تستشعر مديرة المدرسة الثانوية روح العدالة والإنصاف في التعامل معها. & 2 \\
\hline$* * 0.691$ & لتمكينهن من الإشراف تحقيق التربوي معاف المرجوة المدرسة في تتمية قدر ات منسوبات المدرسة & 3 \\
\hline$* * 0.783$ & تشعر مديرة المدرسة أن هناك من بيثق بقرتها على إنجاز العمل دون رقابة. & 4 \\
\hline$* * 0.733$ & يزداد لدى مديرة المدرسة الشعور بالأمن الوظيفي الناتج عن اشباع حاجاتها النفسية & 5 \\
\hline
\end{tabular}

يتضح من الجدول رقم (3-6) أن جميع معاملات الارتباط دالة إحصـائياً عند مستوى (0.01) ممـا يثبر إلى

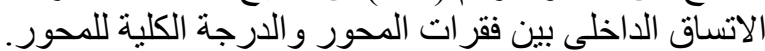

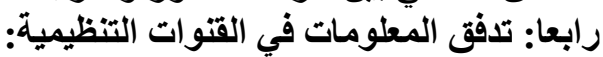

جدول (3-7) معاملات الارتباط لكل عبارة من عبارات المحور بالدرجة الكلية للمحور الذي تنتمي إليه

\begin{tabular}{|c|c|c|}
\hline 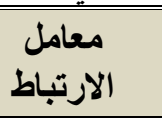 & 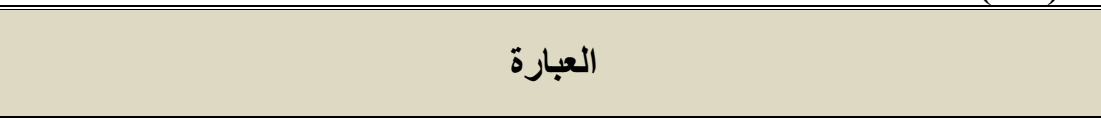 & p \\
\hline$* * 0.704$ & التنظيمية. & 1 \\
\hline$* * 0.718$ & المناسب مديرة المدرسة الثانوية بالمعلومات الثناملة و الدقيقة التي تحتاجها بالوقت & 2 \\
\hline$* * 0.363$ & 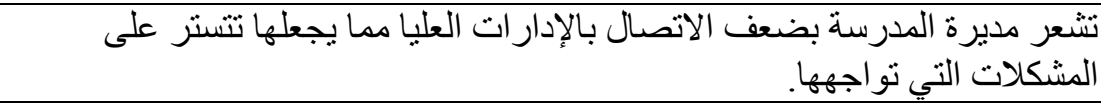 & 3 \\
\hline$* * 0.753$ & ونظور ها. للمعومات التي تقدمها مديرة المدرسة على أنها حيوية ومهمة في عمل المنظمة & 4 \\
\hline$* * 0.810$ & يتم التعامل مع القضايا المختلفة و المتعلقة بمديرة المدرسة الثنانوية بشفافية ووضوح. & 5 \\
\hline$* * 0.819$ & التترفق المعلومات دون في جميع الاتجاهات بشكل يساعد مديرة المدرسة الثانوية في اتخاذ & 6 \\
\hline
\end{tabular}

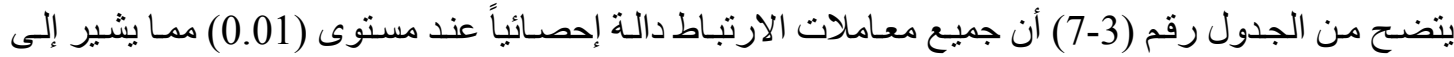
الاتساق الداخلي بين فقر ات المحور وان جالدرجة الكلية للمحور.

المحور الثاني: معوقات الثقة التظظيمية بمديرة المدرسة الثانوية

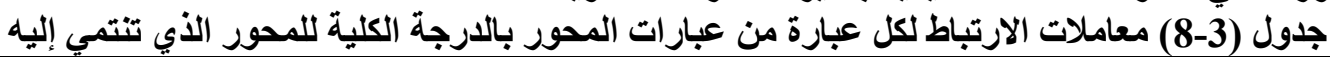

\begin{tabular}{|c|c|c|}
\hline الارتباط & العبار & b \\
\hline$* * 0.331$ & مركزية اتخاذ القرار ات التعليمية & 1 \\
\hline$* 0.279$ & ضعف وضوح السياسات الإدارية العليا. & 2 \\
\hline
\end{tabular}




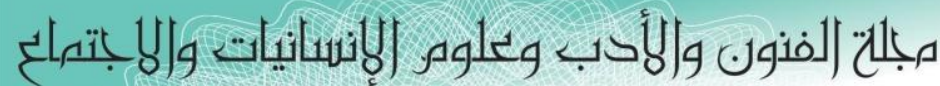

Journal of Arts, Literature, Humanities and Social Sciences

ISSN online: 2414 - 3383

ISSN print: $\mathbf{2 6 1 6}$ - $\mathbf{3 8 1 0}$

\section{العدد (43) ايلول - سبتهبر 2019}

\begin{tabular}{|c|c|c|}
\hline الارتباط معامل & العبارة & م \\
\hline$* * 0.473$ & غياب المعايير في تقويم الأداء الإداري لمدير ات المدارس الثانوية. & 3 \\
\hline$* * 0.493$ & قلة و عي بعض مدير ات المدارس الثانوية بالأنظمة و التعليمات المتعلقة بالمهنة. & 4 \\
\hline$* * 0.552$ & مستوى المؤهل التعليمي الذي تحمله مديرة المدرسة. & 5 \\
\hline$* * 0.671$ & ضعف المهار ات القيادية لدى بعض مدير ات المدارس الثانوية. & 6 \\
\hline$* * 0.627$ & ضعف معايير اختيار مديرة المدرسة الثانوية. & 7 \\
\hline$* * 0.771$ & قلة قدرة المديرة على تحليل العمل المطلوب إنجازه. & 8 \\
\hline$* * 0.755$ & تدني مهارة المديرة في توظيف المعلومات التي تساعد على صنع القرار المدرسي & 9 \\
\hline$* * 0.477$ & قلة عدد سنوات الخبرة لمديرة المدرسة الثانوية في مجال العمل الإداري & 10 \\
\hline$* * 0.418$ & تداخل مهام وصلاحيات مديرة المدرسة الثانوية و المشرفة التربوية & 11 \\
\hline$* * 0.522$ & ضعف المهار ات الحاسوبية لدى بعض مديرات المدارس الثانوية & 12 \\
\hline
\end{tabular}

يتضح من الجدول رقم (3-8) أن جميع معاملات الارتباط دالة إحصائياً عند مستوى (0.01 و و 0.05 (205) ممـا يشير

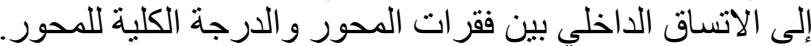

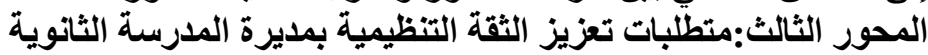

جدول (3-9) معاملات الارتباط لكل عبارة من عبارات المحور بالارجة الكلية للمحور الأي تثتمي إليه

\begin{tabular}{|c|c|c|}
\hline 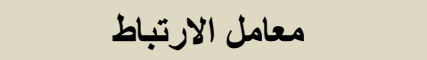 & 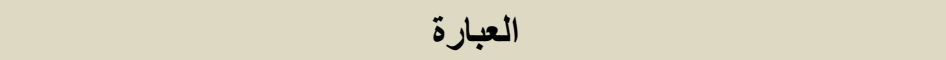 & م \\
\hline لا يمكن حسابها وذللك لأن جميع & تطوير اللوائح والأنظمة لتفعيل دور مديرة المدرسة الثانوية في عملية & 1 \\
\hline$* * 0.463$ & الاتجاه نحو اللامركزية في إدارات التربية و التعليم & 2 \\
\hline$* * 0.516$ & و توضيح رؤية ورسالة المدرسة و أهدافها للهيئة الإدارية التعليمية & 3 \\
\hline$* * 0.531$ & منسوبات المدرسة التوصيف الوظيفي الدقيق تتظيق لمهام ومسئوليات المديرة وجميع & 4 \\
\hline$* * 0.588$ & تخطلبات المدرسة ميز انية مناسبة لمديرة المدرسة الثانوية تتولى بهام تلبية & 5 \\
\hline$* * 0.588$ & تنمية المهار ات القيادية لدى مديرة المدرسة. & 6 \\
\hline$* * 0.733$ & تحديد آلية واضحة لعملية اختيار مدير ات المدارس الثانوية. & 7 \\
\hline$* * 0.503$ & في عملها الإشر مديرة المدرسة الثانوية بالأساليب الإشر افية المختلفة للاستفادة منها & 8 \\
\hline$* * 0.418$ & عمل دور ات تدريبية لمديرات المدارس تتمي مهار ات الحوار لديهن. & 9 \\
\hline$* * 0.345$ & الثانوية. دمل دررات تدريبية لتنمية المهار ات الحاسوبية لدى مديرة المدرسة & 10 \\
\hline$* * 0.419$ & بكافة أعمالها دون المدرسة الثانوية المزيد من الصولاحيات التي تمكنها من القيام & 11 \\
\hline
\end{tabular}


مجلحت (لفنون والأدب وعلوهر الإنسانيات والبغتهماع

Journal of Arts, Literature, Humanities and Social Sciences

ISSN online: 2414 - 3383

ISSN print: 2616 - 3810

\section{أيلول - سبتمبر 2019}

العدد (43)

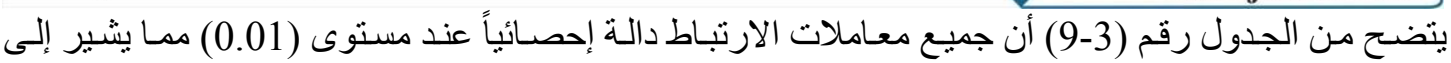
الاتساق الداخلي بين فقرات الدحور والدرجة الكلية للمحور.

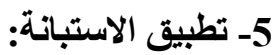

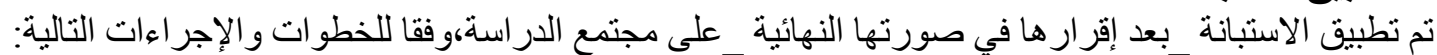

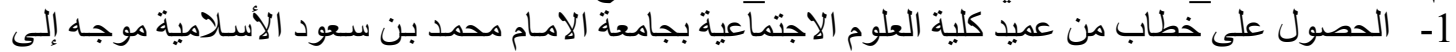

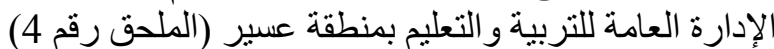

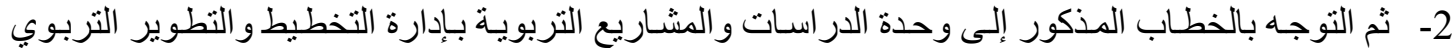

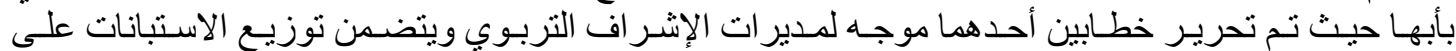

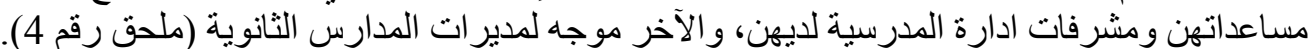

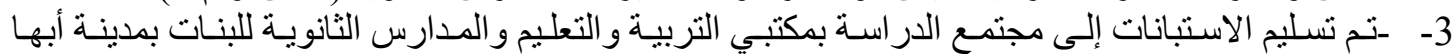

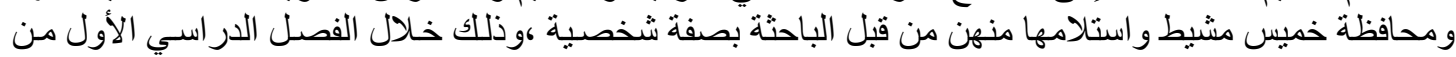

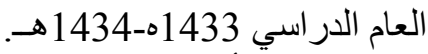
4- ت تم توزيع أداة الدراسة على (64) مفردة وهن إجمالي مجتمع الدراسة ،وقد تم استعادة (64) استبانة جميعها صالحة. و الجدول رقم (3-10) يوضح الاستبانات الموز عة والدستعادة و المستوفاة ونسبة المجيبات.

جدول رقم (10-3)الاستبانات الموزعة و المستعادة والمستوفاة ونسبة المجيبات

\begin{tabular}{|c|c|c|c|c|}
\hline نسبة المجيبات & عدلد الاستباناتات & عدد الاستباناتات & الاستبانات & الفئة \\
\hline$\% 3,1$ & 2 & 2 & 2 & مديرة إنشر اف \\
\hline$\% 7,8$ & 5 & 5 & 5 & مساعدة مديرة إثر اف \\
\hline$\% 28,1$ & 18 & 18 & 18 & مشرفة إدارة مدرسية \\
\hline$\% 60,9$ & 39 & 39 & 39 & مديرة مدرسة ثانوية \\
\hline$\% 100$ & 64 & 64 & 64 & المجموع ل \\
\hline
\end{tabular}

وقد تم حساب المدى لمقياس الاستبانة على النحو التالي: $2=1-3$

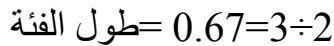

وبذلك يكون لدينا ثلاث فئات على النحو النالي:

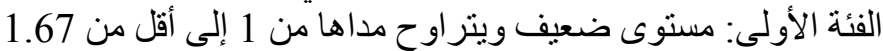

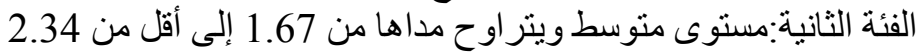
الفئة الثالثة:مستوى عالي ويتراو حتد مداها من 2.34 إلى أقلى من 3

4-3 - 2 - 2 أسلوب تحليل البياتات

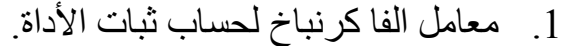
2.

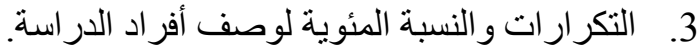

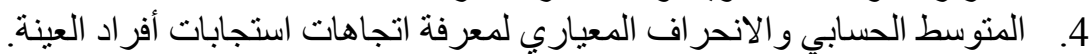
5. 6. أختبار نحليل التباين لمعرفة الفروق الإحصائية. 7. 1 اختبار (LSD) لمعرف مصدر الفروق الإحصائية. 


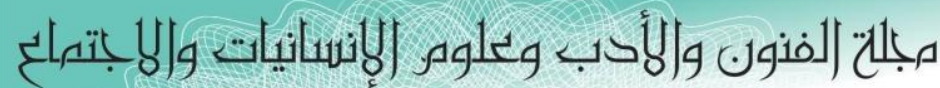

Journal of Arts, Literature, Humanities and Social Sciences

ISSN online: 2414 - 3383

ISSN print: 2616 - 3810

\section{العدد (43) ايلول - سبتمبر 2019}

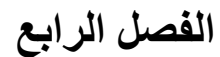 \\ تحليل المطلومات وتفسبر ها}

مقامة:

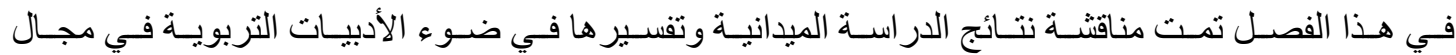

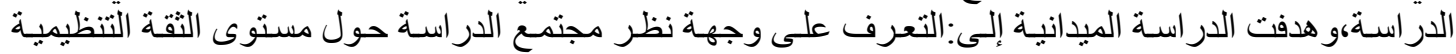

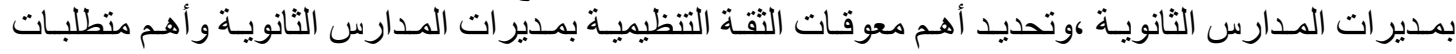
تعزيز ها. وفيما يلي عرضل لنتائج الدراسة وفقا لأسئلة الدر اسة ،حيث يتم طرح السؤ ال ثم الإجابة عليه مبانشرة من الجداول

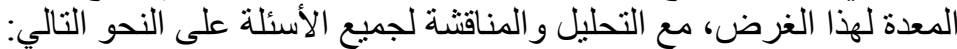

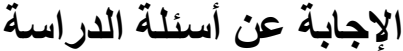

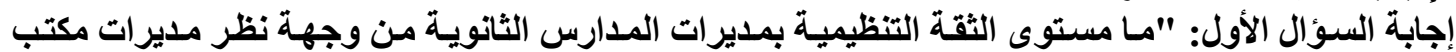

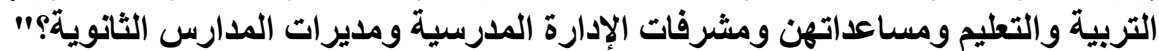

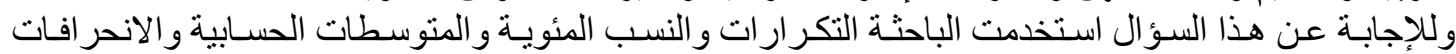
المعبارية.

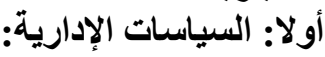

جدول (1-4) يبين رأي مجتمع الاراسة حول السياسات الإدارية

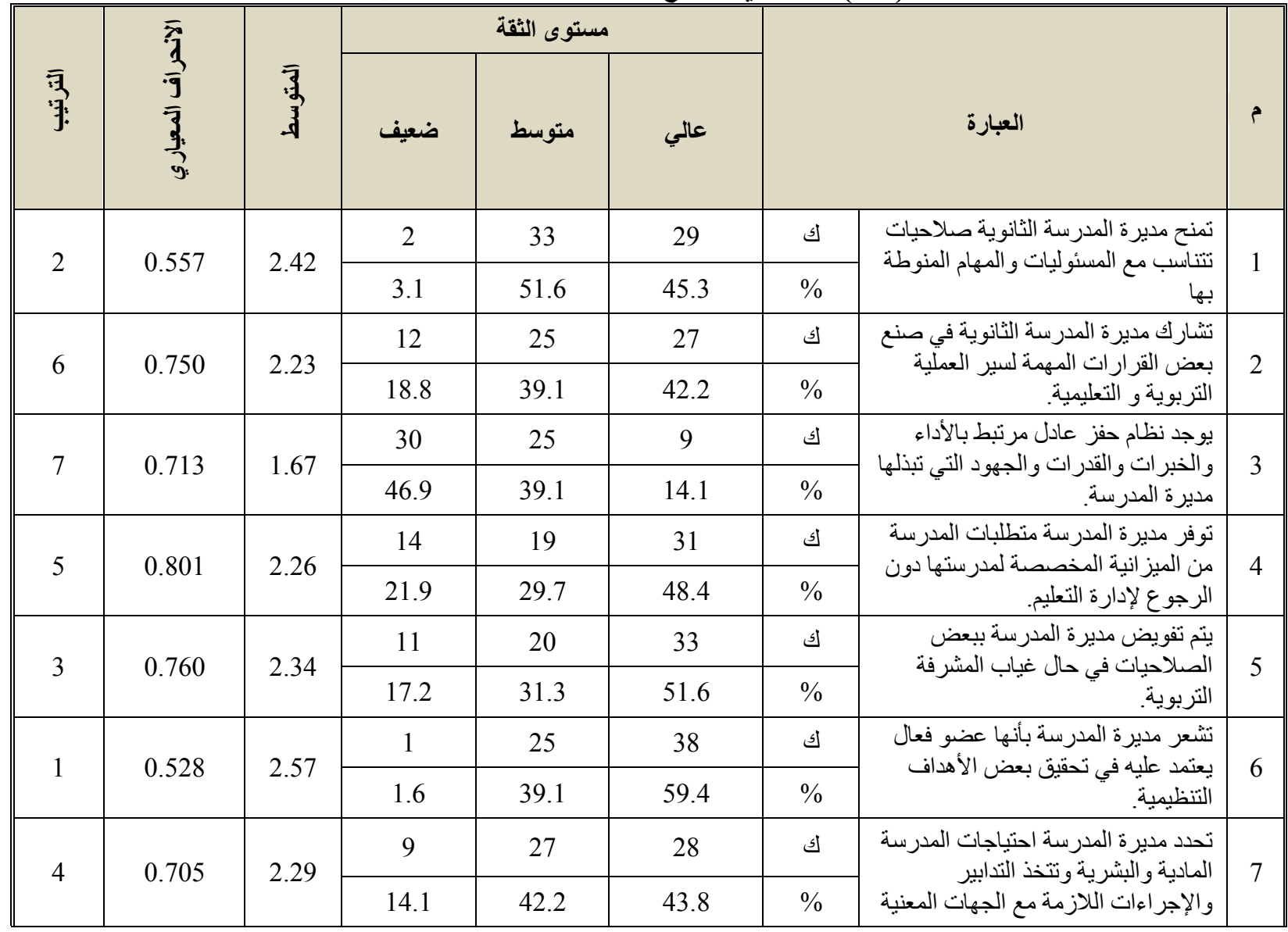




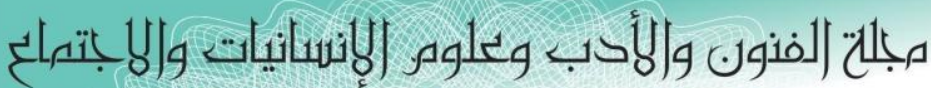

Journal of Arts, Literature, Humanities and Social Sciences

ISSN online: 2414 - 3383

ISSN print: 2616 - 3810

العدد (43) ايلول - سبتهبر 2019

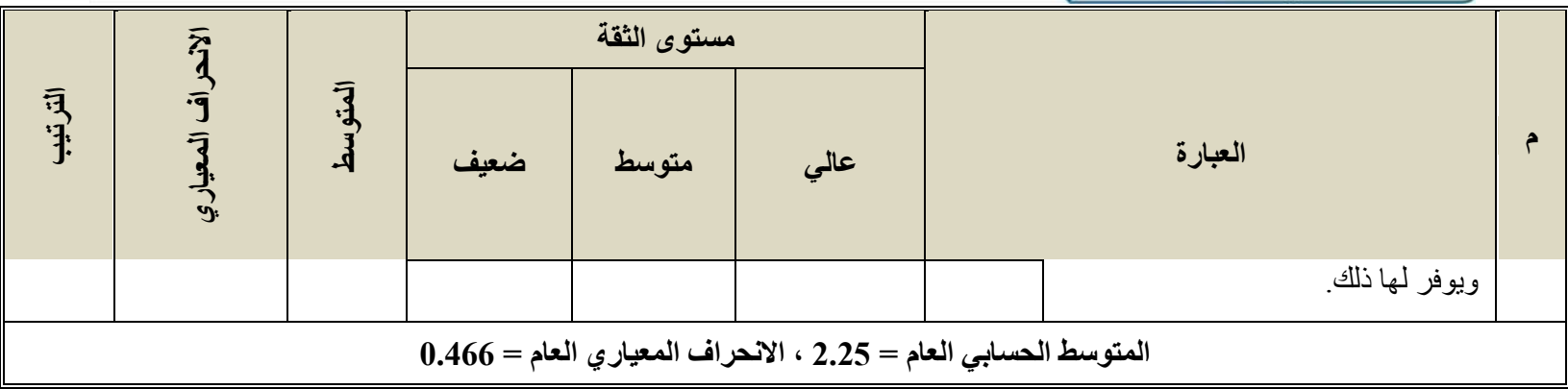

يتضح من الجدول (4-1) أن المتوسط الحسابي العام لبعد السياسات الإدارية بلغ (2,25) و هو بذللك ينتمي لفئة

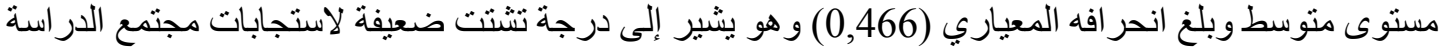

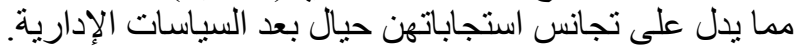

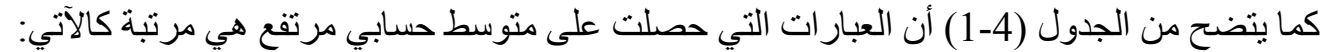

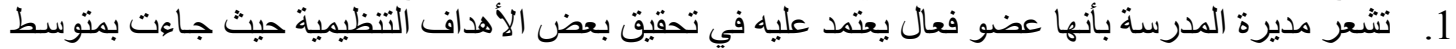

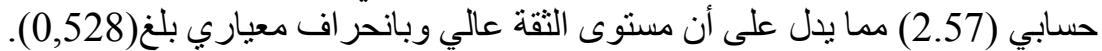

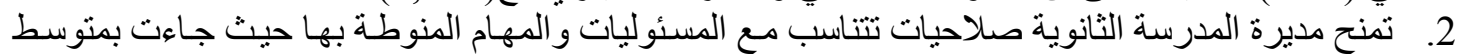

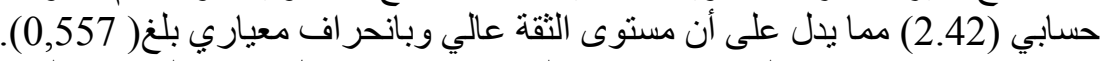

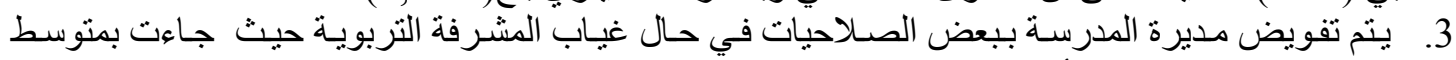

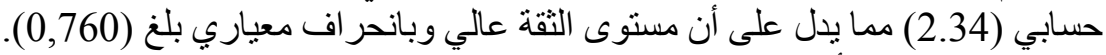

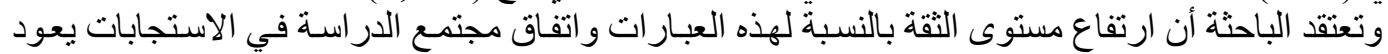

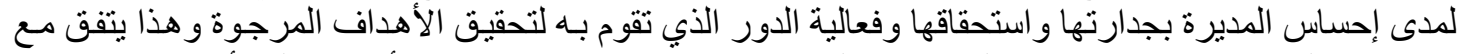

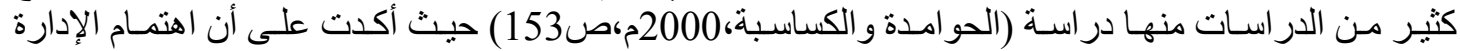

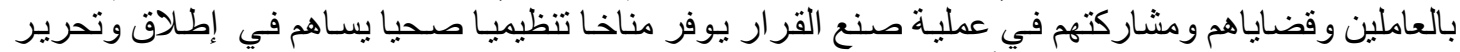

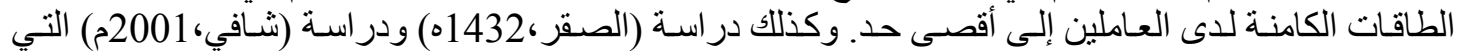
اوصت بمنح مديرة المدرسة مزيدا من الصلاحيات والاستقلالية لمديري ومدير الكات المات المدارس.

و أيضا يتضح من الجدول (4-1) أن العبارات التي حصلت على منوسط حسابي منخفض هي كالآتي:

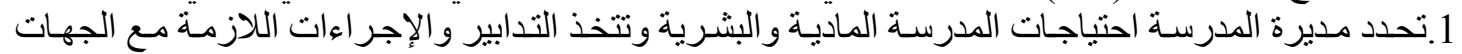

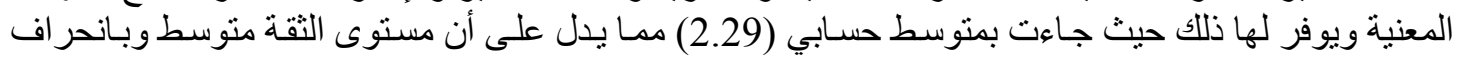
معياري بلغ (0.705).

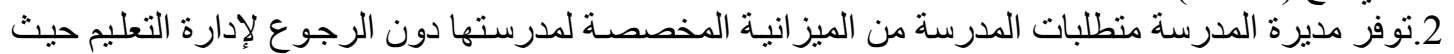

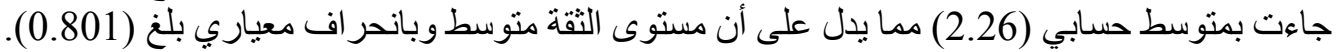

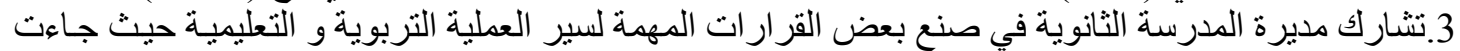

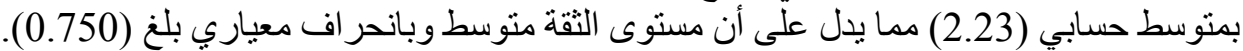

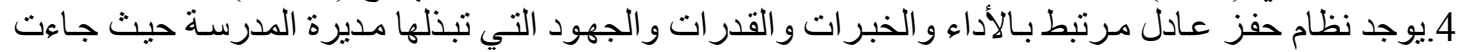

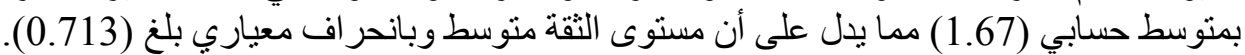

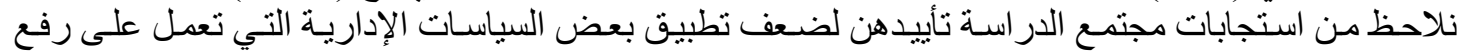

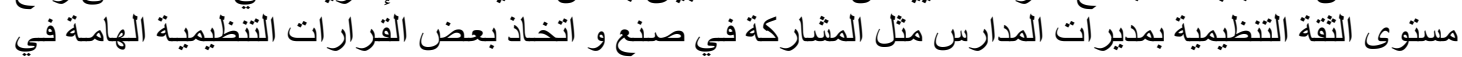

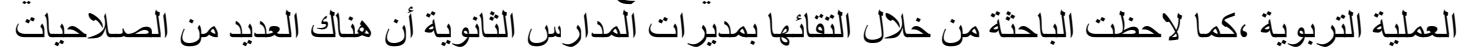

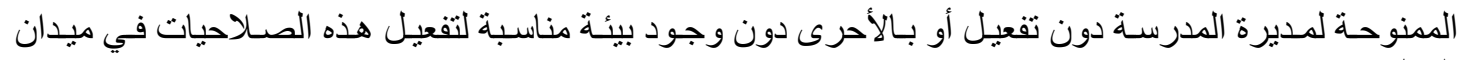




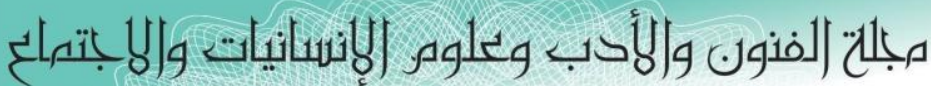

Journal of Arts, Literature, Humanities and Social Sciences

ISSN online: 2414 - 3383

ISSN print: 2616 - 3810

\section{العدد (43) ايلول - سبتهبر 2019}

HALHSS

www.jalhss.com

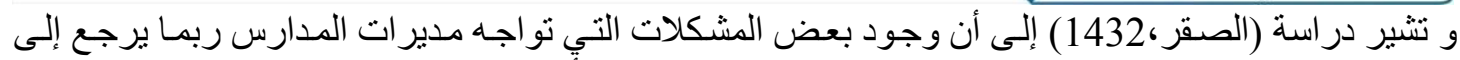

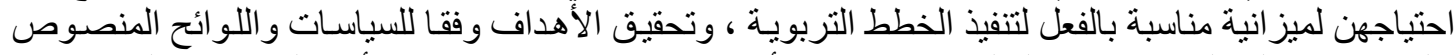

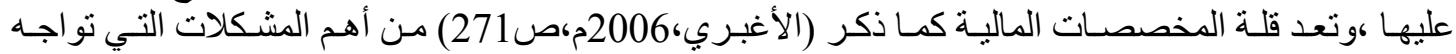
التخطيط التربوي. ثانيا: فرص الابتكار وتحقيق الذات: جدول (4-2) يبين رأي مجتمع الدراسة حول فرص الابتكار وتحقيق الذات

\begin{tabular}{|c|c|c|c|c|c|c|c|c|}
\hline \multirow{2}{*}{ 羿 } & \multirow{2}{*}{ 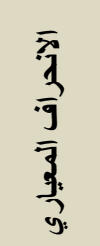 } & \multirow{2}{*}{ 裹 } & \multicolumn{3}{|c|}{ مستوى الثقة } & \multirow{2}{*}{\multicolumn{2}{|c|}{ العبارة }} & \multirow[b]{2}{*}{ e } \\
\hline & & & ضعيف & متوسط & عالى & & & \\
\hline \multirow{2}{*}{2} & \multirow{2}{*}{0.590} & \multirow{2}{*}{2.50} & 3 & 26 & 35 & ك & \multirow{2}{*}{ تمدرستها و أنها هي المسئولة الأولىلى } & \multirow{2}{*}{1} \\
\hline & & & 4.7 & 40.6 & 54.7 & $\%$ & & \\
\hline \multirow{2}{*}{3} & \multirow{2}{*}{0.663} & \multirow{2}{*}{2.43} & 6 & 24 & 34 & ك & \multirow{2}{*}{ تطحرح مديرة المدرسة أفكار ها بطاتلاقة واجمات } & \multirow{2}{*}{2} \\
\hline & & & 9.4 & 37.5 & 53.1 & $\%$ & & \\
\hline \multirow{2}{*}{5} & \multirow{2}{*}{0.709} & \multirow{2}{*}{2.14} & 12 & 31 & 21 & s) & \multirow{2}{*}{ 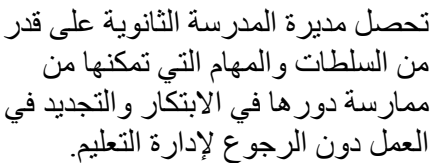 } & \multirow{2}{*}{3} \\
\hline & & & 18.8 & 48.4 & 32.8 & $\%$ & & \\
\hline \multirow{3}{*}{4} & \multirow{3}{*}{0.585} & \multirow{3}{*}{2.42} & 3 & 31 & 30 & (5) & \multirow{3}{*}{ 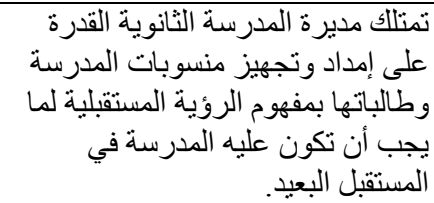 } & \multirow{3}{*}{4} \\
\hline & & & & & & & & \\
\hline & & & 4.7 & 48.4 & 46.9 & $\%$ & & \\
\hline \multirow{2}{*}{6} & \multirow{2}{*}{0.853} & \multirow{2}{*}{2.03} & 22 & 18 & 24 & ك5 & \multirow{2}{*}{ 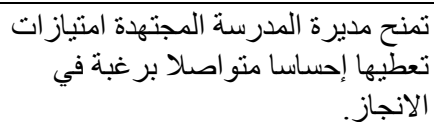 } & \multirow{2}{*}{5} \\
\hline & & & 34.4 & 28.1 & 37.5 & $\%$ & & \\
\hline \multirow{2}{*}{1} & \multirow{2}{*}{0.590} & \multirow{2}{*}{2.51} & 3 & 25 & 36 & ك & \multirow{2}{*}{ 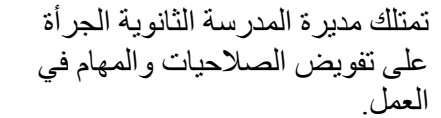 } & \multirow{2}{*}{6} \\
\hline & & & 4.7 & 39.1 & 56.3 & $\%$ & & \\
\hline
\end{tabular}

يتضح من الجدول (4-2) أن المتوسط الحسابي العام لبعد فرص الابتكار وتحقيق الذات بلغ (2,34) وهو بذللك

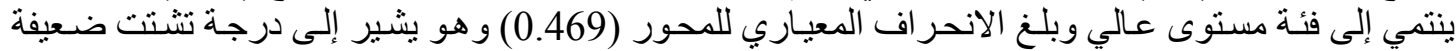

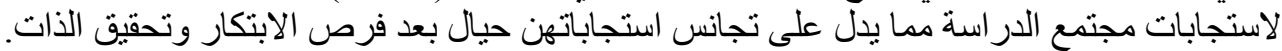

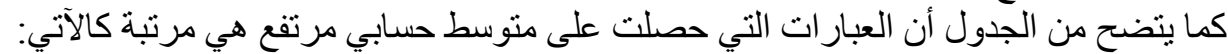

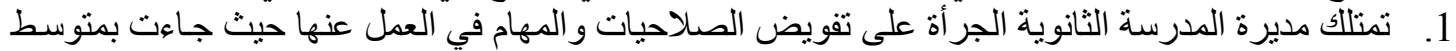

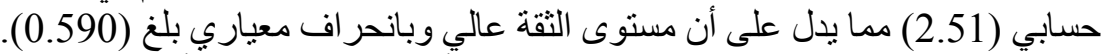

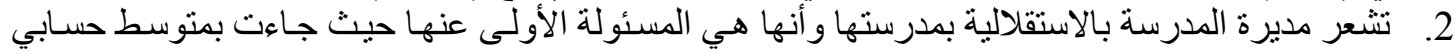
(2.50) مما يدل على أن مستوى الثقة عالي وبانحر اف معياري بلغ (0,590). 


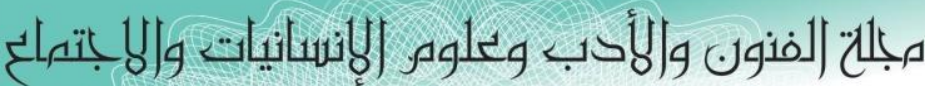

Journal of Arts, Literature, Humanities and Social Sciences

ISSN online: 2414 - 3383

ISSN print: 2616 - 3810

\section{العدد (43) ايلول -سبتمبر 2019}

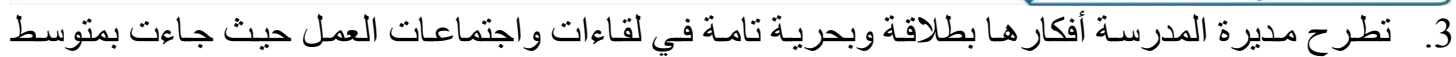

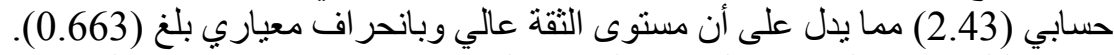

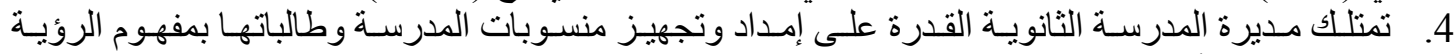
المستقبلية لما يجب أن تكون عليه المدرسة في المستقبل البعيد حيث جاءت بمنتوسط حسابي (2.42) مما يدل على الثى

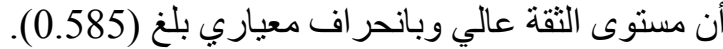

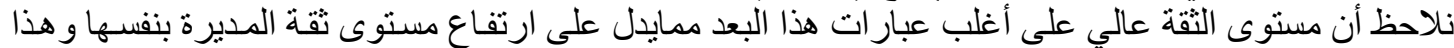

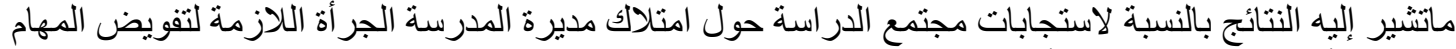

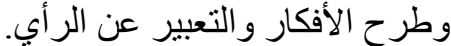

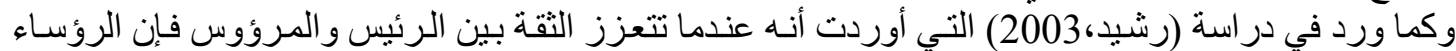

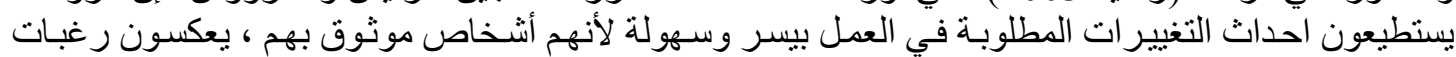

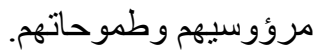
كما يتضح من الجدول السابق (4-2) أن العبار ات التي حصلت على متوسط حسابي منخفض هي:

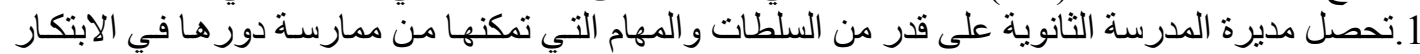

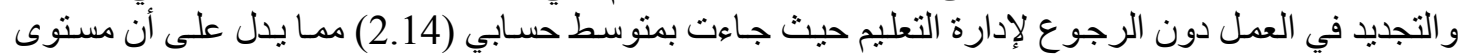

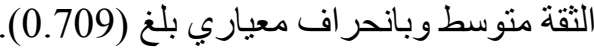

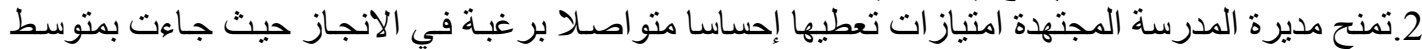

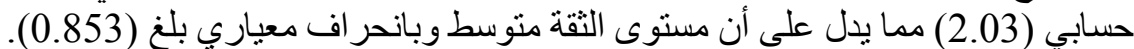

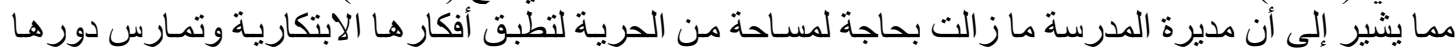
في التجديد كما ينبغي.

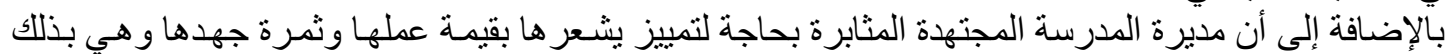

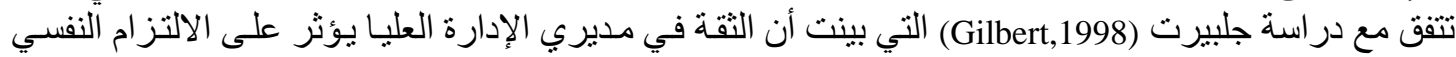

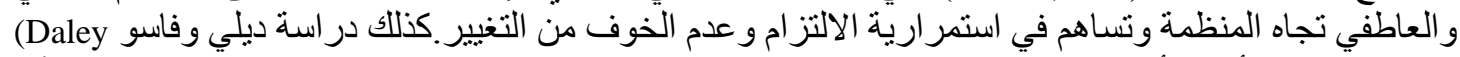
و \& Vasu,1998)

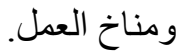

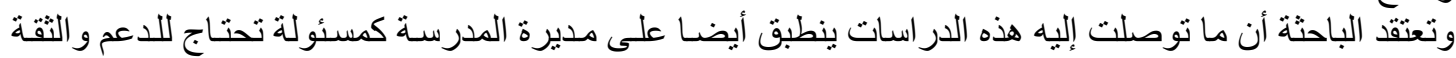

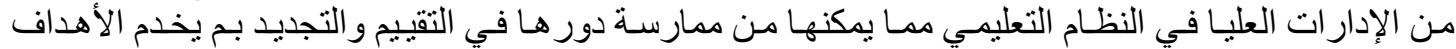

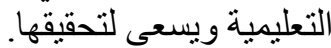

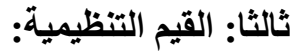

جدول (4-3) يبين رأي مجتمع الدراسة حول القيم التظظيمية

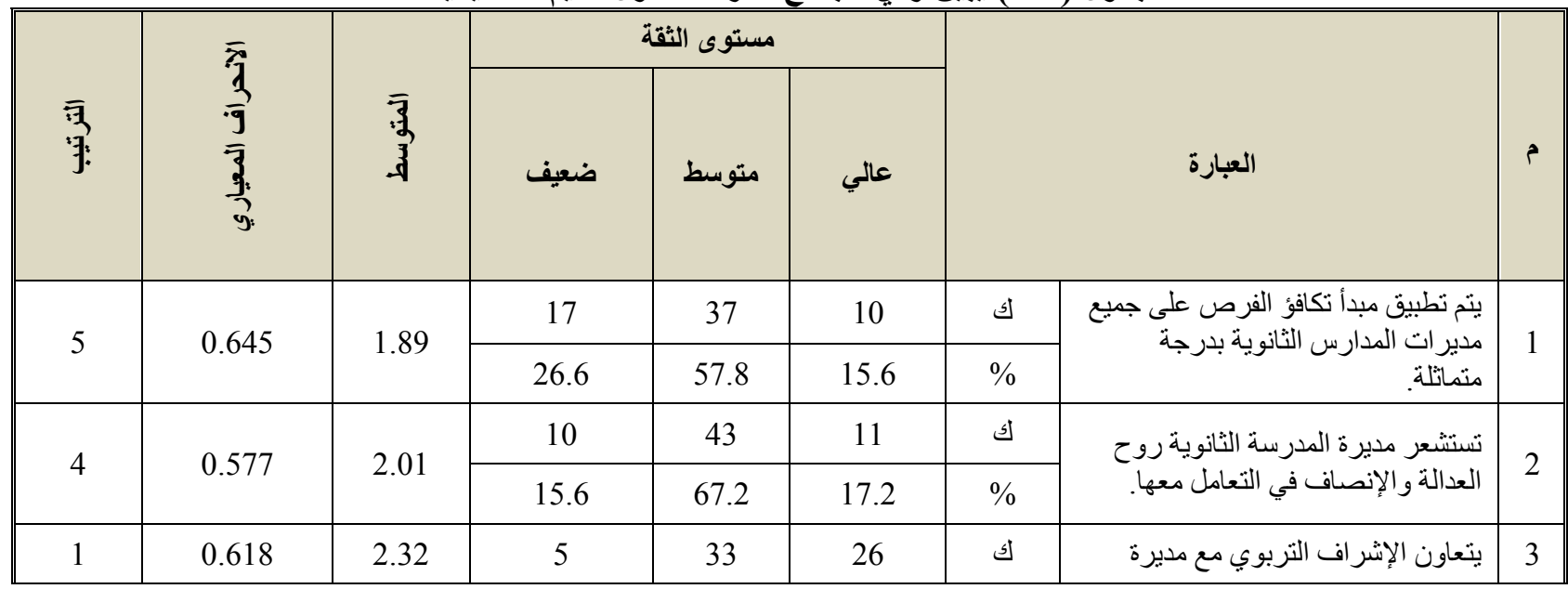




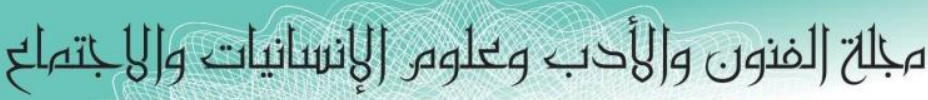
Journal of Arts, Literature, Humanities and Social Sciences

ISSN online: 2414 - 3383

ISSN print: 2616 - 3810

أيلول -سبتمبر 2019
LALHSS

Www.jalhss.com

\begin{tabular}{|c|c|c|c|c|c|c|c|c|}
\hline \multirow{3}{*}{ 㝵: } & \multirow{3}{*}{$\begin{array}{l}\bar{y} \\
\frac{\bar{y}}{9} \\
\bar{y} \\
\frac{3}{y}\end{array}$} & \multirow{3}{*}{$\overline{3}$} & \multicolumn{3}{|c|}{ مستوى الثقة } & & \multirow[b]{2}{*}{ العبارة } & \multirow{3}{*}{ r } \\
\hline & & & ضعيف & متوسط & عالى & & & \\
\hline & & & 7.8 & 51.6 & 40.6 & $\%$ & المدرسة التمكينهن في تنمية قدر ات منسوبات المدرة & \\
\hline \multirow{2}{*}{2} & \multirow{2}{*}{0.731} & \multirow{2}{*}{2.31} & 10 & 24 & 30 & 5 & \multirow{2}{*}{ تشدرتها مديرة المدرسة أن هنالك دن يثّق } & \multirow{2}{*}{4} \\
\hline & & & 15.6 & 37.5 & 46.9 & $\%$ & & \\
\hline \multirow{2}{*}{3} & \multirow{2}{*}{0.613} & \multirow{2}{*}{2.06} & 10 & 40 & 14 & 5 & \multirow{2}{*}{ 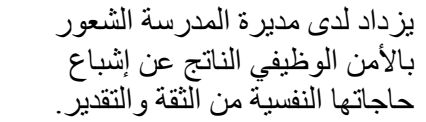 } & \multirow{2}{*}{5} \\
\hline & & & 15.6 & 62.5 & 21.9 & $\%$ & & \\
\hline
\end{tabular}

يتضح من الجدول رقم (4-3) أن المتوسط الحسابي العام لبعد القيم التنظيميـة بلغ (2,12) و هو بذللك ينتمي لفئسة

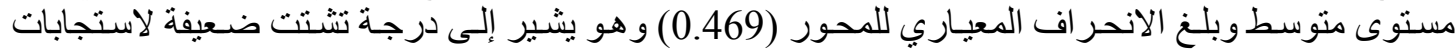

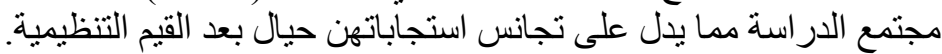

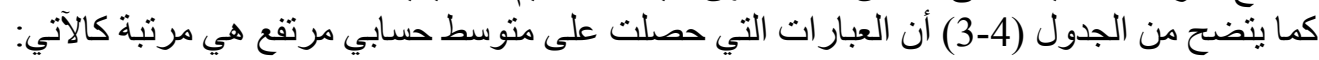

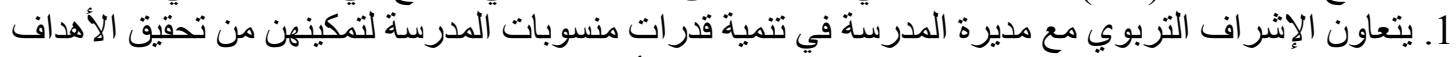

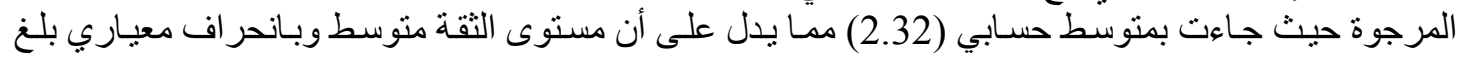

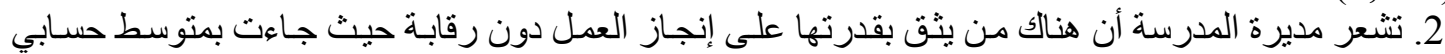

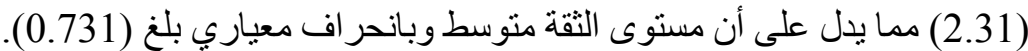

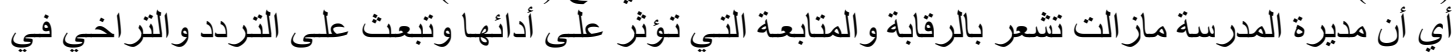

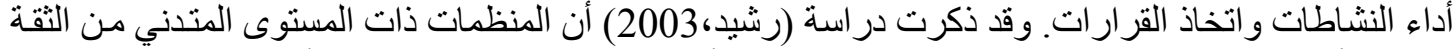

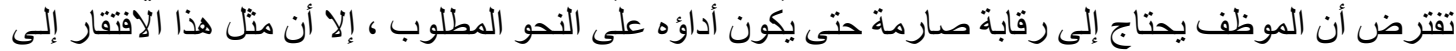

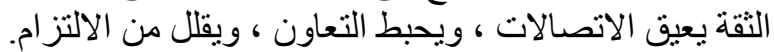
كما يتضح من الجدول السابق (4-3) أن العبارات التيط التي حصلت على الإنى منوسط حسابي منخفض هي كالآتي:

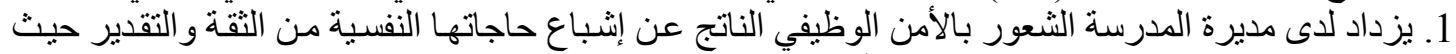

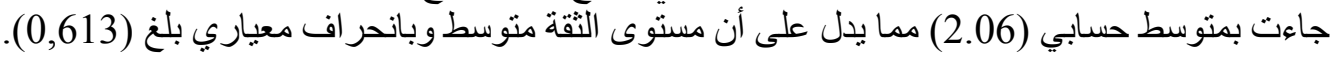

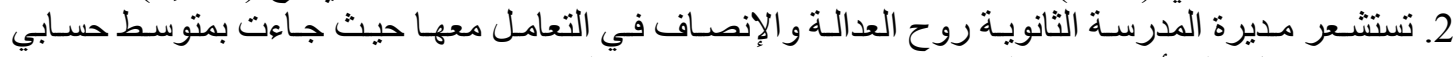

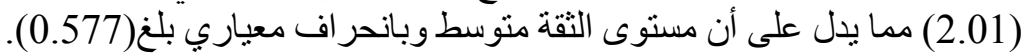

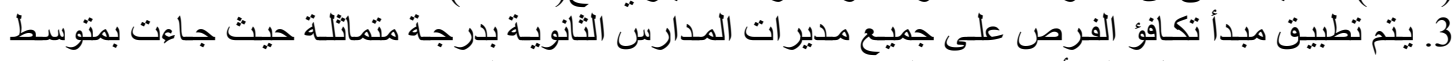

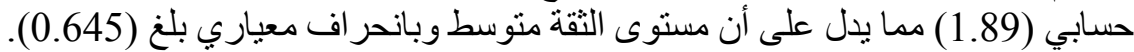

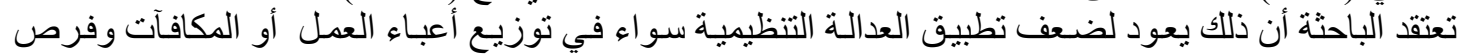

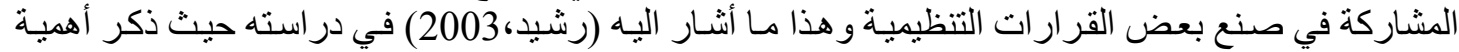

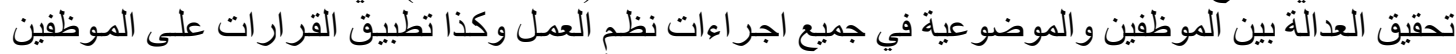

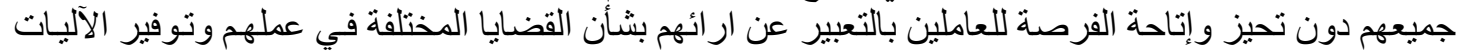

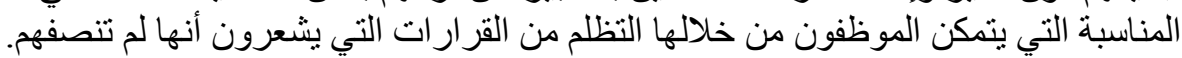

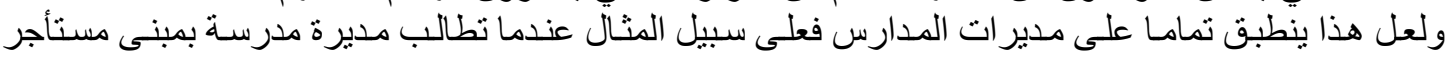

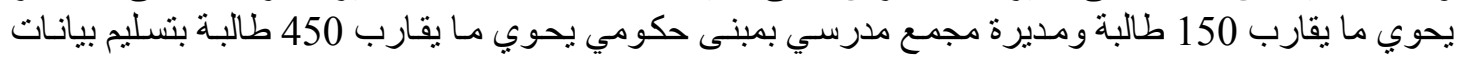




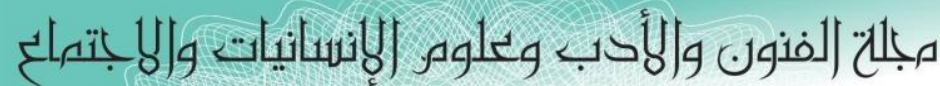

Journal of Arts, Literature, Humanities and Social Sciences

ISSN online: 2414 - 3383

ISSN print: 2616 - 3810

أيلول - سبتمبر الفر 2019

العدد (43)

الطالبات ونتائج الاختبارات بنفس الوقت وتطبق عليهن نفس القر ارات و اللوائح دون مر اعاة الفروق بينهما فإن النان ذلك يسهم في ضعف تقبل مديرة المدرسة لأهداف المنظمة ككل وقيمها.

رابعا:تافق المعلومات في القتوات التنظيمية:

جلول (4-4) يبين رأي مجتمع الداراسة حول تدفق المعلومات في القتوات التنظيمية

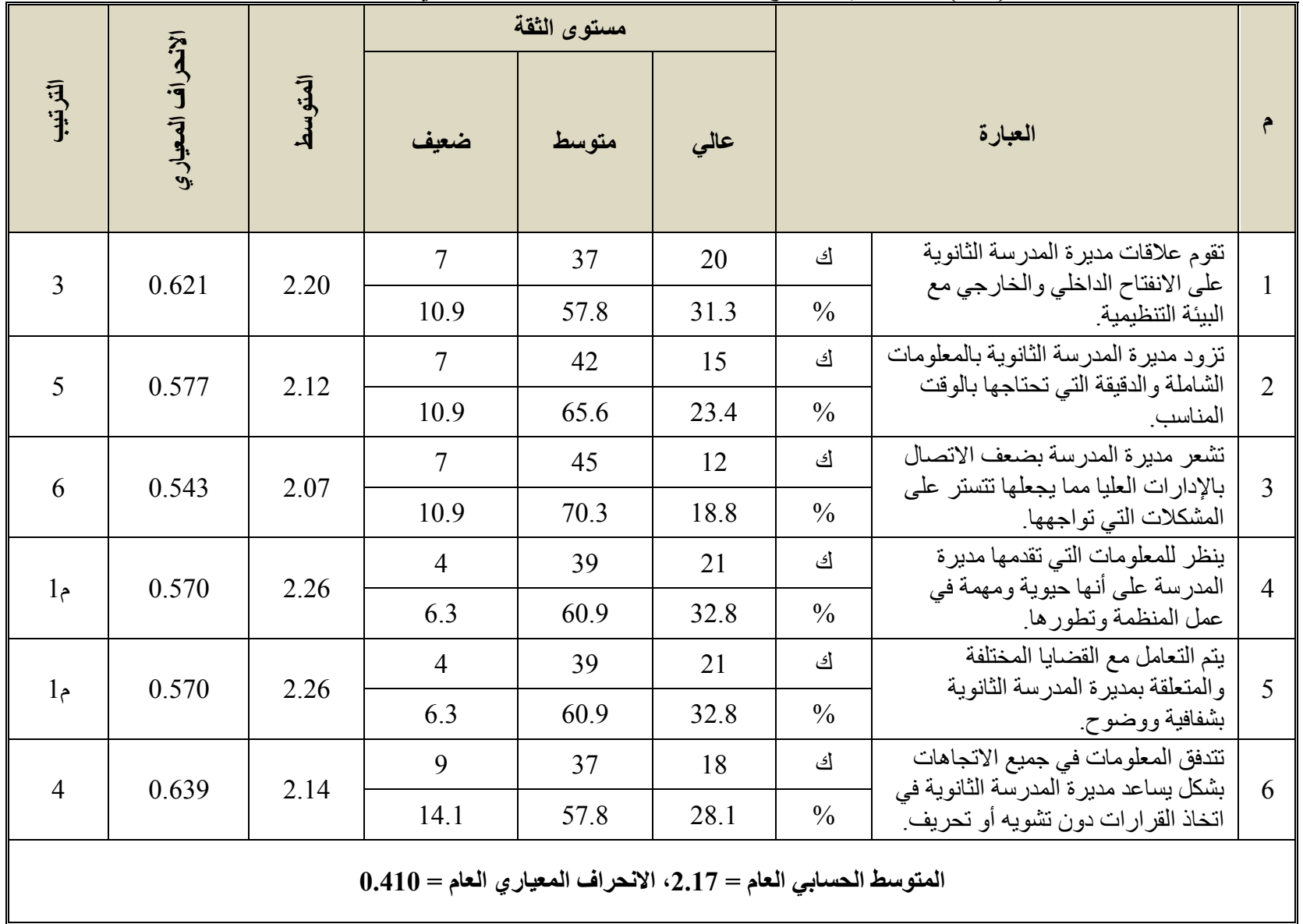

يتضح من الجدول (4-4) أن المتوسط الحسابي العام لبعد تدفق المعلومات في القنو ات التنظيمية بلغ (2.17) و هو

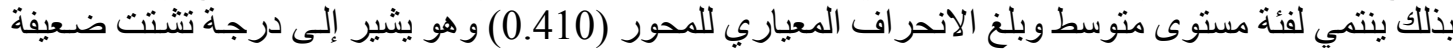

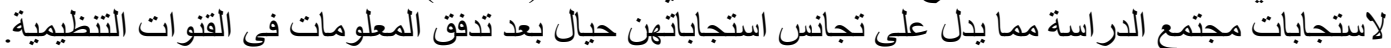

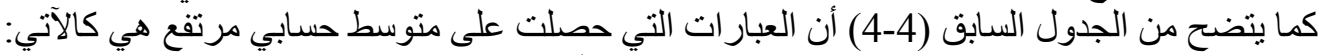

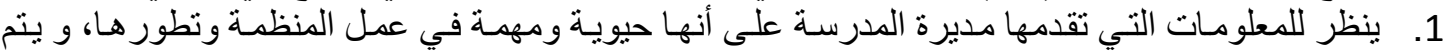

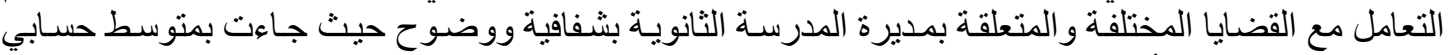

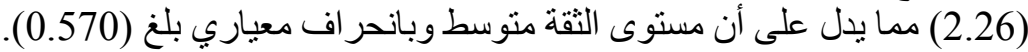

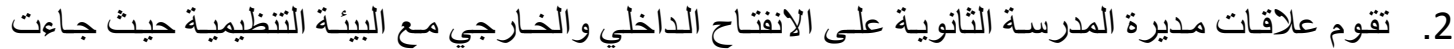
بمنو سط حسابي (2.20) مما يدل على أن مستوى الثقة متوسط وبانحر اف معياري بلغ (0.621). 


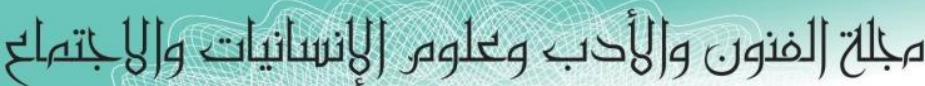

Journal of Arts, Literature, Humanities and Social Sciences

ISSN online: 2414 - 3383

ISSN print: 2616 - 3810

\section{أيلول - لسبتمبر 2019}

العدد (43)

قد بعني ذلك أنه ماز ال هنالك بعض الغموض في التعامل مع القضـايا التي تخص مديرة المدرسـة ممـا بؤثر سـلبا

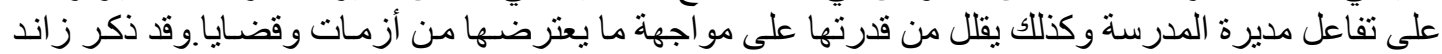
(Zand,1972) تبادل المعلومات والأفكار و المثاعر أو يزيد من الانفتاح ولتأثثير بالآخرين والاعتماد المتبادل وهذه جميعها تزيد

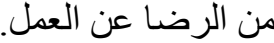
ويتضح أيضا من الجدول (4-4) أن العبار ات التي حصلت على متوسط حسابي منخفض هي كالآتي:

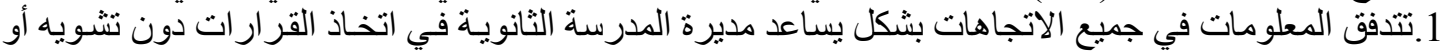

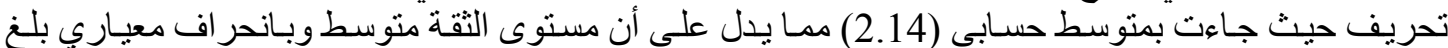

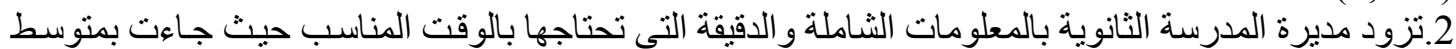

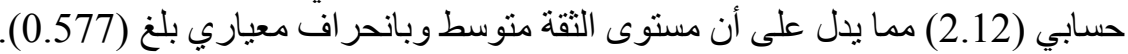

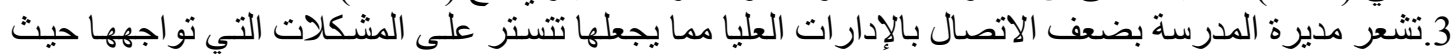

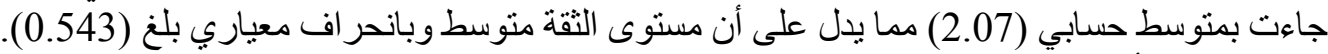
وتعتقد الباحثة أن السبب في ذللك قد يكون ذلك التصور الثـائع الذي يصور مديرة المدرسـة بالثكل المثنالي فلا

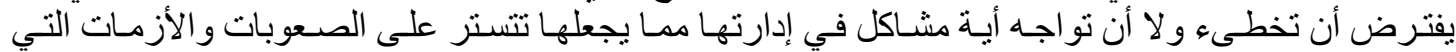

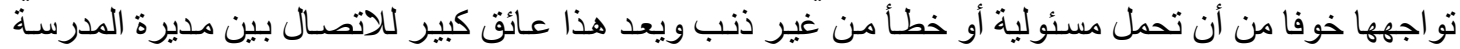

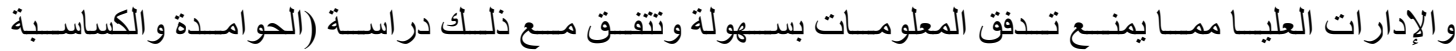

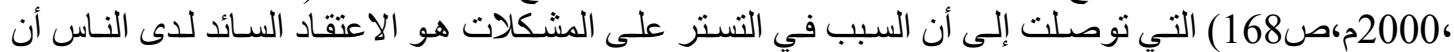

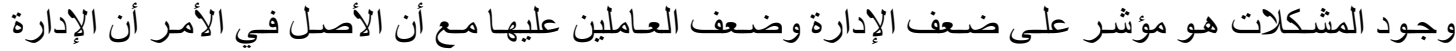

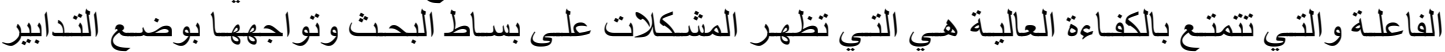

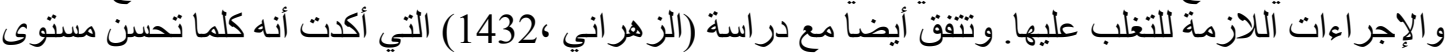

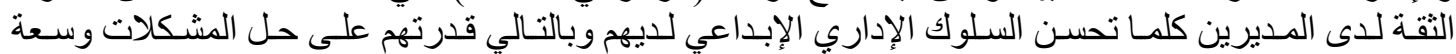

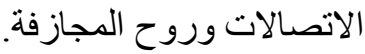
ويشير المتوسط الحسابي لعبارة "تزود مديرة المدرسة الثانوية بالمعلومات الثاملة والدقيقة التي تحتاجها بالوقات

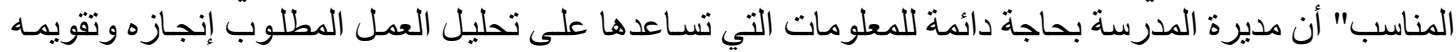

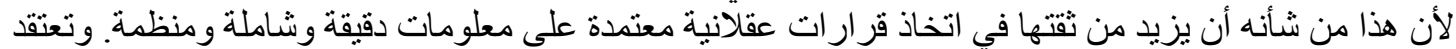
الباحثة أن ضعف حصول المديرة على المعلومات التي تحتاجها بالوقت و القدر المناسبين دليل على وجود خلتل بالتخطيط و عملية ترشيد المعلومات وقد يكون أيضا مؤشر على انخفاض مستوى التقة التنظيمية بمديرة المدرسة.

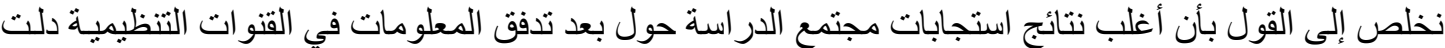

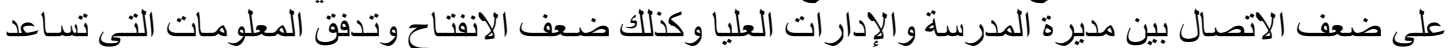

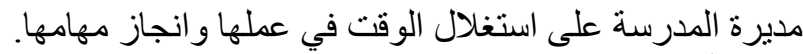

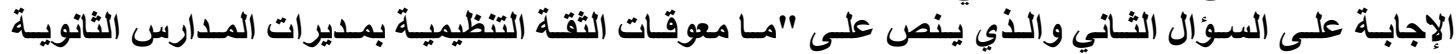

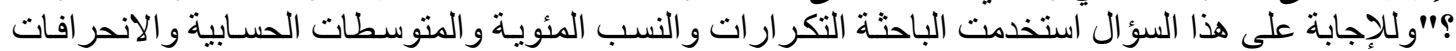

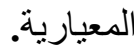

جدول (4-5) يبين رأي مجتمع الدراسة حول معوقات الثقة التنظيمية بمديرات المدارس

\begin{tabular}{|c|c|c|c|c|c|c|c|c|}
\hline \multirow{2}{*}{ 㝵: } & \multirow{2}{*}{$\frac{\bar{y}}{\overline{3}} \bar{y}$} & \multirow{2}{*}{$\begin{array}{l}\overline{3} \\
3 \\
3\end{array}$} & \multicolumn{3}{|c|}{ مستوى المعوق } & & \multirow[b]{2}{*}{ 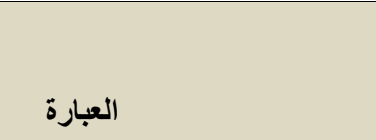 } & \multirow[b]{2}{*}{ p } \\
\hline & & & ضعيف & متوسط & عالي & & & \\
\hline \multirow{2}{*}{1} & \multirow{2}{*}{0.555} & \multirow{2}{*}{2.59} & 2 & 22 & 40 & ك & \multirow{2}{*}{ مركزية اتخاذ القرارات التعليمية. } & \multirow{2}{*}{1} \\
\hline & & & 3.1 & 34.4 & 62.5 & $\%$ & & \\
\hline
\end{tabular}




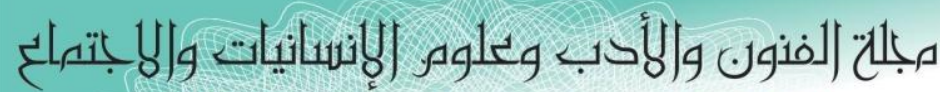
Journal of Arts, Literature, Humanities and Social Sciences

ISSN online: 2414 - 3383

ISSN print: 2616 - 3810

\section{أيلول - سبتمبر 2019}

العدد (43)

\begin{tabular}{|c|c|c|c|c|c|c|c|c|}
\hline \multirow{2}{*}{ 牙: } & \multirow{2}{*}{$\overline{\frac{7}{9}} \bar{y}$} & \multirow{2}{*}{$\overline{3}$} & \multicolumn{3}{|c|}{ مستوى المعوق } & \multirow{2}{*}{\multicolumn{2}{|c|}{ 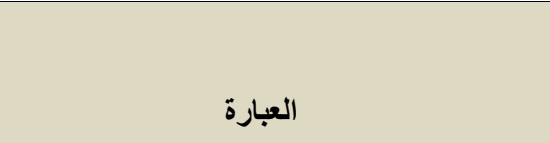 }} & \multirow[b]{2}{*}{ b } \\
\hline & & & ضعيف & متوسط & عالي & & & \\
\hline \multirow{2}{*}{2} & \multirow{2}{*}{0.589} & \multirow{2}{*}{2.45} & 3 & 29 & 32 & ك & \multirow{2}{*}{ ضعف وضوح السياسات الإدارية العليا. } & \multirow{2}{*}{2} \\
\hline & & & 4.7 & 45.3 & 50 & $\%$ & & \\
\hline \multirow{2}{*}{3} & \multirow{2}{*}{0.568} & \multirow{2}{*}{2.20} & 5 & 41 & 18 & 5) & \multirow{2}{*}{ غديراب المعايير في تقويم الأداء الإداري } & \multirow{2}{*}{3} \\
\hline & & & 7.8 & 64.1 & 28.1 & $\%$ & & \\
\hline \multirow{2}{*}{6} & \multirow{2}{*}{0.447} & \multirow{2}{*}{2.07} & 4 & 51 & 9 & 5 & \multirow{2}{*}{ 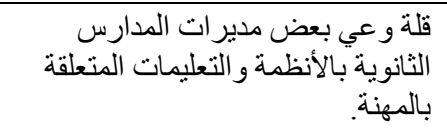 } & \multirow{2}{*}{4} \\
\hline & & & 6.3 & 79.7 & 14.1 & $\%$ & & \\
\hline \multirow{2}{*}{12} & \multirow{2}{*}{0.771} & \multirow{2}{*}{1.76} & 28 & 23 & 13 & 5 & \multirow{2}{*}{ مديرة المدرسوة المؤل التعليمي الذي تحمله } & \multirow{2}{*}{5} \\
\hline & & & 43.8 & 35.9 & 20.3 & $\%$ & & \\
\hline \multirow{2}{*}{5} & \multirow{2}{*}{0.587} & \multirow{2}{*}{2.14} & 7 & 41 & 16 & 5 & \multirow{2}{*}{ مدير ات المدارس الثانوية. } & \multirow{2}{*}{6} \\
\hline & & & 10.9 & 64.1 & 25 & $\%$ & & \\
\hline \multirow{2}{*}{8} & 0701 & & 15 & 33 & 16 & 5) & ضعف معايير اختيار مديرة المدرسة & \\
\hline & 0.701 & 2.01 & 23.4 & 51.6 & 25 & $\%$ & الثانوية. & 7 \\
\hline & & & 9 & 41 & 14 & S & قلة قدرة المديرة على تحليل العمل & \\
\hline 7 & 0.599 & 2.07 & 14.1 & 64.1 & 21.9 & $\%$ & 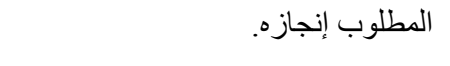 & 8 \\
\hline & & & 12 & 40 & 12 & 5) & تدني مهارة المديرة في توظيف & \\
\hline 9 & 0.617 & 2 & 18.8 & 62.5 & 18.8 & $\%$ & المدرسي. & 9 \\
\hline 10 & $0<00$ & 100 & 13 & 39 & 12 & 5) & قلة عدد سنوات الخبرة لمديرة المدرسة & 10 \\
\hline 10 & 0.629 & 1.98 & 20.3 & 60.9 & 18.8 & $\%$ & الثانوية في مجال العمل الإداري. & 10 \\
\hline & & & 20 & 27 & 17 & 5) & تداخل مهام وصلاحيات مديرة المدرسة & \\
\hline 11 & 0.764 & 1.95 & 31.3 & 42.2 & 26.6 & $\%$ & الثانويةو المشرفة التربوية & 11 \\
\hline 1 & 0612 & 14 & 8 & 39 & 17 & ك & ضعف المهار ات الحاسوبية لدى بعض & \\
\hline 4 & 0.613 & 2.14 & 12.5 & 60.9 & 26.6 & $\%$ & مدير ات المدارس الثانوية. & 12 \\
\hline & & & (2) & 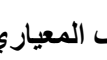 & 11 & ساء. & 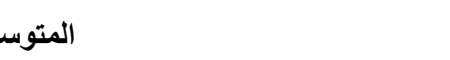 & \\
\hline
\end{tabular}

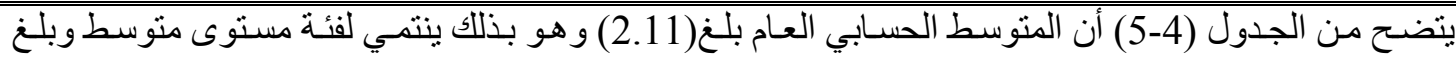

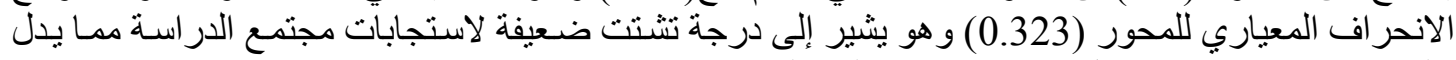

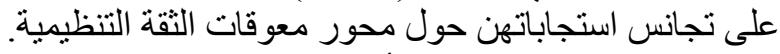

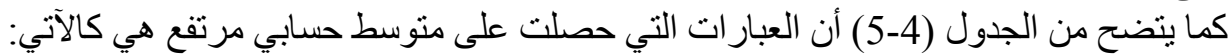

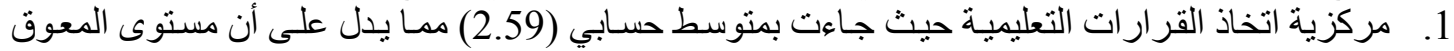
عالي وبانحر اف معياري بلغ (0,555).

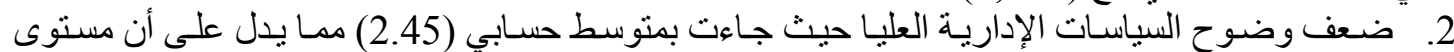
المعوق عالي وبانحر اف معياري بلغ (0.589). 


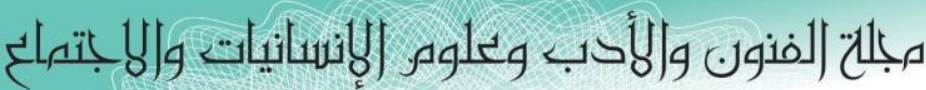

Journal of Arts, Literature, Humanities and Social Sciences

ISSN online: 2414 - 3383

ISSN print: 2616 - 3810

\section{العدد (43) ايلول - سبتمبر 2019}

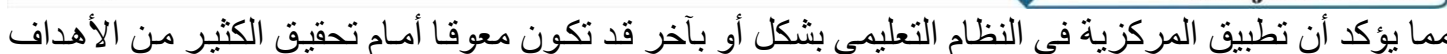

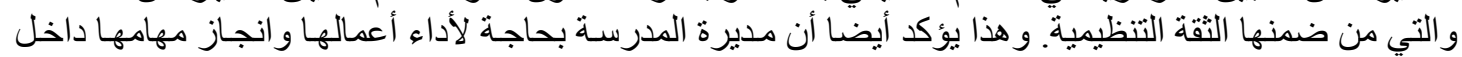

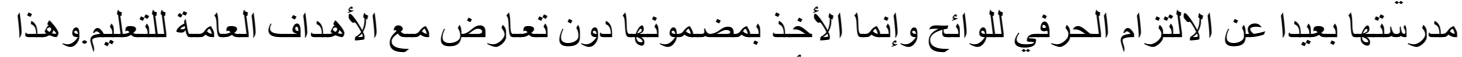

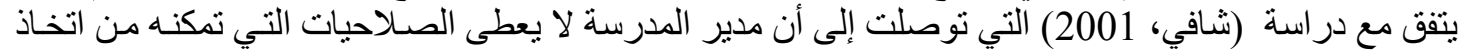

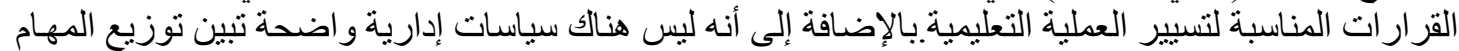

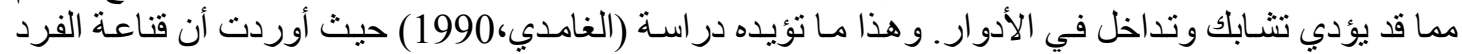

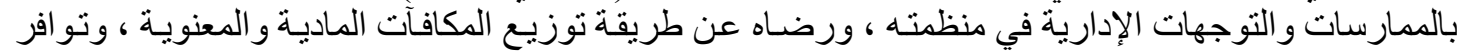

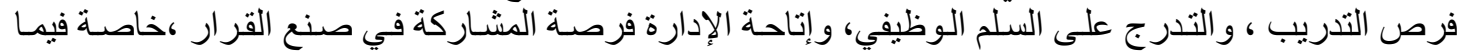

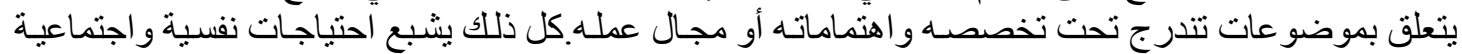
و اقتصادية للموظف ويؤثر إيجابا بثقته بمنظمته وبسياساتها الإدارية.

كما يتضح من الجدول (4-5) أ العبار ات التي حصلت على متوسط حسابي منخفض هي كالآتي:

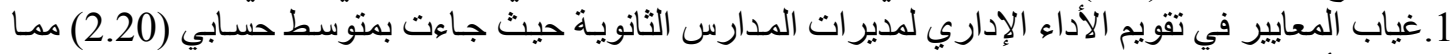

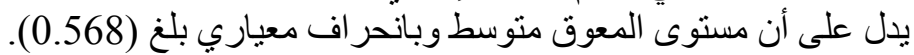

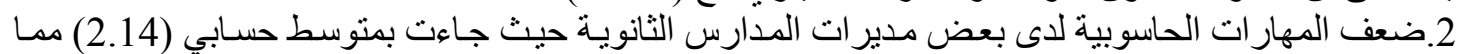
يدل على أن مستوى المعوق متوسط وبانحر اف معيار الفي بلغ (0.613).

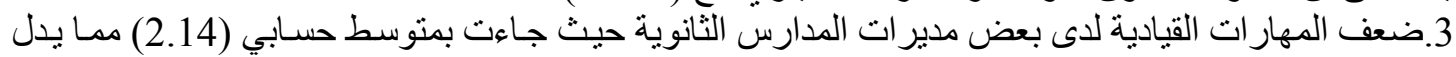
على أن مستوى المعوق متوسط وبانحر اف معياري بلغ الت الفي (0.587).

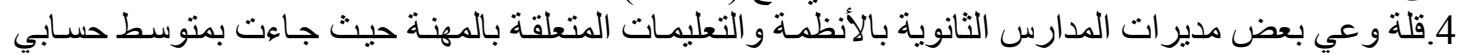

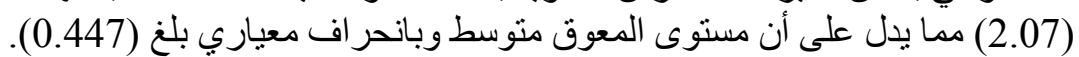

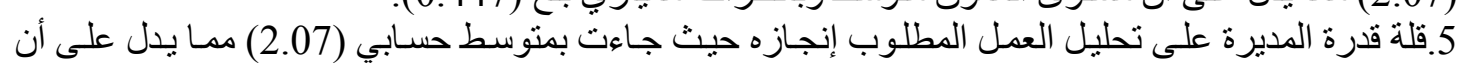

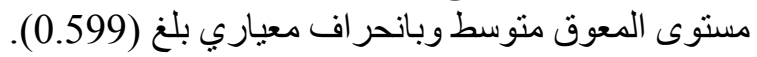

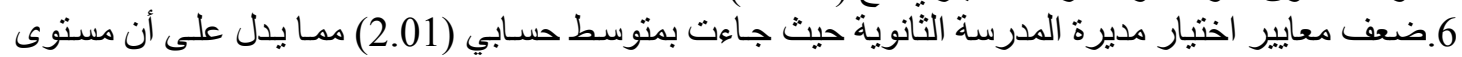

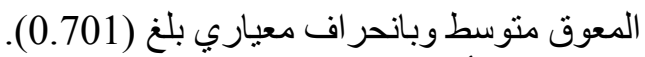

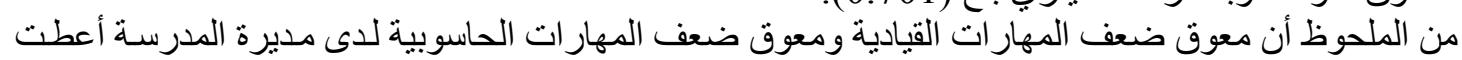

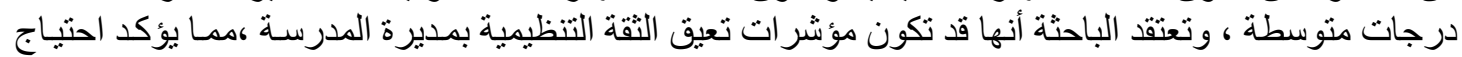

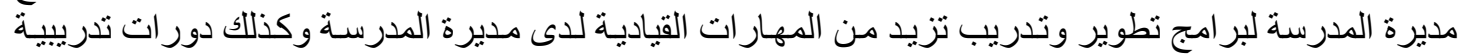

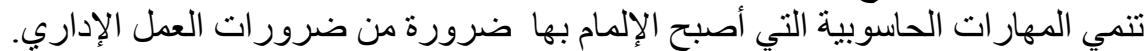

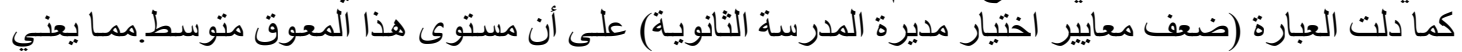

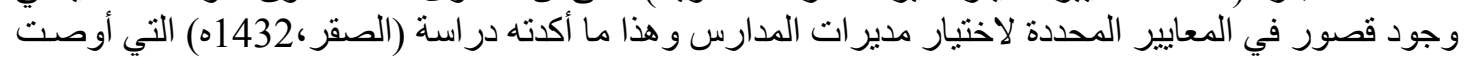

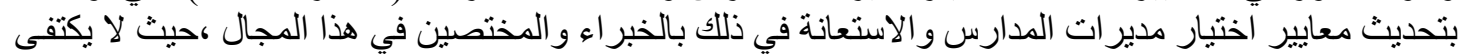

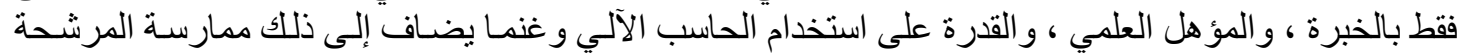

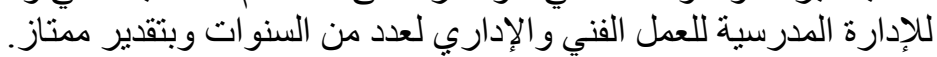

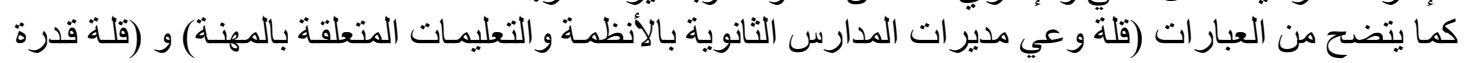

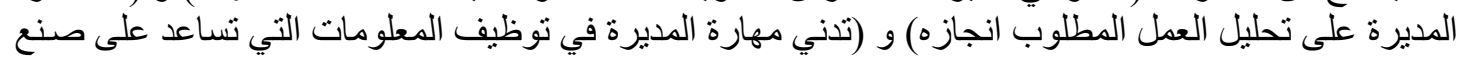

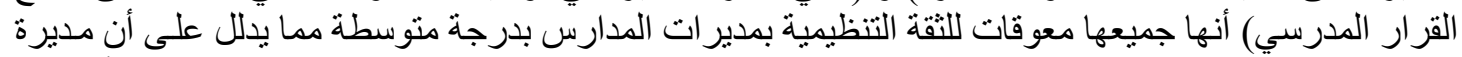

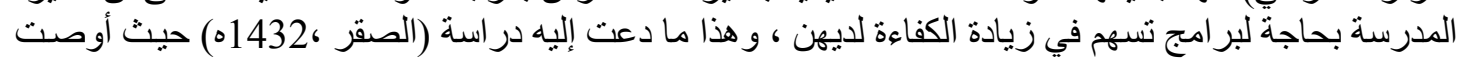

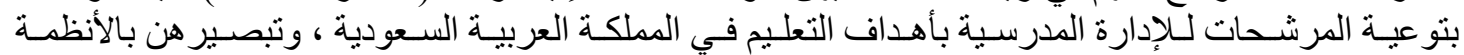

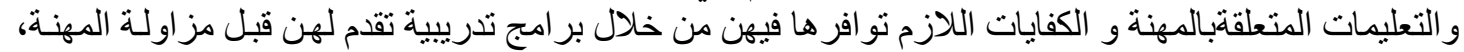

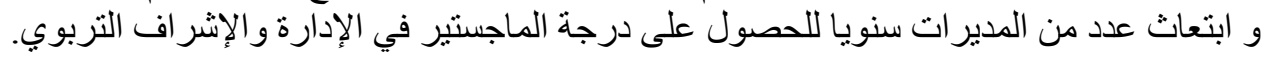

الإجابة على السؤال الثالث:"ما متطلبات تعزيز الثقة التنظيمية بمديرات المدارس الثانوية؟" وللإجابة على هذا

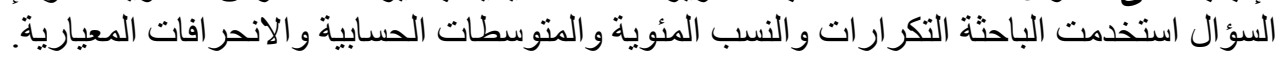




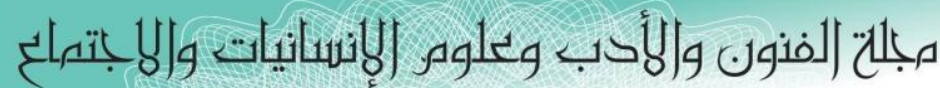

Journal of Arts, Literature, Humanities and Social Sciences

ISSN online: 2414 - 3383

ISSN print: 2616 - 3810

\section{أيلول - سبتمبر 2019}

العدد (43)

جدول (6-4) يبين رأي مجتمع الدراسة حول متطلبات تغزيز الثقة التنظيمية بمديرات المدارس الثانوية

\begin{tabular}{|c|c|c|c|c|c|c|c|c|}
\hline \multirow{2}{*}{ 雪: } & \multirow{2}{*}{ 高哥. } & \multirow{2}{*}{ 裏 } & \multicolumn{3}{|c|}{ درجة الأهمية } & \multirow{2}{*}{\multicolumn{2}{|c|}{ العبارة }} & \multirow[b]{2}{*}{ p } \\
\hline & & & 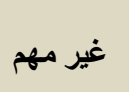 & الاهموسطة & ههم & & & \\
\hline \multirow{2}{*}{1} & \multirow{2}{*}{0} & \multirow{2}{*}{3} & 0 & 0 & 64 & s & \multirow{2}{*}{ تالقرارة الدرسة الثانوية في عملية صنع } & \multirow{2}{*}{1} \\
\hline & & & 0 & 0 & 100 & $\%$ & & \\
\hline \multirow{2}{*}{11} & \multirow{2}{*}{0.407} & \multirow{2}{*}{2.84} & 1 & 8 & 55 & ك & \multirow{2}{*}{ الالاتجاه نحو اللامركزية في إدارات } & \multirow{2}{*}{2} \\
\hline & & & 1.6 & 12.5 & 85.9 & $\%$ & & \\
\hline \multirow{2}{*}{ ק7 } & \multirow{2}{*}{0.213} & \multirow{2}{*}{2.95} & 0 & 3 & 61 & ك & \multirow{2}{*}{ 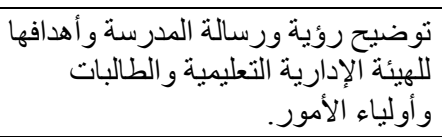 } & \multirow{2}{*}{3} \\
\hline & & & 0 & 4.7 & 95.3 & $\%$ & & \\
\hline \multirow{2}{*}{2} & \multirow{2}{*}{0.125} & \multirow{2}{*}{2.98} & 0 & 1 & 63 & ك & \multirow{2}{*}{ 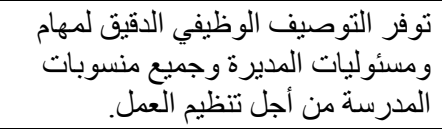 } & \multirow{2}{*}{4} \\
\hline & & & 0 & 1.6 & 98.4 & $\%$ & & \\
\hline \multirow{2}{*}{$3^{3}$} & \multirow{2}{*}{0.175} & \multirow{2}{*}{2.96} & 0 & 2 & 62 & ك & \multirow{2}{*}{ 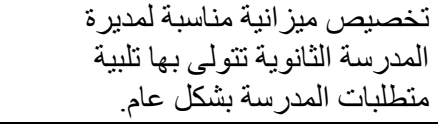 } & \multirow{2}{*}{5} \\
\hline & & & 0 & 3.1 & 96.6 & $\%$ & & \\
\hline \multirow{2}{*}{$3_{p}$} & 0175 & & 0 & 2 & 62 & ك & تنمية الدهارات القيادية لدى مديرة & 6 \\
\hline & $0.1 / 2$ & 2.96 & 0 & 3.1 & 96.6 & $\%$ & المدرسة. & 6 \\
\hline 10 & 0.270 & & 0 & 5 & 59 & ك & تحديد آلية واضحة لعملية اختيار & \\
\hline & 0.2710 & 2.92 & 0 & 7.8 & 92.2 & $\%$ & مدير"ات "الدارس الثانوية. . & 7 \\
\hline 3 & 0175 & 206 & 0 & 2 & 62 & ك & إلماحم مديرة المدرسة الثانوية بالأساليب & 8 \\
\hline $3 p$ & $0.1 / 2$ & 2.96 & 0 & 3.1 & 96.9 & $\%$ & علإلها الإقشر افي بالمدرسة. & 8 \\
\hline & & & 0 & 2 & 62 & s & عمل دورات تدريبية لديرات الددارس & 9 \\
\hline $3 p$ & 0.175 & 2.96 & 0 & 3.1 & 96.9 & $\%$ & تنمي مهارات الحوار لديهن. & 9 \\
\hline 7a & 0213 & 295 & 0 & 3 & 61 & ك & عمل دورات تدريبية لتنمية المهارات & \\
\hline 18 & 0.213 & 2.93 & 0 & 4.7 & 95.3 & $\%$ & ثانوية. & 10 \\
\hline 9 & 0.243 & 2.93 & 0 & 4 & 60 & s & 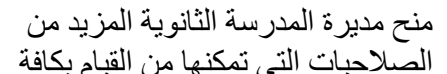 & 11 \\
\hline & & & 0 & 6.3 & 93.8 & $\%$ & أعمالها دون الرجوع عإدارة التُطليم. & \\
\hline & & & العام & اف & $5=$ & & 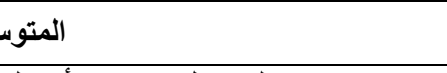 & \\
\hline
\end{tabular}

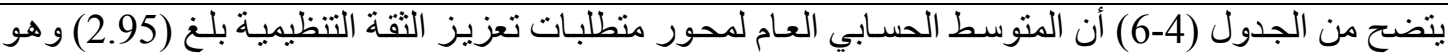

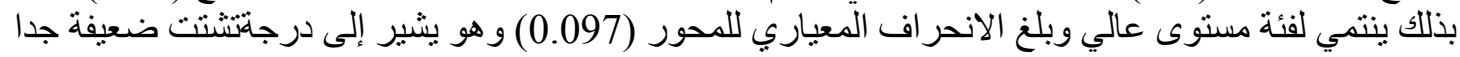

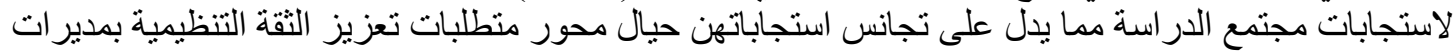
المارس الثانوية. كما يتضح من الجدول أن جميع العبار ات حصلت على متوسط حسابي مرتفع وهي كالآتي: 


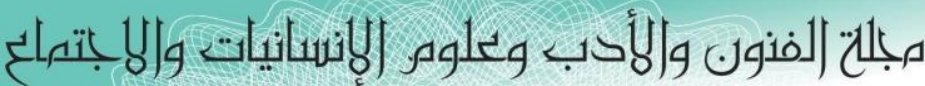

Journal of Arts, Literature, Humanities and Social Sciences

ISSN online: 2414 - 3383

ISSN print: 2616 - 3810

\section{العدد (43) ايلول - سبتمبر 2019}

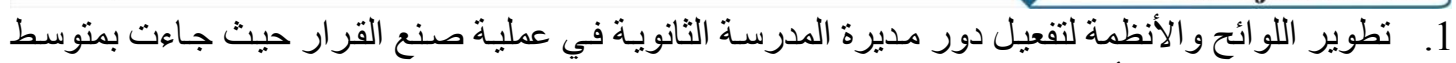

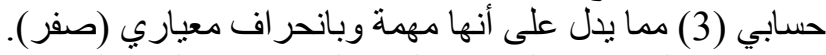

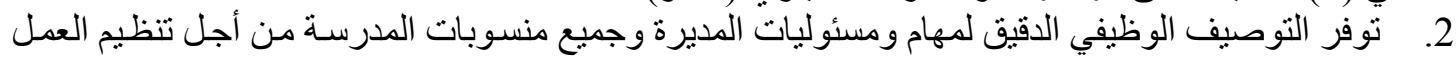

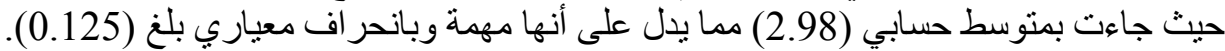

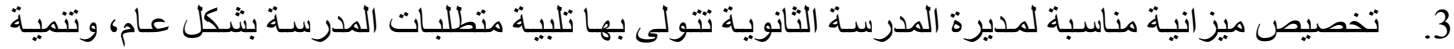

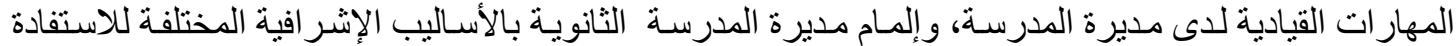

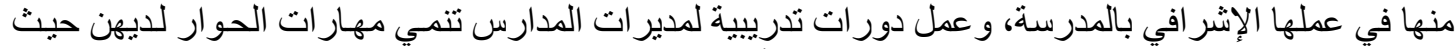

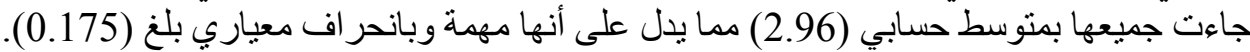

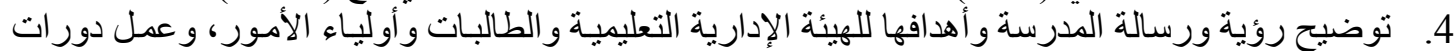

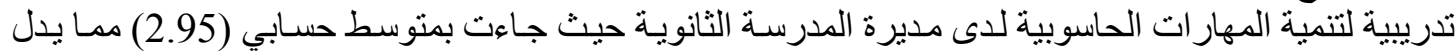

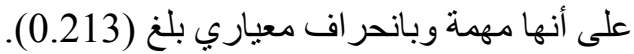

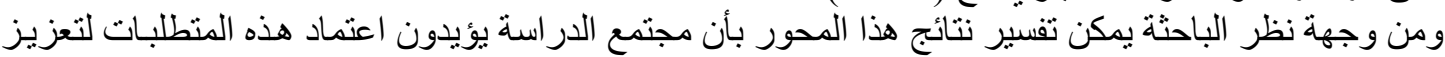

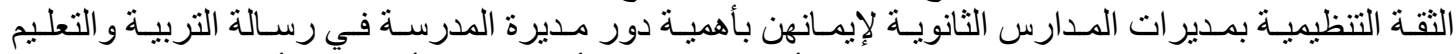

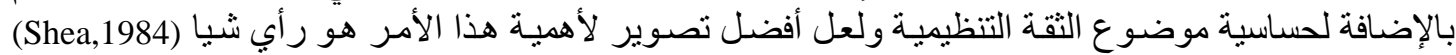

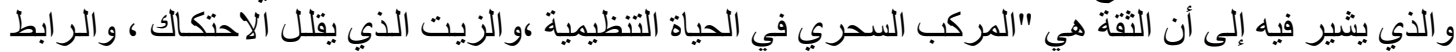

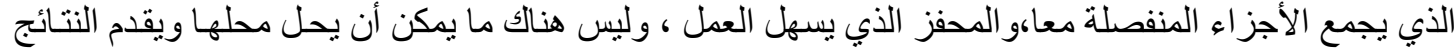

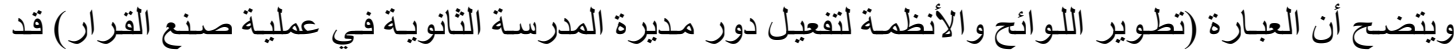

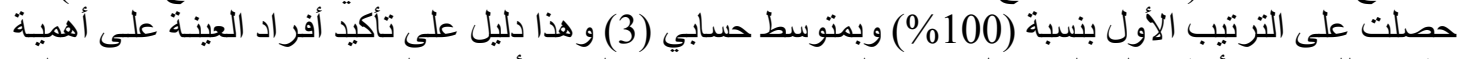

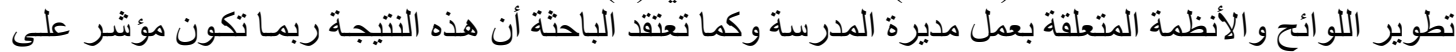

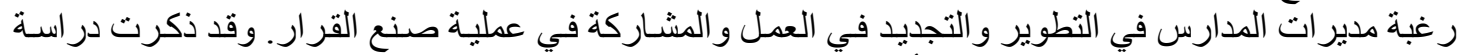

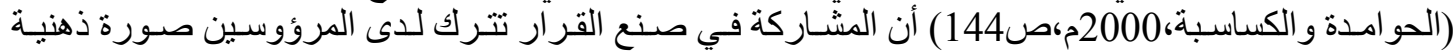

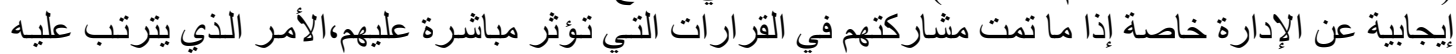

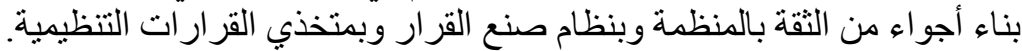

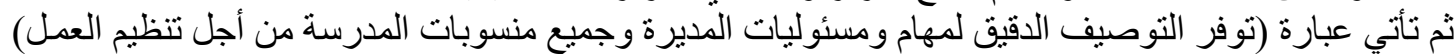

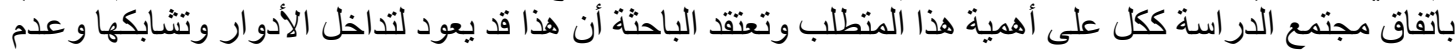

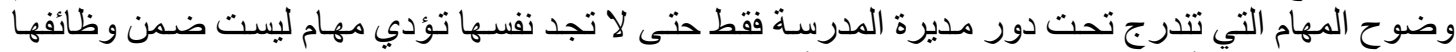

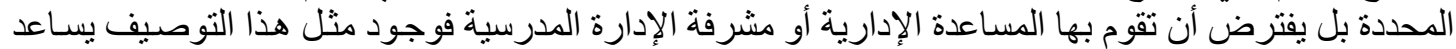

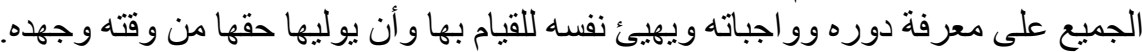

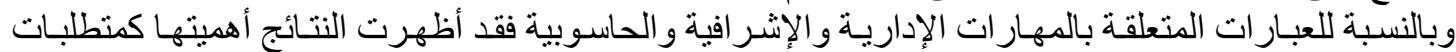

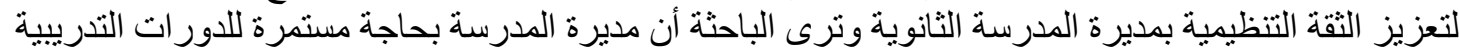

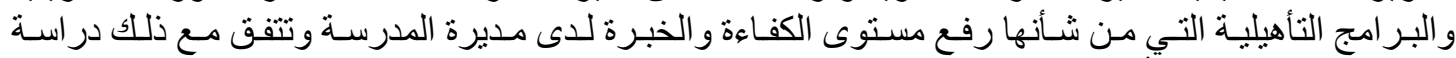

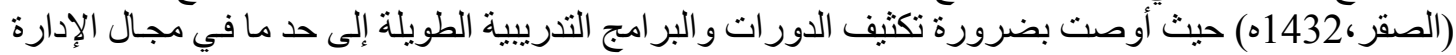

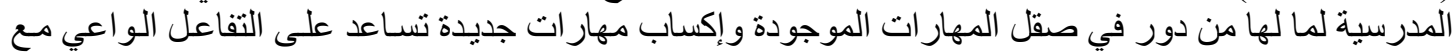
مستجدات العصر في مجال الإدارة المدرسية. وحصلت عبارة (تحديد آلية واضحة لعملية اختيار مدير الآدات المدارس الثانويـة) على متوسط حسابي بلغ (2,92)

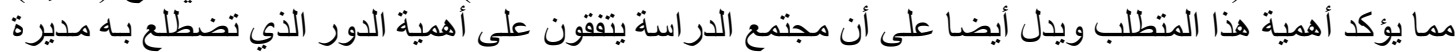

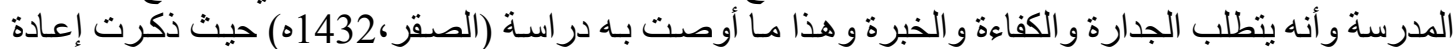

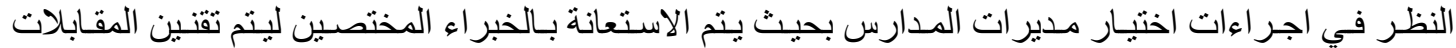
الشخصية و اختبار ات القبول.

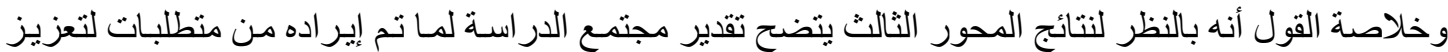

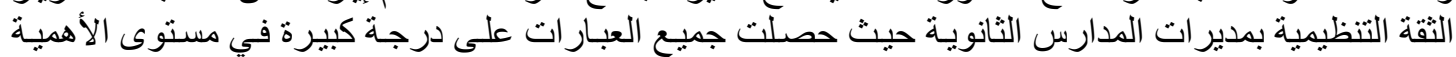

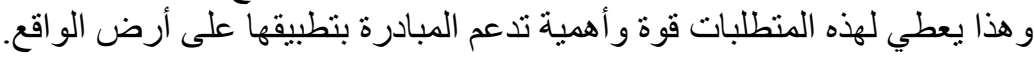




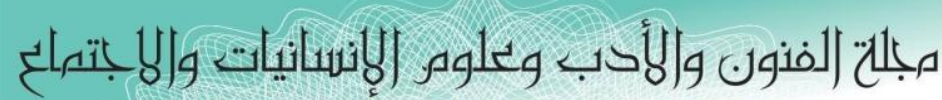
Journal of Arts, Literature, Humanities and Social Sciences

ISSN online: 2414 - 3383

ISSN print: 2616 - 3810

\section{العدد (43) ايلول - سبتمبر 2019}

الإجابة على السؤال الرابع: هل توجد فروق ذات دلالـة احصائية بين استجابات مجتمع الاراسـة حول محاور

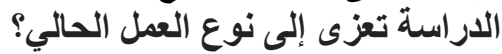

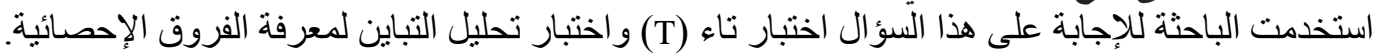

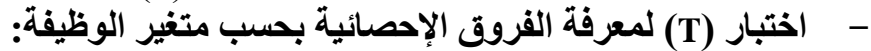
جدول (7-4) يوضح اختبار (T) لبيان الفروق بين الاحين إجابات أفراد العينة بحسب متغير الوظيفة

\begin{tabular}{|c|c|c|c|c|c|c|}
\hline الإحصائية & قيمة T & درجة الحرية & الالمعراف & الحستوسطي & الوظيفة & البيان \\
\hline \multirow{2}{*}{$* 0.009$} & \multirow{2}{*}{$2.724-$} & \multirow{2}{*}{62} & 0.453 & 2.06 & مشرفة & \multirow{2}{*}{ المحور الأول(أولاً) } \\
\hline & & & 0.437 & 2.38 & مديرة & \\
\hline \multirow{2}{*}{$* 0.016$} & \multirow{2}{*}{$2.473-$} & \multirow{2}{*}{62} & 0.369 & 2.16 & مشرفة & \multirow{2}{*}{ المحور الأول(ثانياً) } \\
\hline & & & 0.496 & 2.45 & مديرة & \\
\hline \multirow{2}{*}{0.121} & \multirow{2}{*}{$1.571-$} & \multirow{2}{*}{62} & 0.402 & 2.01 & مشرفة & \multirow{2}{*}{ المحور الأول(ثالثاً) } \\
\hline & & & 0.499 & 2.19 & مديرة & \\
\hline \multirow{2}{*}{0.217} & \multirow{2}{*}{$1.248-$} & \multirow{2}{*}{62} & 0.254 & 2.10 & مشرفة & \multirow{2}{*}{ المحور الأول(رابعاً) } \\
\hline & & & 0.481 & 2.23 & مديرة & \\
\hline \multirow{2}{*}{0.290} & \multirow{2}{*}{$1.067-$} & \multirow{2}{*}{62} & 0.222 & 2.06 & مشرفة & \multirow{2}{*}{ المحور الثاني } \\
\hline & & & 0.373 & 2.15 & مديرة & \\
\hline \multirow{2}{*}{0.308} & \multirow{2}{*}{1.027} & \multirow{2}{*}{62} & 0.073 & 2.96 & مشرفة & \multirow{2}{*}{ المحور الثالث } \\
\hline & & & 0.109 & 2.94 & مديرة & \\
\hline
\end{tabular}

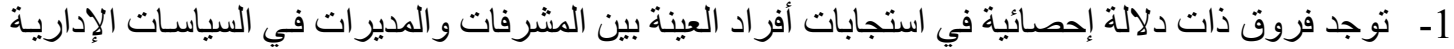

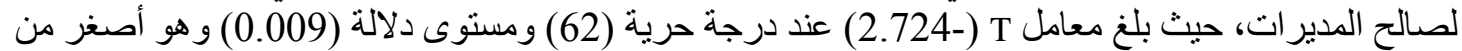

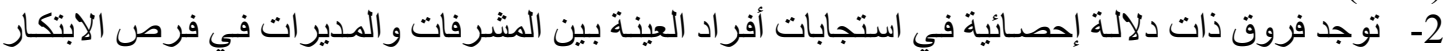

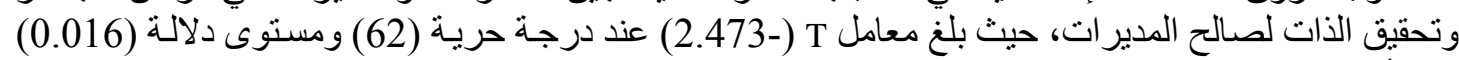

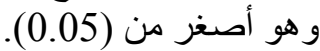

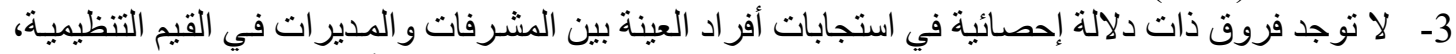

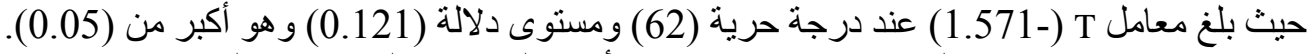

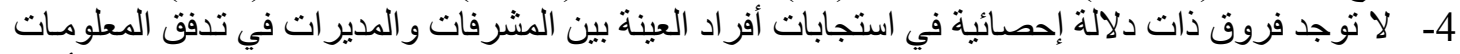
في القنوات التنظيمية، حيث بلغ معامل T (-1.248) عند درجة حرية (62) ومستوى دلاتلة (0.217) وهو أكبر فير

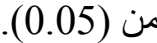
5- لا توجد فروق ذات دلالة إحصائية في استجابات أفر اد العينة بين المشرفات و المدير ات في معوقات الثقاتية

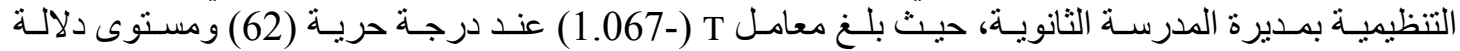
(0.290) وهو أكبر من (0.05). 6- لا توجد فروق ذات دلالة إحصائية في استجابات أفراد العينة بين المشرفات والمديرات في متطلبات تعزيز

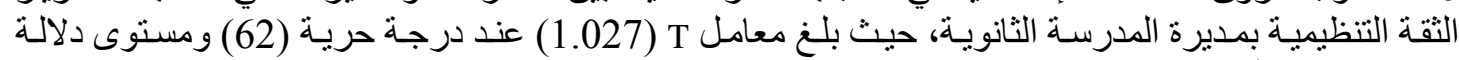

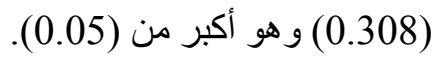

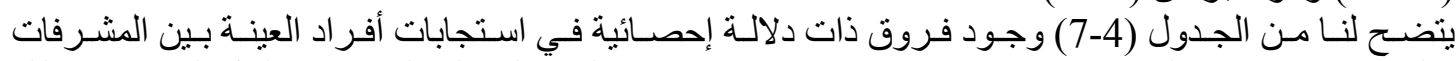

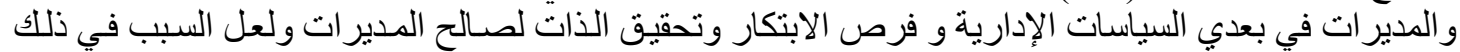
يعود لأنهن الفئة الأغلب في عينة الدراسة.

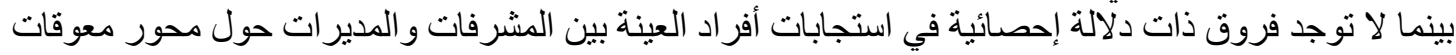

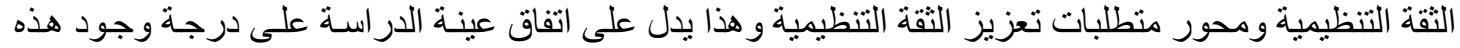




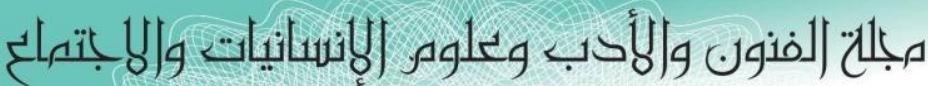

Journal of Arts, Literature, Humanities and Social Sciences

ISSN online: 2414 - 3383

ISSN print: 2616 - 3810

\section{العدد (43) أيلول - سبتمبر 2019}

CALHSS

www.jalhss.com

المعوقات التي تعيق تفعيل دور مدير ات المدارس الثانوية، كما تؤكد اتفاق أفر اد العينة على متطلبـات تعزيز الثقة

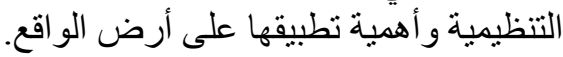

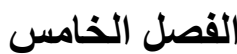 \\ ملخص البحث وعرض النتائج والتوصيات}

1-5 خلاصة الدراسة

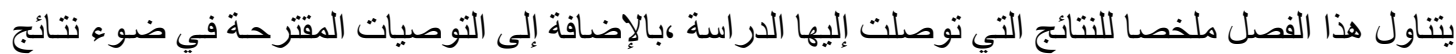

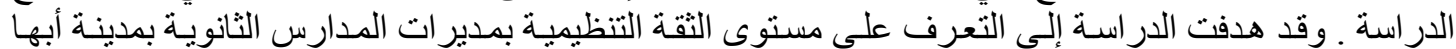

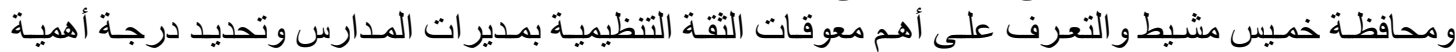

منطلبات تعزيز الثقة التنظيمية بمدير ات المدارس ـ وقد تطلب تحديد تللك الأهداف الإجابة على الأسئلة التالية :

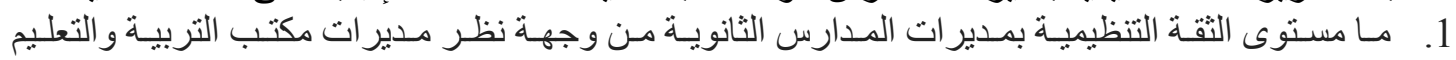

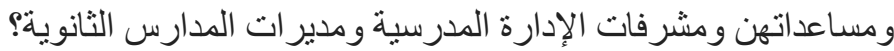

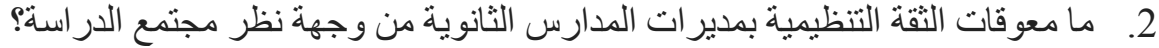

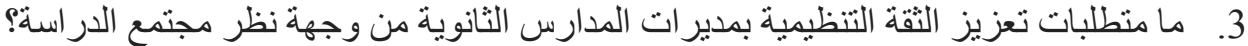

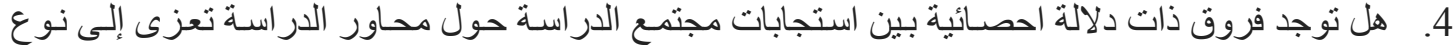

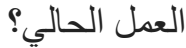
وتكون مجتمع الدر اسة من: مدير ات الإشر اف التربوي ، ومسـاعداتهن، ومشرفات الإدارة المدرسية ، ومدير ات المدارس الثانوية بمدينة أبها ومحافظة خميس التيس مشيط.

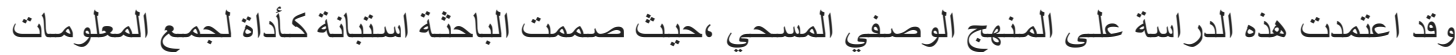

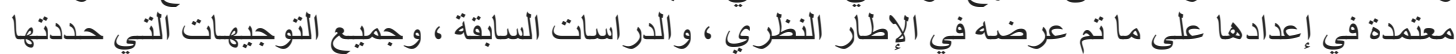
لها المشرفة في البناء الأولي للاستبانة ، وتكونت الاستبانة من ثلاثثة محاور رئيسية ،و هي: المحور الأول:مستوى الثقة التنظيمية بمدير ات المدارس الثانوية ويندرج تحته أربعة أبعاد للثقة التنظيمية. المحور الثاني: معوقات الثقة التنظيمية بمدير ات المدارس الثنانوية. المحور الثالث:أهم منطلبات تعزيز الثقة التنظيمية بمديرات المدارس الثانية الثية.

وقد تم جمع البيانات ثم تفريغها ، ثم معالجتها إحصائيا باستخدام برنامج (spss) و فقا للأساليب التالية:

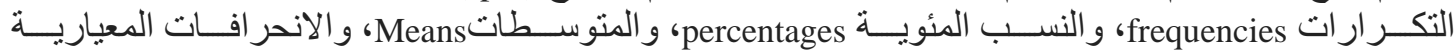
Alpha Pearson Correlation Coefficient ومعات Peviation Cronpach. و اشتملت الدر اسة بصورتها النهائية على خمسة فصول رئيسة ، بالإضافة إلى قائمة المر اجع، وملاحق الدراسة.

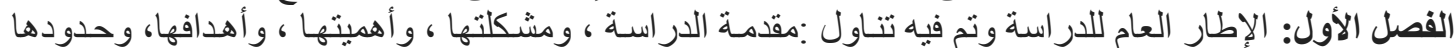

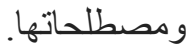

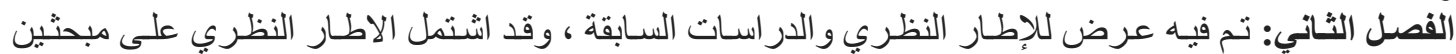

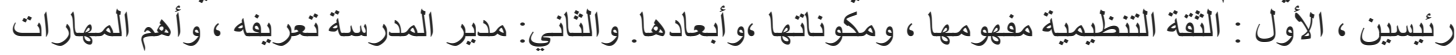

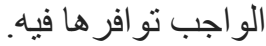

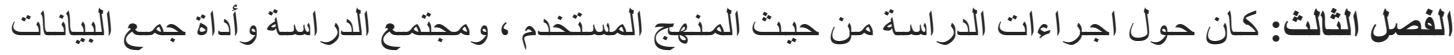

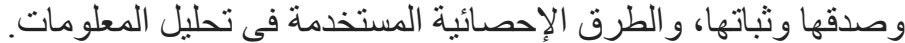

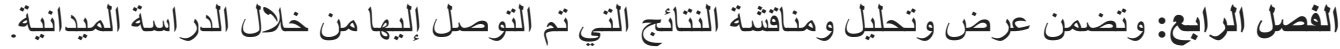

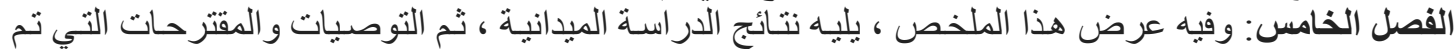
التوصل إلبها من خلال نتائج الدر اسة. 


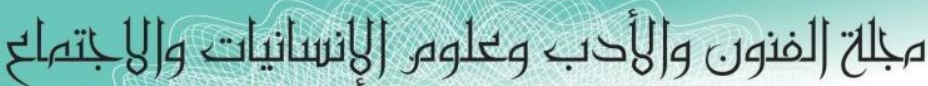

Journal of Arts, Literature, Humanities and Social Sciences

ISSN online: 2414 - 3383

ISSN print: 2616 - 3810

\section{العدد (43) ايلول - سبتمبر 2019}

اظهرت نتائج التحليل الإحصـائي للار اسـة الميدانيـة عددا من النتائج المهمة ويمكن عرض ملخص للنتائج فيما المحائ الأول: مستوى الثقة التنظيمية بمديرات المدارس الثانوية .

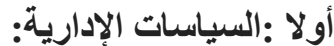

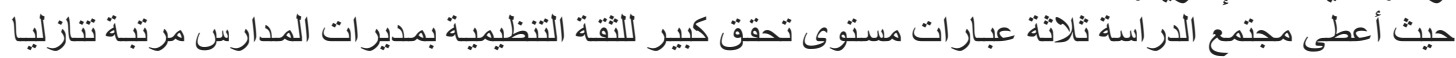

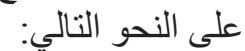

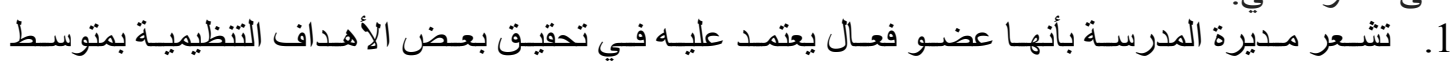

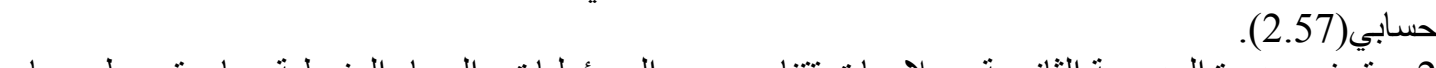

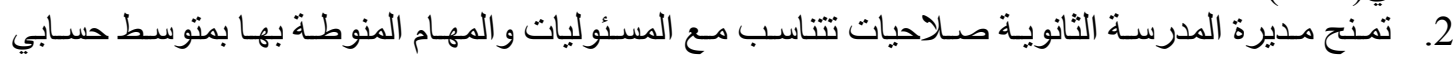

3. يتم تفويض مديرة المدرسة ببعض الصلاحيات في حال غياب المشرفة التربوية بمتوسط حسابي (2.34).

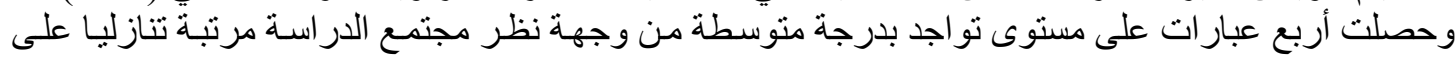

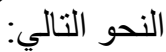
1. تحدد مديرة المدرسة احتياجات المدرسة المادية و البشرية وتتخذ التدابير و الإجر اءات اللازمـة مع الجهات المعنية ويوفر لها ذللك بمتوسط حسابي (2.29).

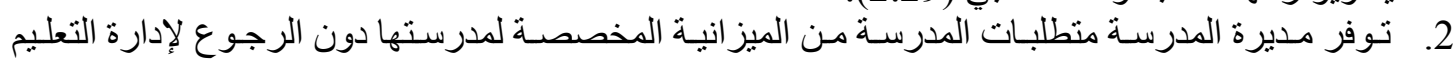
بمتوسط حسابي (2.26). 3. تشارك مديرة المدرسة الثانوية في صنع بعض القرار ات المهمة لسبر العملية التربويـة و التعليميـة بمتوسط حسابي (2.23). 4. يوجد نظسام حفز عـادل مرتبط بـالأداء و الخبرات والقدر ات و الجهود التي تبذلها مديرة المدرسـة بمتوسط

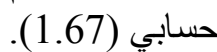
ثانيا: فرص الابتكار وتحقيق الذات:

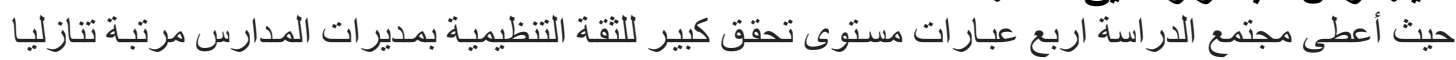

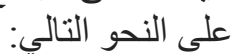
1. تمثلك مديرة المدرسـة الثانويـة الجر أة على تفويض الصـلاحيات والمهام في العمل عنها بمنوسط حسابي

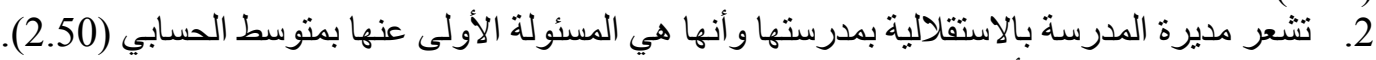

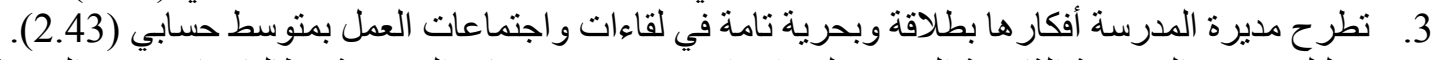

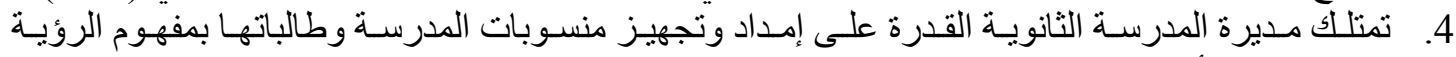

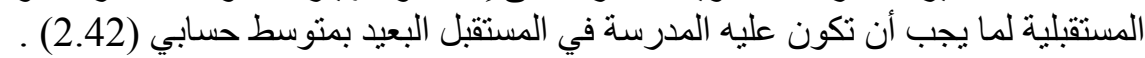

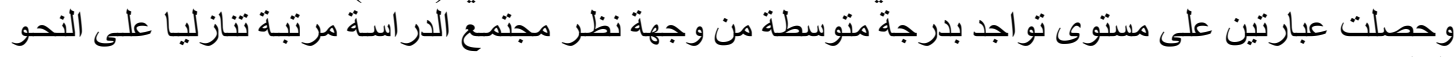

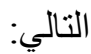
1. تحصدل مديرة المدرسة الثانوية على قدر من السلطات و المهام التي تمكنها من ممارسـة دور هـا في الابتكار و التجديد في العمل دون الرجوع لإدارة التعليم بمنوسط حسابي (2.14).

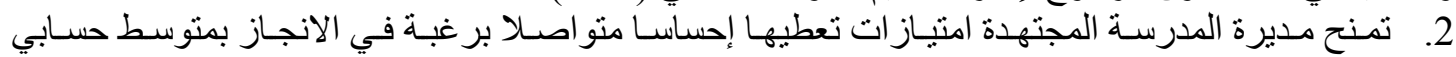

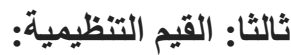

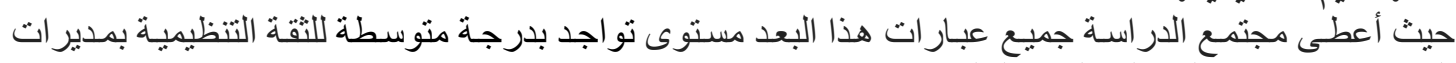
المدارس مرتبة تنازليا على النحو التالي:

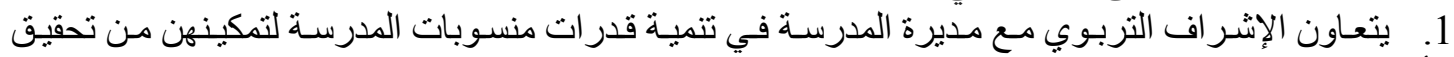
الأهداف المرجوة بمنوسط حسابي (2.32). 


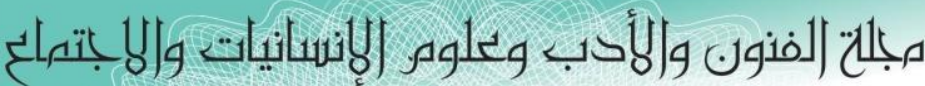

Journal of Arts, Literature, Humanities and Social Sciences

ISSN online: 2414 - 3383

ISSN print: 2616 - 3810

\section{العدد (43) ايلول - سبتمبر 2019}

2. تُتعر مديرة المدرسة أن هناك من يثق بقدرتها على إنجاز العمل دون رقابة بمتوسط حسابي (2.31).

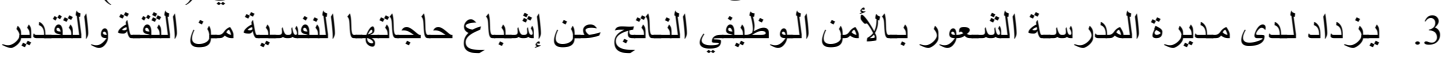

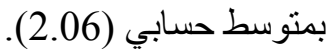

4. ت تستشعر مديرة المدرسة الثانوية روح العدالة و الإنصاف في التعامل معها بمتوسط حسابي (2.01).

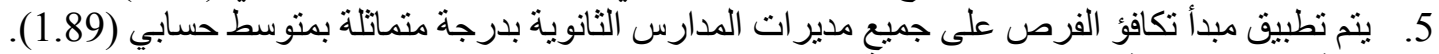
رابعا:تثفق المعلومات في القتوات التنظيمية:

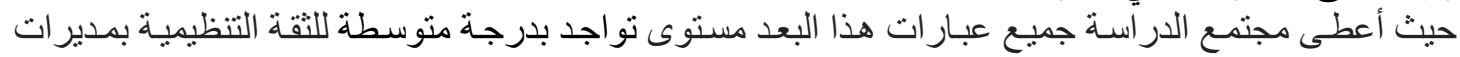

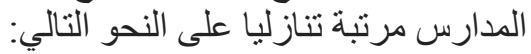

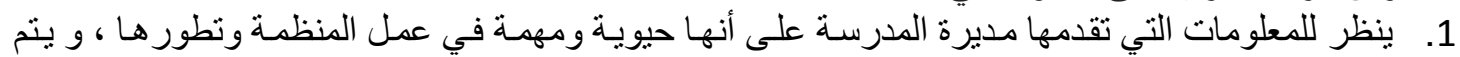

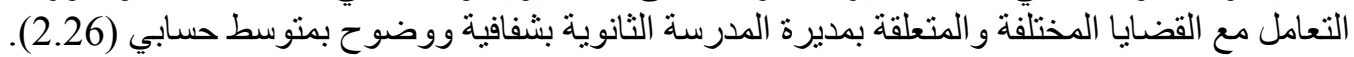
2. ت تقوم علاقات مديرة الددرسة الثانوية على الانفتاح الداخلي و الخارجي محع البيئة التنظيمية بمنوسط حسابي

3. ت تتذفق المعلومات في جميع الاتجاهات بشكل يساعد مديرة المدرسة الثانوية في اتخاذ القرار ات دون تشويه أو تحريف بمنو سط حسابي (2.14). 4. تزود مديرة المدرسة الثانوية بالمعلومات الثـاملة و الدقيقة التي تحتاجها بالوقت المناسب بمتوسط حسابي

5. تشعر مديرة المدرسة بضعف الاتصـال بالإدارات العليا ممـا يجعلها تتستر على الشكلات التي تواجهها. بمتوسط حسابي (2.07).

المحور الثاني:معوقات الثقة التنظيمية بمديرات المدارس الثانوية. حيث أعطى مجتمع الدراسة عبارتين مستوى تحقق كبير لمعوق الثقة التنظيمية بمدير ات المدارس مرتبة تنازليا

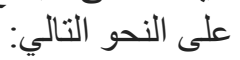
1. مركزية اتخاذ القرارات التعليمية بمتوسط حسابي (2.59).

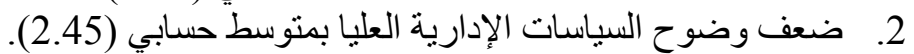
كما أعطى مجتمع الدراسة عشرة عبار التيات مستوى نو اجد متوسط لمعوق الثقة التنظيمية بمدير ات المدارس مرتبة تنازليا على النحو التالي: 1. غباب المعايير في تقويم الأداء الإداري لمدير اتل المدارس الثانوية بمتوسط حسابي (2.20). 2.

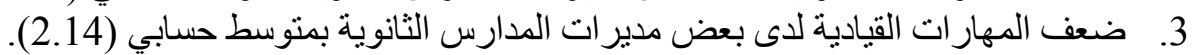

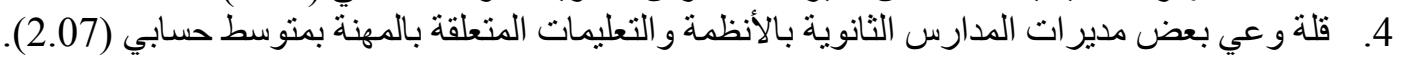

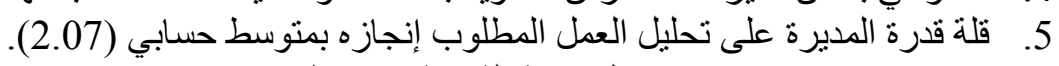
6. . ضعف معايير اختبار مديرة الددرسة الثانوية بمتوسط حسابي (2.01).

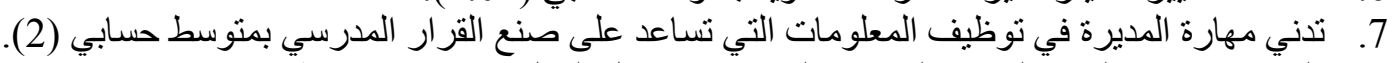

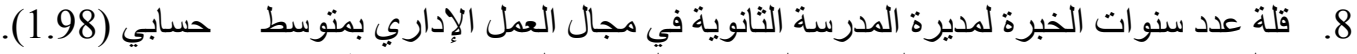

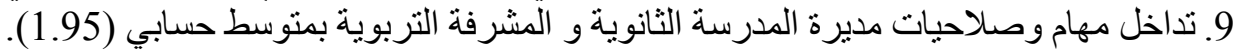

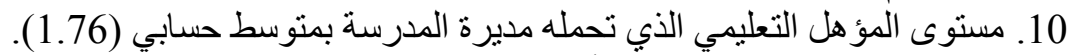

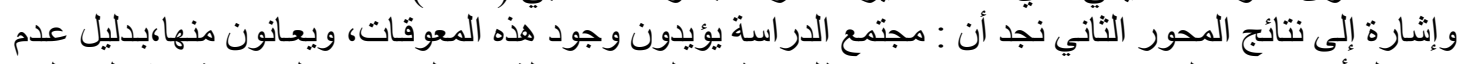

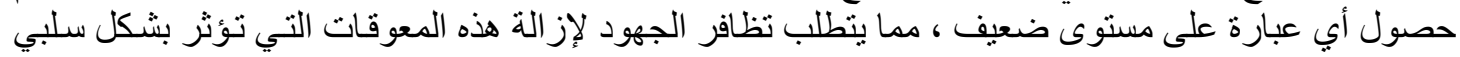

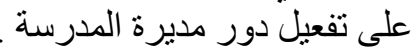

المحور الثالث: متطبات تعزيز الثقة التنظيمية بمديرات المدارس الثانوية.

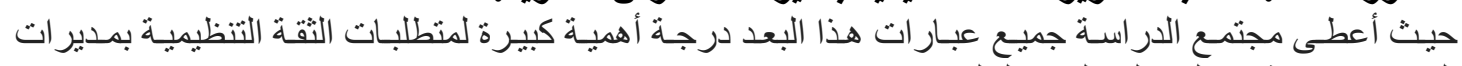

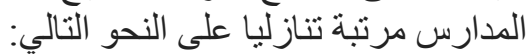

1. تطوير اللو ائح والأنظمة لتفعيل دور مديرة المدرسة الثانوية في عملية صنع القرار بمتوسط حسابي (3). 


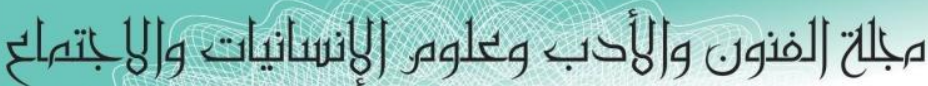

Journal of Arts, Literature, Humanities and Social Sciences

ISSN online: 2414 - 3383

ISSN print: 2616 - 3810

\section{أيلول - سبتمبر 2019}

العدد (43)

2. ت توفر التوصيف الوظيفي الدقيق لمهام ومسئوليات المديرة وجميع منسوبات المدرسة من أجل تنظيم العمل

بمتوسط حسابي (2.98).

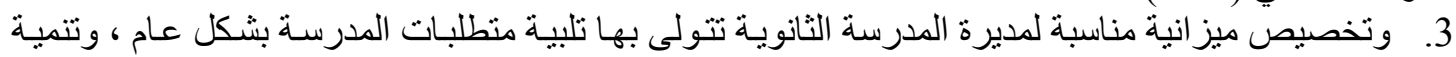

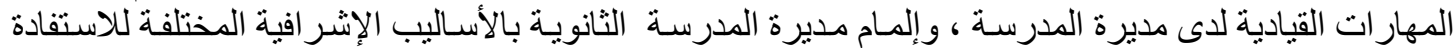

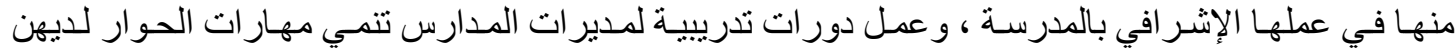
بمتوسط حسابي (2.96). 4. توضيح رؤية ورسالة المدرسة و أهدافها للهيئة الإدارية التعليمية والطالبات وأولياء الأمور، و عمل دورات

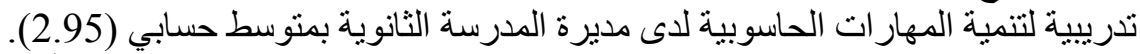

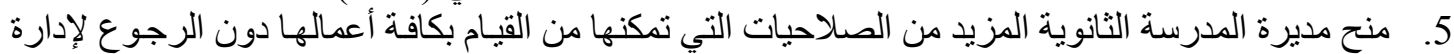
التعليم بمنتو سط حسابي (2.93).

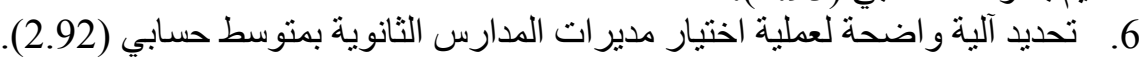
7.

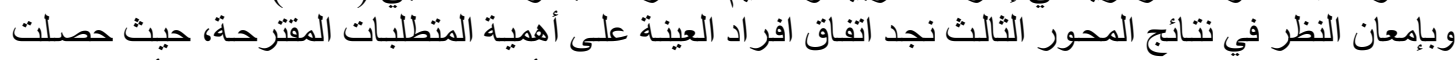

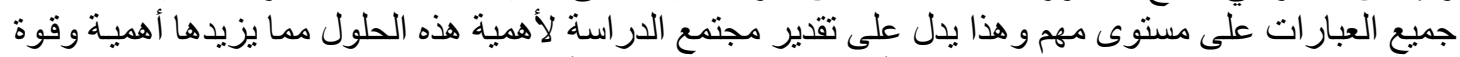

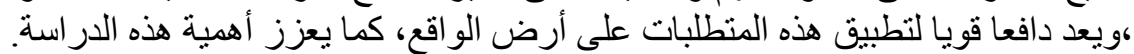

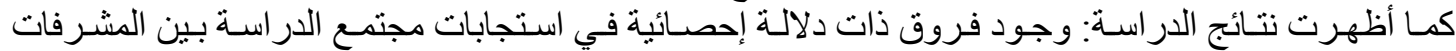

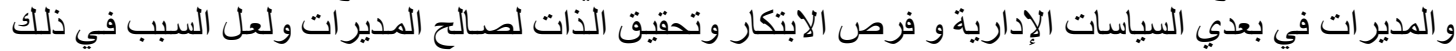
يعود لأنهن الفئة الأظلب في عينة الدراسة.

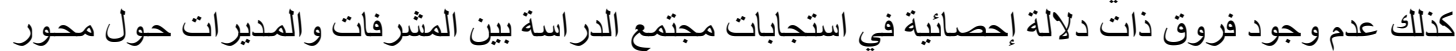

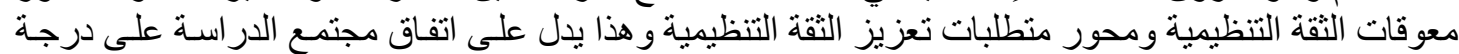

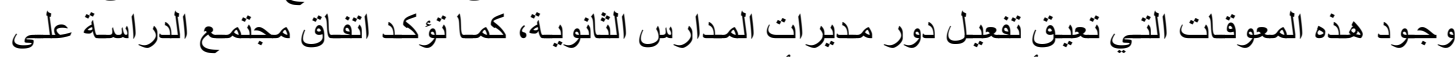

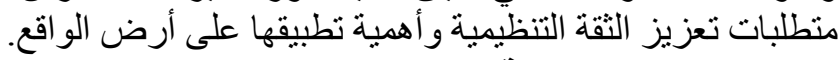
3-5 توصيات الدراسة في ضوء النتائج التي توصلت إليها الدراسة فإن الباحثة توصي بمـا يلي لرفع مستوى الثقة التنظيمية بمديرات

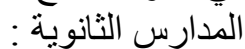
1. المبادرة بتفعيل جميع الصـاحيات الممنوحسة لديرة المدرسـة والبـالغ عددها 52 صـلاحية لتصبح مهيأة لاللتطبيق على أرض الو اقع. 2. تطبيق نظام حفز عادل مرتبط بالأداء و الجهود التي تبذلها مديرة المدرسة و الخبرات والقدرات التي تمتلكها. 3. تحديث معايير اختيار مديرات المدارس الثانوية وإعادة النظر في إجراءات الترشيح بحيث ينت الاستعانة بالخبر اءو والمختصين.

4. الختح المجال أمام مديرة المدرسة لتطبيق ما لديها من أفكار ابداعية تسهم في التطوير و التجديد بمدرستها.

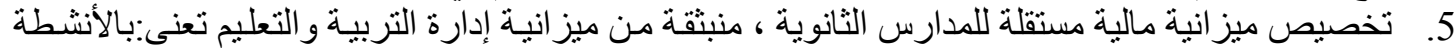

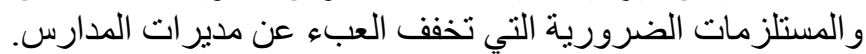

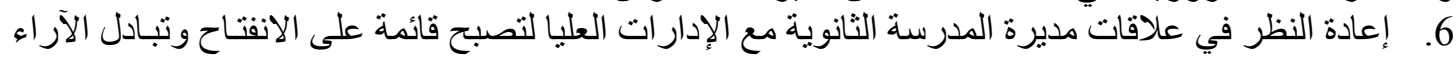
مما يزيد قوة الاتصال وتوفير المعلومات اللازمة لكلا الطرفير الطين. 7. ت تكثيف الدور اتصات التنرييية لمدير ات المدارس الثانوية في مجال المهار ات الإدارية ومهارات الحوار وفن القيادة.

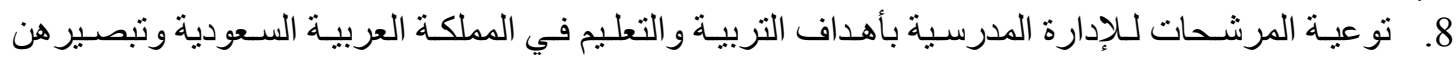

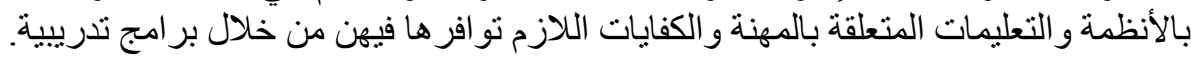

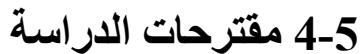
1. 2. إجر اء دراسة مماثلة على قطاع البنين. 


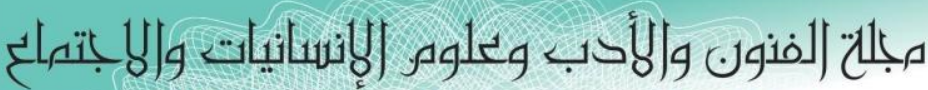

Journal of Arts, Literature, Humanities and Social Sciences

ISSN online: 2414 - 3383

ISSN print: 2616 - 3810

\section{العدد (43) ايلول - سبتمبر 2019}

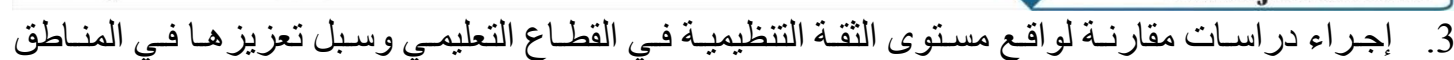
التعليمية المختلفة بالمملكة العربية السعودية وبعض دون الدون الدول العربية و الأجنبية.

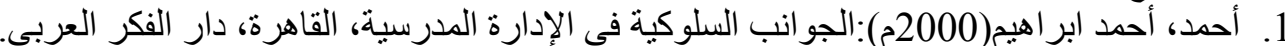

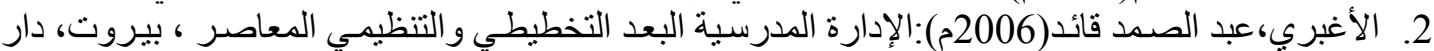

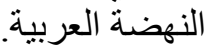

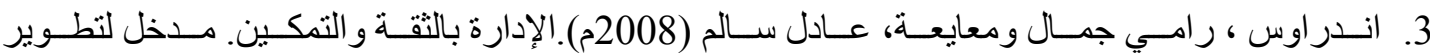

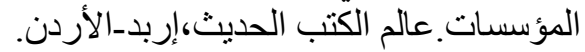

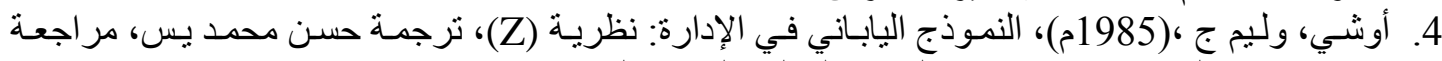

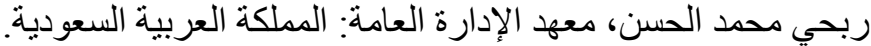

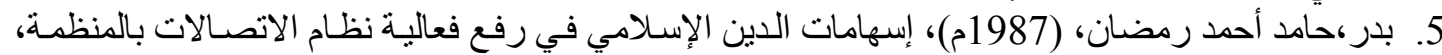

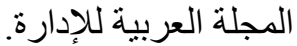

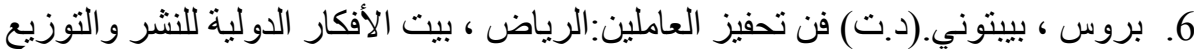

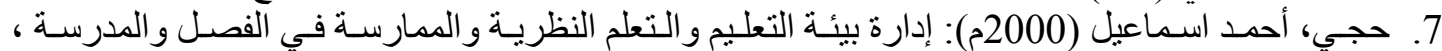
2005) 2005): الإدارة التعليميــــة والإدارة المدرســـية، القاهرة ، دار الفكر العربي. القاهرة، دار الفكر العربي. 9. حريم، حسن (2010م): مبادئ الإدارة الحديثة. النظريات، العمليات الإدارية، وظـائف المنظمـة. عمـان، دار الحامد للنشر و التوزيع.

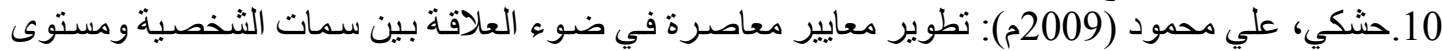

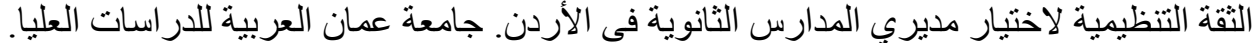

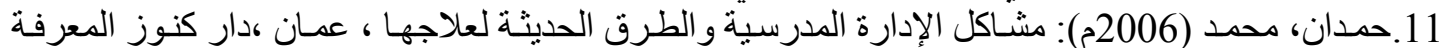
للنشر و التوزيع.

12.الحو امدة،نضال و الكساسبة،محمد (2000م). أثر الثقة التنظيمية و المشـاركة في صنع القرار ات على على رضـا

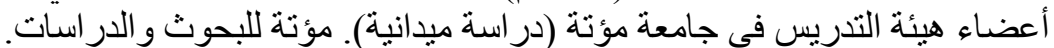

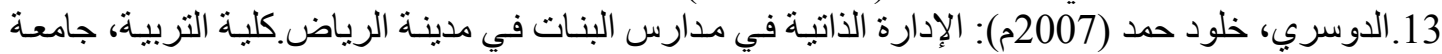

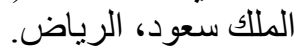
14.الديري، عبير عبداله (1426ه): الثقة التظظيميـة للرؤسـاء بالمر عوسـات في الوحدات الإداريـة النسـائية في

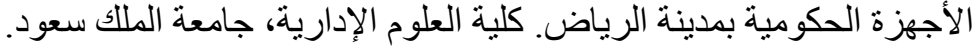

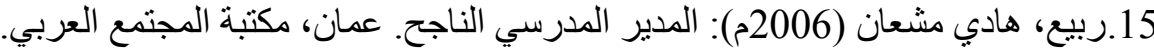

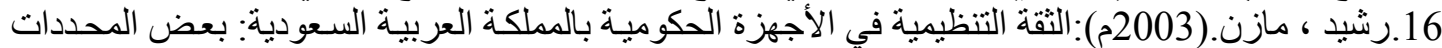
و الآثار . الإدارة العامة. 17.روثبرج، روبرت. (1989م): إنماءالتقةه المهارة القيادية المنسية. (ترجمة عادل ياسين). التربية، س(1)،ع ع

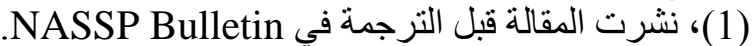

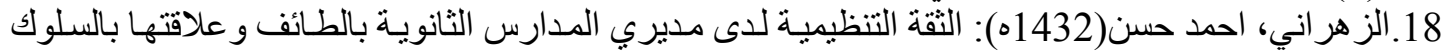

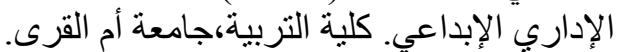

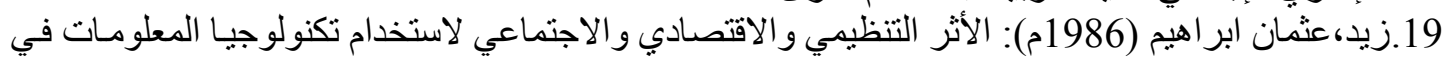

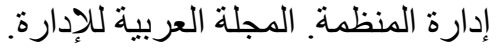
20.سليمان، مؤيد سعيد(1987م): المناخ التنظيمي: مفهوم حديث في الفكر الإداري المعارية المعاصر ، المجلة العربيـة لإِدارة. 21.سيد، أسامه محمد (2009م): الإدارة الذاتية للمدرسة، كفر الثيخ. العلم والإيمان للنشر والتوزيع. 


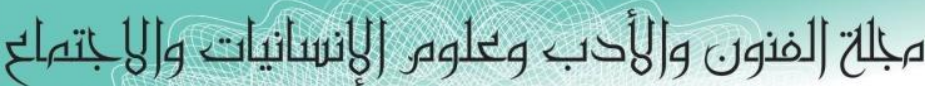

Journal of Arts, Literature, Humanities and Social Sciences

ISSN online: 2414 - 3383

ISSN print: 2616 - 3810

\section{العدد (43) ايلول - سبتمبر 2019}

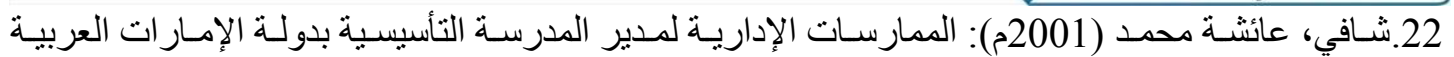

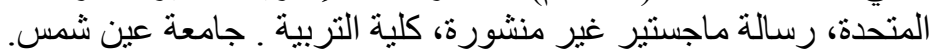

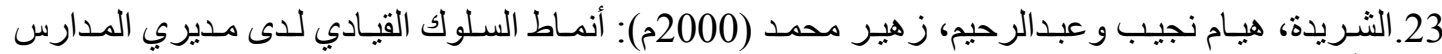

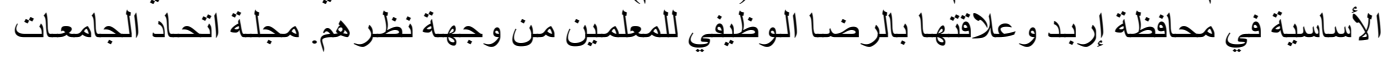

العربية.

24.الثقير ات، محمود طافش (2004م): الإبداع في الإشر اف التربوي و الإدارة المدرسية، إربد. دار الفرقان.

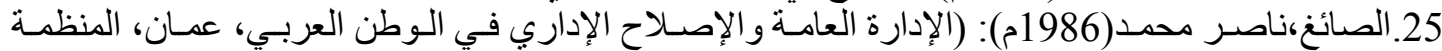
العربية للعلوم الإدارية.

26.الصباغ ، زهير .(1986م).من الإدارة بالتخويف إلى الإدارة بالثقة.الإدارة العامة، الرياض ، المملكة العربية

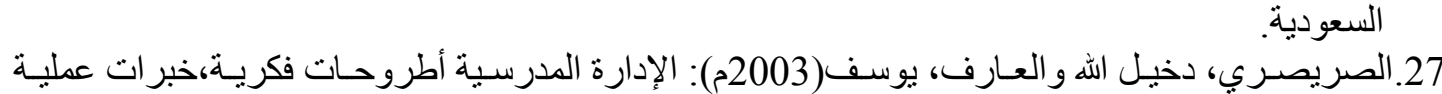

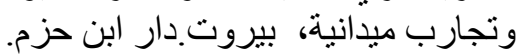

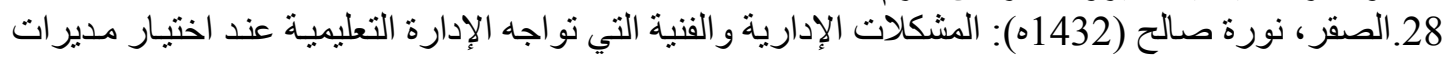

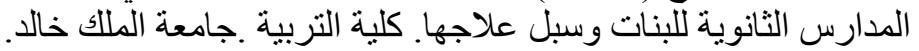

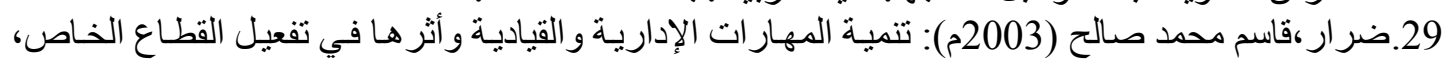
الرياض. مكتبة الملك فهد الوطنية. 30. عبيدات، ذوقـان وآخرون (2004م): البحـث العلمي مفهومه/أدو اتـه/ أسـاليبه، الريـاض. دار أسـامه للنشـر

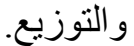

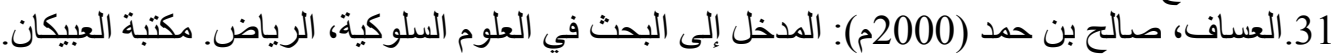

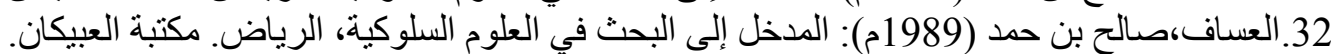

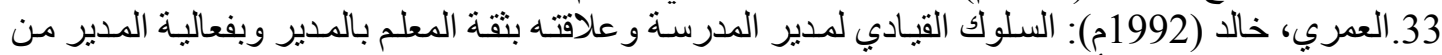

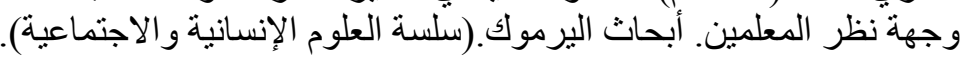

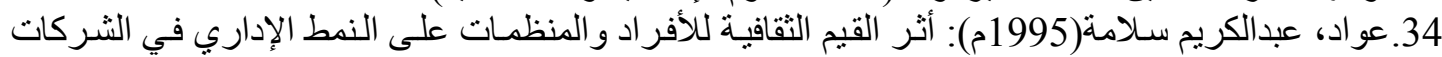

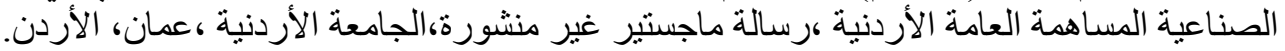

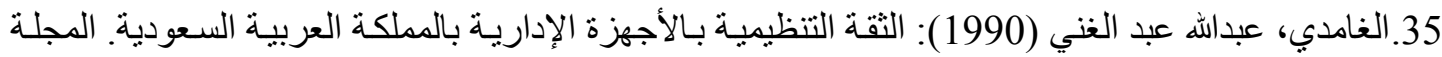

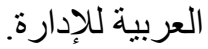

36.الفضلي ، صباح.(1999).العلاقة بين العائد المتوقع على الأداء الفعال ومجمو عـة من المتغير ات.در اسـات

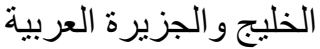

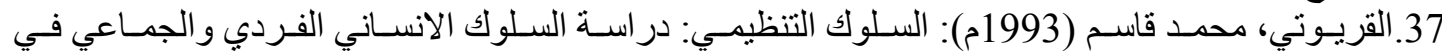

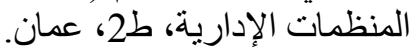

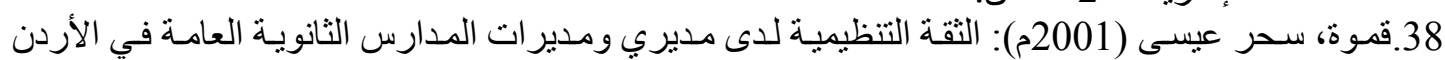

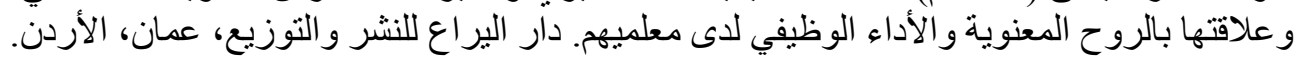

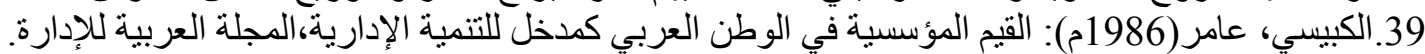

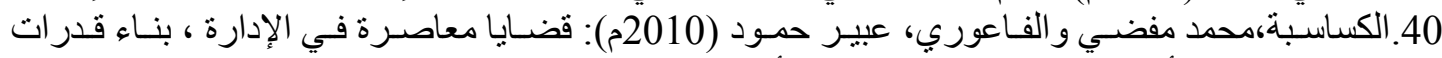

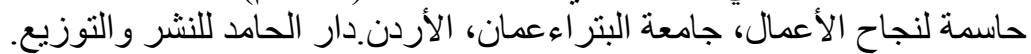

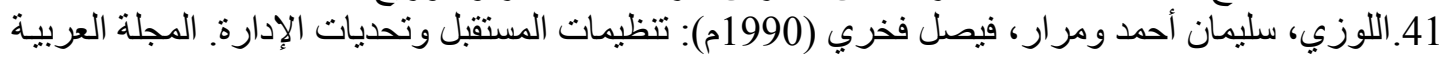
لـ للإدارة.

42.المسعودي، مسلم سليم (2006م): معايير مقترحة لاختيار مديري المدارس في المنطقة الثمالية الغربية

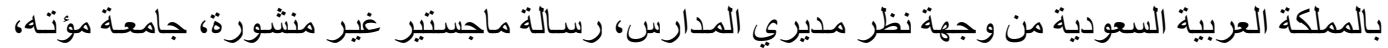

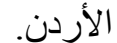
43.المعايطة، عبدالعزيز عطـا الله (2007م): الإدارة المدرسية في ضوء الفكر الإداري المعاصر ،عمان. دار الحامد للنشر و التوزيع. 


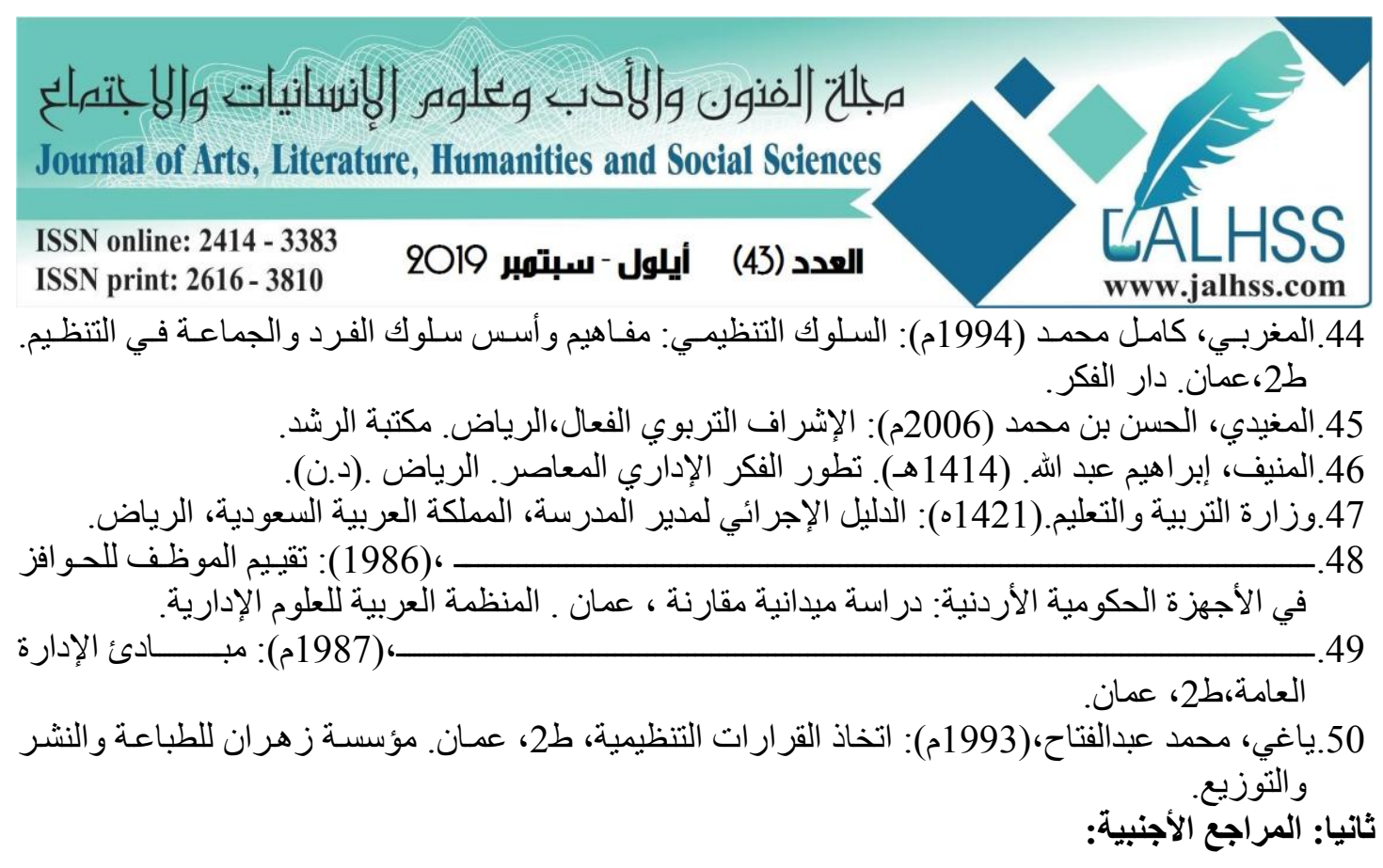

1. Cresap(1990), Foundations for the Future: A focus for the administration of Tasmanian Education and the Arts. Cresaps final report. Sydney: Cresap.

2. Corazzini, G. J., (1977)," Trust as Complex Multi Dimensional Construct". Psychological Reports,75-80.

3. Driscoll, W. J., (1978), "Trust and Participation in Organizational Decision Making as Predictors of Satisfaction", Academy of Management Journal,44-56

4. Daley, Dennis M.; Vasu, Michael L., (1998). "Fostering Organizational Trust in North Calorina: The Pivotal Role of Administration and Political Leaders"

5. Drucker, F. P., (1988) "The Coming of New Organization". Harvard Business Review,January-February,45-53.

6. Eisenberger, R., Huntington, R., Huchinson, S. \& Sowa, D. (1986). Berceived organizational support. Journal of Applied Psychology,71.

7. Gilbert, J.A Tang T.1. (1998). An examination of organizational trust antecedent. Public Personal Management,27(9).

8. Glasman, N.S,(1984) "Student achievement and the school principal", Educational Evaluation and Policy Analysis.

9. Handy, C., (1995) "Trust and The Virtual Organization". Harvard Business Review, May- June:40-50.

10. Lind, E. A. \& Tyler, T.R. (1986). The social psychology of procedural justice. New York: Plenum.

11. Luhmann, N., (1979), Trust and Power, New York: Hon Wiley \& Sons Ltd.

12. Makhamreh, M. and El-Farhan, A., (1990), " Factors Affecting Employee motivation in Jordan", Dirsat,Series A,The Humanities, 17A,(2): 7.

13. Mishra, K(1996). Organizational Responsible to Crises, the Centrality of Trust. In Kramer R Thousands Oaks,sage (1996). Trust in Organization: Fronties of Theory and Research, Thousands Oaks.

14. Moshe,T(1991). A Knowledge Base for Information Technology in Educational Administration. Journal of Research on Computing in Education.

15. Nahavandi, Afsaneh(2003). The art science of leadership, third edition. 


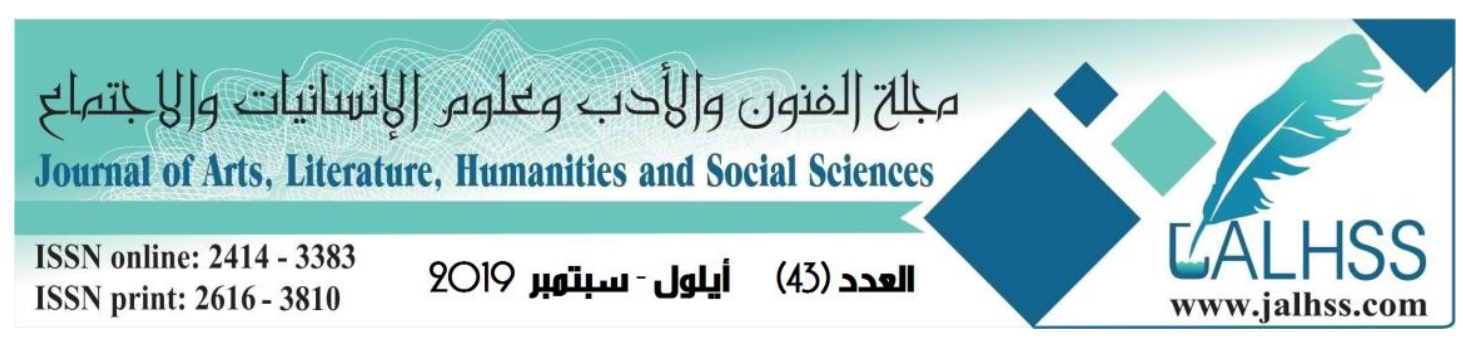

16. Patton, B. B. and Giffin, k.,(1976), Trusting me Trusting you, Columbus, Ohio: A Bell \& Howell Company.

17. Pilli, R.; Williams, E. \& Tan, J. (2001). Are the scales tipped in favor of procedural or distributive justice? An investigation of the U.S. India, Germany and Hong Kong (China). International Journal of Conflict Management,12(4).

18. Purkey, Stewart C and Smith, Marshalls(1983). "Effective Schools. The Elementary school Journal,83 (4).

19. Robbins, P. S., (1993), Organaizational Behavior: Concepts, Controversies and Applications,Sixth Edetion New Jersey: Prentice Hall International, Inc.

20. Shea, G. F. (1984). Building Trust in the Workplace. New York: AMA Membership Puplication Division.

21. Simon H, A, (1976), Administrative Behavior,Third Edetion, New York: Free Press.

22. Tschannen-Moran, Megan \& Hoy, Wayne K. (2000). " A Multidisciplinary Analysis of the Nature, Meaning, and Measurement of Trust", Review of Educational Research, Vol.70 No.4.

23. Whitener,E.M. Brodt, S. E. Korsgaard,M.A \& Werner J. M.(1998). Manager as Initiator of Trust. The Academy of Management Review,23 (3).

24. Zand, D. (1972). Trust and Managerial problem solving. Administrative Science Quarterly.

\section{References}

1. Ahmed, Ahmed Ibrahim (2000): Behavioral Aspects of School Administration, Cairo, Dar Al-Fikr Al-Arabi.

2. Al-Aghbari, Abdul Samad Qaid (2006): School Administration The contemporary planning and organizational dimension, Beirut, Dar Al-Nahda Al-Arabiya.

3. Andraos, Rami Jamal and Maayah, Adel Salem (2008). Introduction to Institutional Development. Modern Book World, Irbid-Jordan.

4. Oshi, William J., (1985), The Japanese Model in Management: Theory (Z), Translated by Hassan Mohammed Yassin, Review of Profitable Mohammed Al-Hassan, Institute of Public Administration: Saudi Arabia.

5. Badr, Hamid Ahmed Ramadan, (1987), the contributions of the Islamic religion in raising the effectiveness of the communication system in the Organization, the Arab Journal of Management.

6. Bruce, Peppton. (D) The art of motivating workers: Riyadh, House of Ideas International for publication and distribution

7. Hajji, Ahmed Ismail (2000): Management of the teaching and learning environment theory and practice in the classroom and school, Cairo, Dar Arab thought.

8. 2005) -): Educational and School Administration,

Cairo, Dar Al Fikr Al Arabi.

9. Harem, Hassan (2010): Principles of Modern Management. Theories, administrative processes, organization functions. Amman, Dar Al - Hamed for Publishing \& Distribution. 


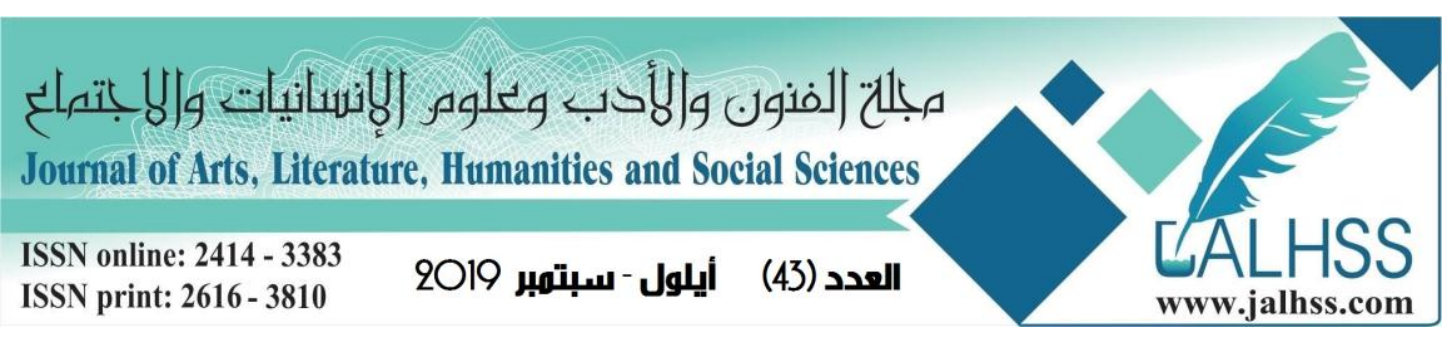

10. Hashki, Ali Mahmoud (2009): Developing contemporary standards in light of the relationship between personality traits and the level of organizational confidence in the selection of secondary school principals in Jordan. Amman Arab University for Graduate Studies.

11. Hamdan, Mohammed (2006): Problems of school management and modern methods of treatment, Amman, Dar treasures of knowledge for publication and distribution.

12. Al-Hawamdeh, Nidal and Al-Kasabeh, Mohammad (2000). The Effect of Organizational Trust and Participation in Decision Making on the Satisfaction of Faculty Members at Mu'tah University (Field Study). Mutah Research and Studies.

13. Al-Dosari, Kholoud Hamad (2007): Self-management in girls' schools in Riyadh, College of Education, King Saud University, Riyadh.

14. Al-Deiri, Abeer Abdullah $(1426 \mathrm{H})$ : Organizational confidence of the heads of female subordinates in the administrative units in the government agencies in Riyadh. College of Administrative Sciences, King Saud University.

15. Rabi, Hadi Mashaan (2006): the successful school director. Amman, Arab Society Library.

16. Rasheed, Mazen (2003): Organizational Trust in Government Agencies in Saudi Arabia: Some Determinants and Impacts. Public Administration.

17. Rothberg, Robert. (1989): Development of confidence - the forgotten leadership skill. (Translation by Adel Yassin). Education, Q (1), GS (1), published article before translation in NASSP Bulletin.

18. Al-Zahrani, Ahmed Hassan (1432H): Organizational trust among secondary school principals in Taif and its relation to creative administrative behavior. Faculty of Education, Umm Al - Qura University.

19. Zaid, Osman Ibrahim (1986): Organizational, economic and social impact of the use of information technology in the management of the organization. Arab Journal of Management. 20. Suleiman, Moayad Saeed (1987): Organizational Climate: A Modern Concept in Contemporary Administrative Thought, Arab Journal of Management.

21. Sayed, Osama Mohamed (2009): School self-management, Kafr El-Sheikh. Science and faith for publication and distribution.

22. Shafi, Aisha Mohammed (2001): Administrative practices of the Principal of the Foundation School in the United Arab Emirates, an unpublished Master Thesis, Faculty of Education. Ain-Shams University.

23. Al-Shraideh, Hiyam Najeeb and Abdul Rahim, Zuhair Mohammad (2000): Patterns of Leadership Behavior among Principals of Primary Schools in Irbid Governorate and their Relationship to Teachers' Job Satisfaction from their Perspective. Journal of the Federation of Arab Universities.

24. Shuqairat, Mahmoud Tafesh (2004): Innovation in Educational Supervision and School Administration, Irbid. House of Criterion.

25. Sayegh, Nasser Mohammed (1986): (Public administration and administrative reform in the Arab world, Amman, Arab Organization for Administrative Sciences.

26. Al-Sabbagh, Zuhair (1986). From Intimidating to Confident Administration. Public Administration, Riyadh, Saudi Arabia.

27. Al-Sraisiri, Dakhil Allah and Al-Aref, Yousef (2003): School Management Theses, Practical Experiences and Field Experiences, Beirut. 


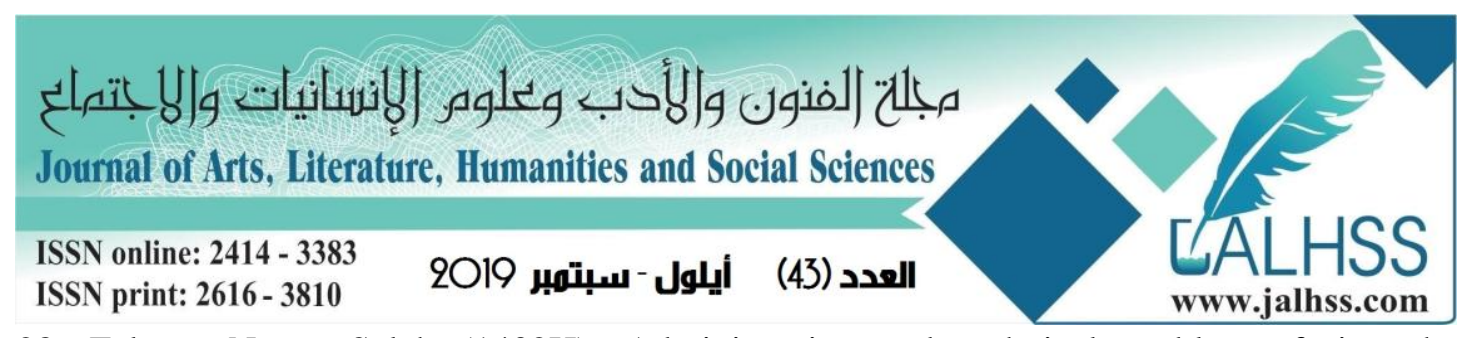

28. Falcon, Noura Saleh $(1432 \mathrm{H})$ : Administrative and technical problems facing the educational administration when selecting secondary school principals for girls and ways of treatment. College of Education, King Khalid University.

29. Dirar, Qasim Mohammed Saleh (2003): Development of management and leadership skills and their impact on the activation of the private sector, Riyadh. King Fahd National Library.

30. Obeidat, Zouqan and others (2004): Scientific research concept / tools / methods, Riyadh. Dar Osama For Publishing \& Distribution.

31. Assaf, Saleh bin Hamad (2000): Introduction to Research in Behavioral Sciences, Riyadh. Obeikan Library.

32. Al-Assaf, Saleh Bin Hamad (1989): Introduction to Research in Behavioral Sciences, Riyadh. Obeikan Library.

33. Al-Omari, Khalid (1992): the leadership behavior of the principal and its relationship with the trust of the teacher and the effectiveness of the principal from the perspective of teachers. Yarmouk Research.

34. Awad, Abdul Karim Salameh (1995): The Impact of Cultural Values of Individuals and Organizations on the Administrative Pattern in the Jordanian Public Joint Stock Companies, Unpublished Master Thesis, University of Jordan, Amman, Jordan.

35. Al-Ghamdi, Abdullah Abdul-Ghani (1990): Organizational confidence in the administrative organs in Saudi Arabia. Arab Journal of Management.

36. Al-Fadhli, Sabah (1999). The relationship between the expected return on effective performance and a set of variables.

37. Al-Qaryouti, Mohammed Qasem (1993): Organizational Behavior: A Study of Individual and Group Human Behavior in Administrative Organizations, 2nd Floor, Amman.

38. Qumwa, Sahar Issa (2001): Organizational confidence in the principals and principals of public secondary schools in Jordan and its relationship to the morale and functionality of their teachers. Firefly Publishing House. 